Linköping Studies in Science and Technology

Dissertations, No. 1635

\title{
Planning production and supply chain in energy intensive process industries
}

\section{Martin Waldemarsson}

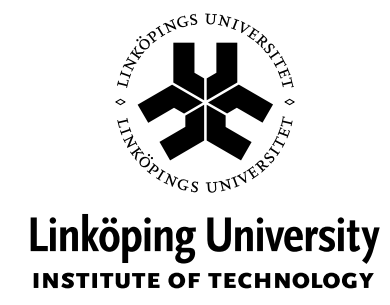

2014

Division of Production Economics

Department of Management and Engineering

Linköping University, SE-581 83 Linköping 
Cover picture: (C) Martin Waldemarsson, 2014

"Planning production and supply chain in energy intensive process industries"

Linköping studies in science and technology, Dissertation, No. 1635

ISBN: 978-91-7519-173-7

ISSN: 0345-7524

Printed by: LiU-Tryck, Linköping

Distributed by:

Linköping University

Department of Management and Engineering

SE-581 83 Linköping, Sweden

Tel: +4613281000 


\begin{abstract}
To make a difference among the energy intensive process industries, this dissertation addresses production planning and supply chain planning problems related to industrial energy management issues. The energy issue is turning more and more important from different angles, involving price as well as environmental problems due to climate change leading to political pressure on all energy users. The process industry sector is one of the largest users of energy, and thus important to analyse. Process industries are also capital intensive and operate on large and expensive process equipment, making it imperative to plan their production well in order to reach preferable capacity utilisation. Therefore this dissertation strives to locate the most important energy management issues for the long term profitability of process industries, and investigates the symbiotic effects of including energy issues in production and supply chain planning.
\end{abstract}

Three different studies at three case companies are carried out, analysed, and presented in five papers. The cases represent the process industry sectors: chemicals, pulp, and steel. Both qualitative case study methodologies as well as quantitative mathematical modelling and optimisation approaches have been practiced. The research questions are analysed from both an energy system and from a production process point of view, separately as well as combined. Energy is somewhat considered to be the main workforce for process industries and this dissertation exemplifies some of its most important dimensions in this context.

Several prerequisites for putting energy management on the strategic agenda are located in a specialty chemical industry where the importance of introducing a strategic perspective on energy, the way energy is used, and the possibilities of increasing alternative revenue from utilising by- and/or co-products differently are pinpointed. Approaches for including energy issues in planning processes are also suggested in terms of a MILP model for the entire supply chain of a pulp company, including decisions on purchase and transportation of raw materials, production allocation, energy mix, and distribution. Another example is presented based on the perspectives of economics of scale and lot sizing through economic order quantity principles in a steel company. By using real company data, energy smart approaches in planning and scheduling are developed with respect to the most important intersections between the production processes and their supporting energy system. The accumulated resource intensity and embedded energy could, and probably should, hence be more fairly reflected in the product price. The research finally shows some possible impact with including energy issues in a production and supply chain planning model. By planning differently, production prioritisations can be done, and it is not only possible without any large investments, but also prosperous with savings on both energy and money within reach.

To conclude, planning of production and supply chain has either a direct or an indirect impact on the energy cost-effectiveness of a company. This dissertation argues that such impact also exists in its mutual form, and is very important when the energy issues are large enough, as they often are in the energy intensive process industry sector. Decision makers should thus beware of the short end of the stick that might be devastating in the long run, but also aware of all the possibilities that can bring success and prosperity when the future begins. 


\section{Keywords}

Process industry, Energy-intensive production processes, Energy system, Energy management, Production planning, Supply chain planning, Case studies, Mixed Integer Linear Programming, Modelling, Specialty chemicals, Pulp, Steel 


\section{Sammanfattning}

Denna avhandling belyser industriella energifrågor ur ett produktionsekonomiskt perspektiv, med målet att göra skillnad inom den energiintensiva processindustrin. Energifrågan blir allt viktigare sett ur flera vinklar, inte bara vad gäller pris utan även med tanke på klimatfrågan med politiska påtryckningar som följd för alla energianvändare. Eftersom några av de största energianvändarna i vårt samhälle tillhör processindustrin är detta ett viktigt segment att analysera. Processindustrin är också kapitalintensiv och hanterar både stor och dyr utrustning, vilket gör planeringen av dess aktivitet extra viktig för att uppnå högsta möjliga kapacitetsutnyttjande. På förekommen anledning strävar denna avhandling till att dels utröna några av de viktigaste energiledningsfrågorna kopplade till långsiktig lönsamhet. Därtill är ambitionen också att undersöka synergieffekterna av att inkludera energifrågor i planeringen av produktion och dess försörjningskedja, samt att analysera möjliga konsekvenser av ett sådant förfarande inom processindustrin.

Tre olika studier på tre olika fallföretag har genomförts, analyserats och presenterats i fem vetenskapliga artiklar. Metodiken utgörs av både kvalitativa fallstudier och kvantitativ matematisk modellering och optimering. Forskningsfrågorna analyseras från både ett produktionsperspektiv och ett energisystemperspektiv, såväl separat som i kombination. Energi i dess olika former ses som den största källan till arbetskraft för processindustrin, vilket gör den både arbetsintensiv och energiintensiv. Denna avhandling ger exempel på några av de viktigaste dimensionerna i detta sammanhang att ur ett planeringsperspektiv ta hänsyn till. Svensk processindustri står således inför arbetsintensiva energiutmaningar.

En av studierna, genomförd på ett kemiföretag, lokaliserar flertalet förutsättningar för att sätta energiledning på den strategiska agendan inom företaget. Således belyses vikten av ett energistrategiskt perspektiv, hur energi används, samt möjligheterna till alternativ avsättning från biprodukter och alternativ användning av dessa. Avhandlingen lägger också fram olika metoder för hur energi kan involveras i planerings- 
processerna. Till att börja med föreslås en linjärprogrammeringsmodell för produktionen inom ett massaföretag och hela dess försörjningskedja, med beslutsvariabler för inköp och transport av råvara, produktionsallokering, energimix, samt distribution. Ett annat exempel föreslås för en stålindustri och baseras på principer för skalfördelar samt partiformning genom ekonomisk cykeltid. Dessa modeller matas med verkliga data från företagen och genom att ta hänsyn till de viktigaste beröringspunkterna mellan produktionen och dess stödjande energisystem är målet att utveckla ett energismart förhållningssätt till planering och schemaläggning. Således kan och bör den ackumulerade resursintensiteten och energiintensiteten bli mera rättvist representerad i produktpriset. Avhandlingen visar slutligen på tydliga möjligheter med att involvera energifrågor $\mathrm{i}$ planeringen av processindustriers produktion och försörjningskedja. Genom att planera annorlunda kan olika prioriteringar i produktionen göras. Det visar sig inte bara möjligt utan stora investeringskrav, utan också fördelaktigt med både energibesparingar och kostnadsbesparingar inom räckhåll.

Avslutningsvis kan det konstateras att planering av produktion och försörjningskedja har både en direkt och indirekt påverkan på såväl den inre som den yttre energieffektiviteten i ett företag. Avhandlingen visar därtill att denna påverkan är ömsesidig och speciellt viktig när energifrågan blir stor nog, vilket den ofta är inom energiintensiva processindustrier. Det ligger alltså stort ansvar på beslutfattare $i$ sammanhanget, inte enkom för att undvika många av de fallgropar en turbulent marknad kan medföra, utan också för att fånga alla de möjligheter som finns för att lyckas och bli framgångsrik när väl tiden är inne. 


\section{Tackord}

En process är för mig en uppsättning aktiviteter som förändrar inflöden till utflöden på olika sätt. När jag påbörjade mina doktorandstudier var min världsbild kanske aningen annorlunda mot vad den är idag. Under resans gång har jag fått stöttning och vägledning av ett flertal personer som jag härmed vill visa min största tacksamhet till. Först och främst vill jag rikta ett stort tack till mina handledare: Helene Lidestam, Martin Rudberg och Magnus Karlsson för all den energi ni ägnat åt att hjälpa och vägleda mig i min utveckling, både som handledare och som medförfattare och kollegor. Jag vill också tacka alla ni företagskontakter ute i industrin som bidragit med allt ifrån data och information till lukrativa diskussioner och intressanta synvinklar på alla de problem som forskningen analyserat. I detta sammanhang vill jag också tacka alla kollegor på framförallt Produktionsekonomi och Energisystem samt många andra avdelningar på IEI för möjligheten att diskutera och analysera relevanta aspekter av de forskningsproblem jag ställts inför. Ett särskilt tack till Patrik Thollander och Joakim Wikner för all konstruktiv feedback på tidigare versioner av denna avhandling, samt alla ni andra som också bidragit med för mig värdeskapande insikt användbar till dess utformning. Med detta vill jag också tacka alla mina kollegor för allt roligt vi haft. Ett särskilt stort tack vill jag rikta till alla mina doktorandkollegor som upplevt likande situationer som mig, situationer som vi trots diverse frustrationer emellanåt också haft väldigt roligt åt i flertalet ironiska och festliga sammanhang.

Som en produkt av processen doktorandstudier, har jag förändrats i dimensionerna tid, rum och form. Det har nu gått lite mer än fem år sen jag påbörjade mina doktorandstudier, och tio år sedan jag påbörjade min akademiska bana på industriell ekonomi, där jag lärde känna flertalet vänner för livet. När alla ni kände er klara, hade jag bara kommit halvvägs. Denna bana har också ändrats i rumsliga dimensioner eftersom vår galax idag inte befinner sig på samma plats som den gjorde då. Den största förändringen har nog dock varit i termer av form, och då tänker jag givetvis främst på strukturen av alla elektroner och atomer i mina informationsbärande hjärnceller. För de som tänkte på form i 
andra kategorier måste jag poängtera att jag också haft möjligheten att åtnjuta sportsliga aktiviteter i flertalet sammanhang. Jag minns särskilt allt kul vi hade, Johan och Bettan, när vi gjorde en svensk klassiker 2010, tack för allt trevligt vansinne jag fått uppleva med er!

Även om klockan tickat långsamt emellanåt inser jag nu att denna tid bara flugit förbi. Detta har tyvärr också tärt på möjligheten att umgås med alla $\mathrm{Ni}$ som verkligen betyder något i livet för mig. Tack för att $\mathrm{Ni}$ stått ut med min frånvaro och alla löften jag inte kunnat hålla, när jag stundom varit sinnesförvirrad av de problem jag ibland grottat mig ner $\mathrm{i}$ allt för djupt. Trots långa perioder av tystnad för många av er, har vetskapen av att $\mathrm{Ni}$ alltid funnits där dock varit stärkande och givit mig drivkraft att kämpa vidare. Ni i grabbfikagänget, kära bröder, med respektive, har med alla goa stunder, röllördagar, resor och guidade turer runt de utsocknes vänselhölera, betytt särskilt mycket för mig. Min gudmor och mina kusiner har givit mig stöd, personlig vägledning, samt inte minst livsinsikt kring rötternas betydelse i livets träd. Kära far och mor, inga titlar i världen kan för mig upphäva vikten av att också vara en jordnära åkerman. Ni har givit mig livets träd, förmågan att växa i kunskapens träd, förtroendet att vårda våra egna träd, samt hopp genom möjligheten att plantera nya träd. Jin, min älskade och blivande fru, du finns i mitt hjärta och tillsammans med dig vill jag leva lyckligt i en skog av kärlekens träd.

Linköping, November 2014

Martin Waldemarsson 


\section{Preface}

To the best of our knowledge our planet Earth has hosted life for billions of years in the light of its closest star: our Sun. Thanks to the Sun's energetic light, chemical reactions such as the photosynthesis could take place here on Earth. Using carbon dioxide and water together with sunlight, a coal-based life emerged and started to flourish producing oxygen and vast amounts of biomass. This became later on a necessity for animals, fish, amphibians, reptiles, birds, mammals and primates such as our-selves. A complex ecosystem was formed, highly sensitive for disturbances in the flowing circulation of its substances, such as the carbon cycle. Still today, we are highly dependent on the products of the early life-forms and their production of biomass. Buried under the ground for millions of years, it turned into coal, oil and natural gas as we know it. These fossilised energy carriers are thus nothing else than accumulated products of sunlight, transformed through photosynthesised processes that took place hundreds of millions of years ago. Our utilization of this stored energy is however several million times faster than the rate in which it became transformed and stored trough biological and tectonic processes. Doing the math, and counting the years, it becomes obvious that this source of energy will not last forever at the current burn-rate.

The history of mankind is rather young in the big picture. During the vast majority of our history we lived as hunters and gatherers, spending most of our time to collect food. Not until after the agricultural (Neolithic) revolution took place, some twelve thousand years ago, our ancestors got enough spare-time for innovative thinking, leading to the development of new tools and technological innovations, and the idea to utilize other animals for workforce in agricultural processes became a reality. In fact, looking closer to the concept of work; a systems ability to perform work can be measured in its amount of energy. At this time of our history we became obsessed of external energy supply and were many times prepared to do anything to achieve it. When civilizations rose and became too large for what the close-by nature could carry, and when the "number of cows was not enough" as it is so vividly is expressed in Sanskrit, conflicts followed and civilizations fell. Nevertheless, in the advent of the industrial revolution, access to a seemingly unlimited but newly discovered workforce bounded in fossil fuels became imperative for our rapid technological and societal development. Consequently, well-fare and prosperity followed for those who developed successfully, and the dream of following this pathway was spread across the globe.

Industries developed to become more productive and more efficient but also atomized to produce products almost without the input of a human workforce. The yearly global use of energy today amounts to about $140 \mathrm{PWh}$, that is 140 billion megawatt hours (MWh), and most of it has fossil origin. This amount of yearly energy use is somewhat equivalent to accelerating 1.6 million $\mathrm{km}^{3}$ of water to the speed of $90 \mathrm{~km} / \mathrm{h}(25 \mathrm{~m} / \mathrm{s})$, every year. Such amount of water is enough to cover the whole planet with more than 3 meters. To compare, let's assume that a normal human body can sustain a power of 125 watts at normal work load. A normal eight hour working day is then about one kilowatt hour (kWh) worth of 
energy, and could be bought for less than a tenth of a US dollar on the fossil fuels market. Calculating with 235 working days per year, discounting for vacation and holidays, our yearly global energy use is then equivalent to about 600 billion man-years, a workforce enough to through the old fashion way build about one million pyramids similar to The Great Pyramid of Giza per year. Obviously, or at least hopefully, we have found better use of this energy than to accelerate water or to build vast amounts of pyramids for no reason, but one might still wonder if the price of energy really reflects the potential of its content.

However, despite all the technological development that simplifies the lives of billions of people today, we have reached a society far from perfect from a global point of view. Several so called sustainability errors occur in the world we live in and the problems with for example climate changes seem to grow faster than our capability to solve them. An increase of almost fifty percent on the atmospheric carbon content, relative to the pre-industrial era, is highly alarming considering the sensitivity of our ecosystem for climate change. The best available solutions are up for debate and trial, and powerful stakeholders defend their own will and suggestions. Nevertheless, there are plenty of alternatives for how our energy system could develop, some more beneficial than others. On the energy use side, energy efficiency developments in all sectors, especially the energy intensive industry sector involving many process industries, seem very promising and cost efficient. By developing managerial implications on how to do things better and how to prevent unnecessary work to be done, we might not need as much energy as we think we need. On the energy supply side there are for instance renewable energy sources such as solar- and wind power technologies rising, alongside with a more industrialized way to utilize our biomass. The economic competition is tough and economics of scale are often missing in order to be competitive with the fossil fuels. However, the technological potential of renewable energy sources is expected to be much larger and way more than enough to cover our daily needs as of today.

It has been said that we, the homo sapiens sapiens, are the only species on our planet aware of its own existence. But one might wonder if our awareness of other species and their necessities for life is sufficient enough. Getting some perspective, it is possible that some atoms in your right hand might originate from different stardust than some of the atoms in your left hand. Yet, maybe the fate of perhaps more than our own species is in the hands of our decisions today. It is here the complexity of sustainable development becomes a reality for us. The buzzword "sustainable" itself is very tricky in the many contexts it appears, and today it seems to appear everywhere, used more and more and sometimes without actually knowing its meaning. For me, there are utmost two expressions that I feel are closely connected with this buzzword. One is related to "what nature can carry", and relates to the ecosystem and the flowing circulation of its substances that needs to be in balance. The other is the Swedish word "lagom" which is rather difficult to translate. According to the mythology of the origin of this expression, it goes way back in history to the Iron Age or Viking Age. At that time, when people gathered for eating and drinking, the mythology says that they did so from the same bowl in the middle of the table. To be social and show 
respect for each other's, you should simply take "not too little, not too much, but just the right amount" so it is perfectly enough for everyone. No matter if the story of the origin of the word is correct or not, the story explains very well the meaning of the word. However, symbolic resemblances and subjective feelings with the buzzword "sustainable" could nevertheless make the word itself very politically charged in many occasions. That is probably why actions in the goodwill direction of sustainability often become very fuzzy and unspecified, and one of the reasons why many choose to avoid using the word. Nevertheless, according to common sense everybody wants a better future, and few people really say directly no to ecologically friendly development. How this should be achieved and paid for turns, on the other hand, out to be problematic to agree upon. Our civilization is large but fragile in this matter, and seemingly, we turned from hunters and gatherers to consumers never satisfied. The economy we practice today, that however might be the engine for the development of our society, take place in a world where money talks and consumption is believed to result in growth. In this sense one should however reflect on the meaning of economics as "household management" of finite resources. Production and not consumption, should as the creation of value instead be seen as the true contributor to growth in this context. Hence, managing production in an economic way with respect to finite resources is then the key for future growth. Nevertheless, the task to improve our society still remains tremendously large, but we believe feasible solutions exist, and maybe they are inevitable if the lack of cows of our time is to be prevented. Given the rules of the game, it therefore seems like reaching for cost savings and optimizing the economic systems we practice, is where the battlefield of future development will take place. 



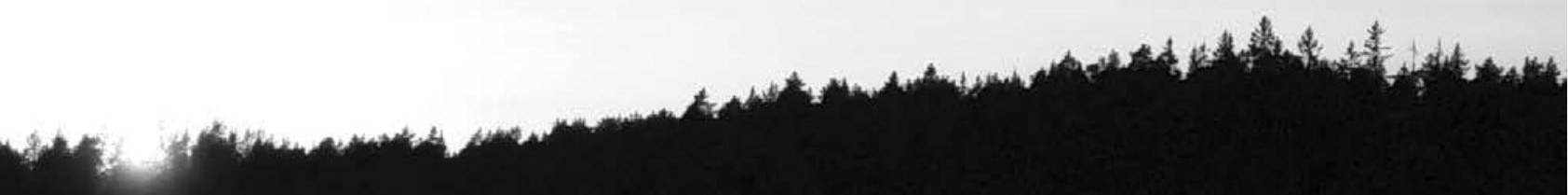

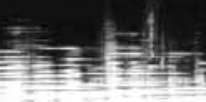


May our heritage not be used in vain. 


\section{Outline}

This publication entitled Planning production and supply chain in energy intensive process industries is a doctoral dissertation in the field of Production Economics at Linköping University. The dissertation consists of two parts; first an introductory and summary part, and second a collection of five papers. The first part introduces the topic, overall purpose and research questions, and summarizes the papers. Moreover it analyses the essence of the research being done and its contribution in relation to the current state-of-the-art found in the literature. Some ideas for further research are also proposed. The second part comprises the papers listed below, where the origin and the current state of publication is noted.

\section{Paper 1}

Rudberg, M., Waldemarsson, M. and Lidestam, H. (2013) "Strategic Perspectives on Energy Management: A Case Study in the Process Industry", Applied Energy, Vol. 104, pp. 487-496.

An earlier version of this paper was presented at EurOMA 2010:

Waldemarsson, M., Rudberg, M. and Lidestam, H. (2010) "Energy management in process industries: current practices and future challenges", Proceedings of the EurOMA 2010 Conference, held $6^{\text {th }}-9^{\text {th }}$ June 2010 in Porto, Portugal.

\section{Paper 2}

Waldemarsson, M., Lidestam, H. and Rudberg, M. (2013a) "Including energy in supply chain planning at a pulp company", Applied Energy, Vol. 112, pp. 1056-1065.

An earlier version of this paper was presented at ICAE 2012:

Waldemarsson, M., Lidestam, H. and Rudberg, M. (2012) "Including energy in supply chain planning at a pulp company", Proceedings of the Fourth International Conference on Applied Energy (ICAE2012), held $5^{\text {th }}-8^{\text {th }}$ July 2012 in Suzhou, China. 


\section{Paper 3}

Waldemarsson, M., Lidestam, H. and Karlsson, M. (2014a) "How energy price changes can affect supply chain planning at a pulp company", in review.

An earlier version of this paper was presented at ICPR 2013:

Waldemarsson, M., Lidestam, H. and Karlsson, M. (2013b) "How energy affects supply chain planning at a pulp company", Proceedings of the $22^{\text {nd }}$ International Conference on Production Research (ICPR22), held $28^{\text {th }}$ July $-1^{\text {st }}$ August 2013 in Iguassu Falls, Brazil.

\section{Paper 4}

Waldemarsson, M., Lidestam, H. and Karlsson, M. (2014b) "Energy issues in supply chain and production planning in the steel industry - A case study at SSAB", Working Paper.

An earlier version of this paper was presented at IWSPE18 2014:

Waldemarsson, M., Lidestam, H. and Karlsson, M. (2014c) "Energy issues in supply chain and production planning in the steel industry - A case study at SSAB", in Grubbström, R.W, Hinterhuber, H.H., (Eds), PrePrints, Vol. 1, $18^{\text {th }}$ International Working Seminar on Production Economics, Innsbruck, Austria, $24^{\text {th }}-28^{\text {th }}$ February, 2014, pp. 489-501.

\section{Paper 5}

Waldemarsson, M. (2014) "Energy considerations in planning slab furnaces at a steel company - A case study at SSAB", Working Paper. 


\section{Contents}

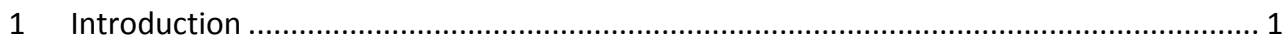

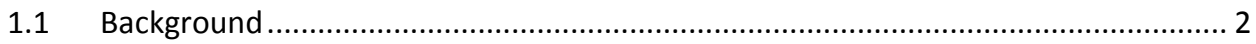

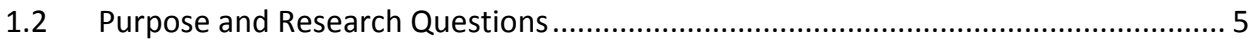

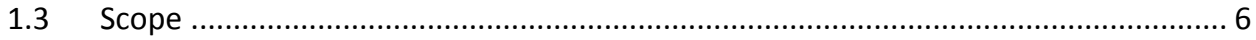

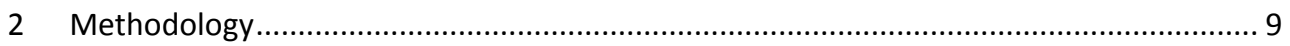

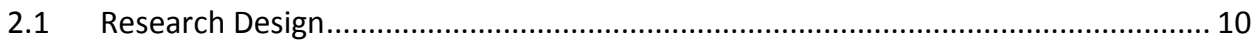

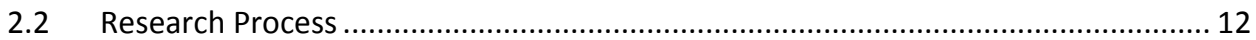

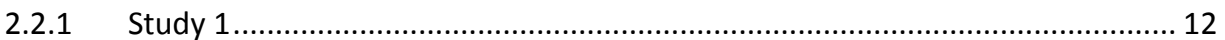

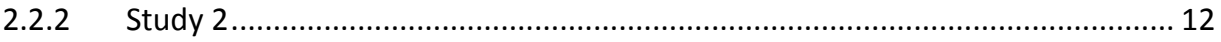

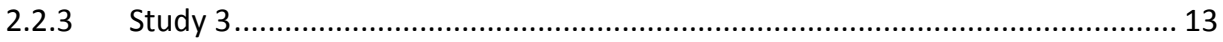

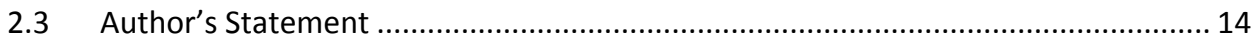

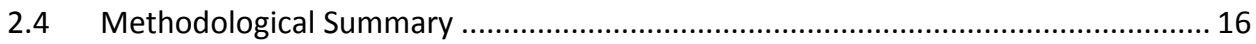

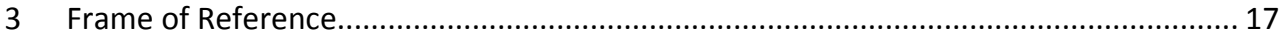

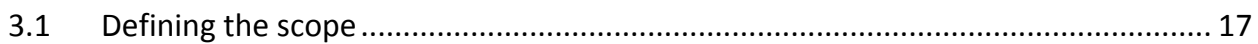

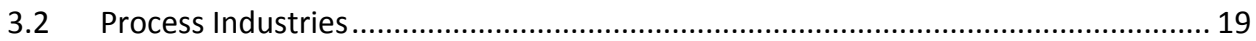

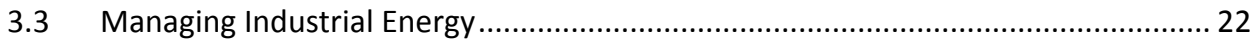

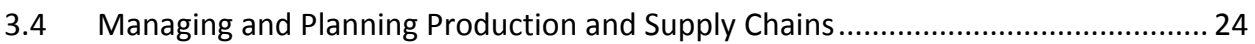

3.4.1 The strategic, tactical, and operational point of views .................................... 25

3.4.2 Capacity Utilization and Investments............................................................. 26

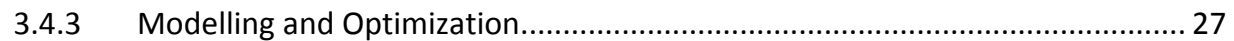

3.5 Including Energy when Planning Production and Supply Chain .............................. 31

3.5.1 Complex Planning Issues around Energy .......................................................... 32

3.5.2 Mathematical Modelling in Process Industries .................................................... 33

3.5.3 Integrating Energy Issues in the Planning Processes ...................................... 33

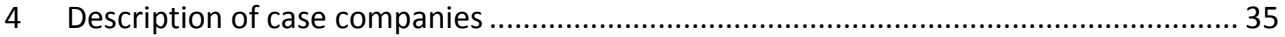

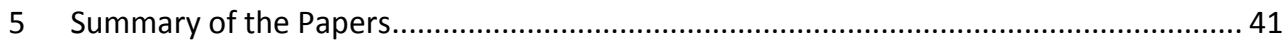

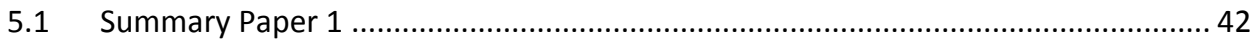

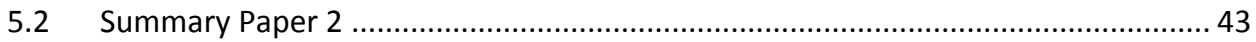

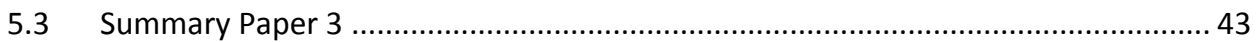

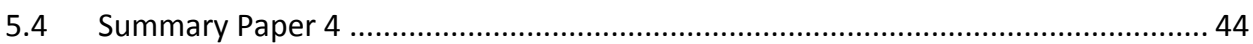

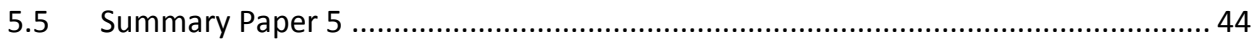




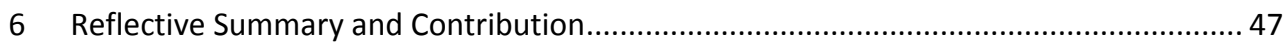

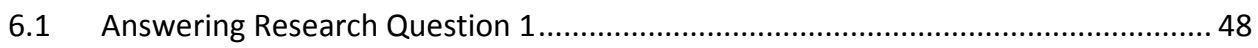

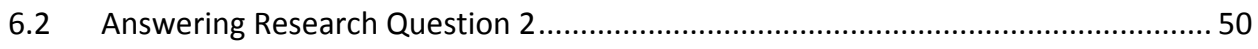

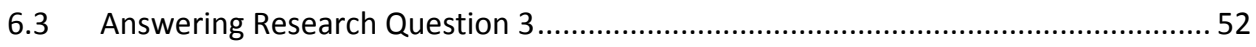

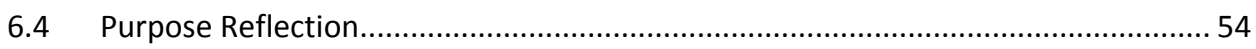

7 Concluding Discussion and future research ideas .................................................... 57

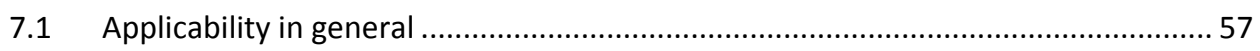

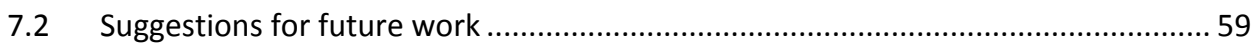

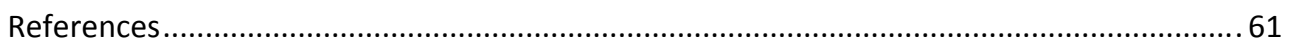

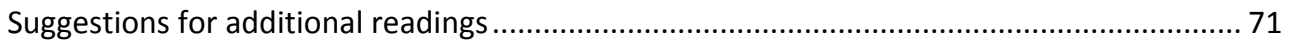

Papers

Paper 1. Strategic Perspectives on Energy Management: A Case Study in the Process Industry

Paper 2. Including energy in supply chain planning at a pulp company

Paper 3. How energy price changes can affect supply chain planning at a pulp company

Paper 4. Energy issues in supply chain and production planning in the steel industry - A case study at SSAB

Paper 5. Energy considerations in planning slab furnaces at a steel company - A case study at SSAB 



\section{Introduction}

When I grew up we heated our house with wood as fuel for our central heating system. The use of wood as fuel was economically beneficial for us, since the waste trees available from our forests, was comparably unprofitable to sell. Despite the vast availability, at least from my point of view at that time, my father always said that the best wood would be saved for the coldest part of winter. By that he of course meant the hardwood, such as birch and oak, that has high energy content. The softwood, containing a lower heating value, could instead be used all the year around to fill the daily needs. My research today try to adopt a similar philosophy, but in a larger scale.

For most companies in the big world out there, long term profitability and providing value for the owners, is often considered to be the very foundation of its existence and survival. This can be achieved in many different ways, some more successful than others, but commonly most industries need input of capital, resources, and workforce often in terms of energy. A wisely chosen mix of these ingredients can then pave the way for prosperity and success. The ingredients can also be handled, controlled, managed, and processed in many different ways within the company and among its different functions; such as for instance by financial measurements, by planning procedures, trough production and manufacturing, along supply chain processes, and by utilizing an energy system. These activities and processes, and several others, interact with each other in many different ways, on different levels, with different amounts of management and control involved, trough different operations, and for different purposes, but all with the same goal: supporting the business of the company. How to manage these activities and how to interact them together in order to maximize the profit for the company is therefore a relevant question to ask and analyse. In process industries these interactions are probably not more occurring than in other types of industries, but the intersections between some of the activities and processes in particular are more important and have larger impact on the company than others. In this dissertation, I will focus on the production planning and supply chain planning in energy intensive process industries. 


\subsection{Background}

Almost everything you use at home, buy in the store, or even eat, has been processed through a process industry in one way or another. No matter if it is a fluid, a powder, or solid, made of wood, plastics, metal, or fibre, the item and/or its material has been processed through either melting, pumping, boiling, mixing, separating, forming, and/or by chemical reactions. These characteristics are typical for process industries that normally can be found very early in the value chain, as either basic producers producing materials from natural resources to be used by other manufacturers, or as a converter producing a variety of industrial and/or consumer products (Finch and Cox, 1987). As such, very few things in our daily life have its origin outside the touch of a process industry. Productivity and efficiency improvements are thus always welcome in process industries, and concepts like availability, controllability and flexibility (IVA, 2006) are becoming more important in the footsteps of market globalization and product competitiveness.

Process industries are in general very capital intensive, involving a lot of resources, and most of them are also very energy intensive (Thollander and Ottosson, 2010; Taylor et al. 1981a). With such production processes, the managerial task is very much focused on utilising the production equipment as much as possible (Taylor et al., 1981a), which is why process industries often run day and night, all year around. The capital intensiveness, partly due to the large investments needed in production equipment, makes planning and control imperative for the utilization of this equipment. Production planning therefore tends to be capacity orientated (Taylor et al., 1981a) and is considered very important, as a key module deciding operating activity and resource utilisation, in many process industries (Taylor et al., 1981b). Many process industries are also rather unique in their production characteristics and layout, and a tailor made planning approach is thus often preferred (Ashayeri et al., 2006).

At large, the energy sector is essential for our society and represents a very large proportion of the economy. Of the twenty largest companies in the world, listed at Fortune (2014) index GLOBAL 5002014 in terms of annual revenue, nine companies represent the energy sector trough oil and gas, and additional two act on the power supply and energy distribution market. Together, these eleven companies represent 3.4 trillion US dollar (62\%) of the revenues among the twenty largest companies in the world (Fortune, 2014). But whereas the energy sectors financial impact is large, its environmental impact might become even larger. However, in the dawn of the anthropogenic climate change mainly caused by the use of fossil fuels (Plass, 1956; IPCC, 2014), the political pressure is growing and a renewable energy revolution is potentially around the corner. One could thus expect huge changes for utmost the energy intensive industries in a not too distant future. On a global scale, the industrial sector stands for almost two fifths of the total end use of energy, and typical process industry environments represent more than half of the use of energy within the industrial sector (share of industrial energy use); chemicals (including feedstock, 19.3\%), iron and steel $(15.0 \%)$, non-metallic minerals $(6.8 \%)$, pulp and paper $(3.4 \%)$, and refining $(6.8 \%)$ 
(EIA, 2013). Process industries are thus very energy intensive and stand for almost one fifth of the global use of energy (EIA, 2013; Özdamar and Birbil, 1999). In Sweden, industry stands for $38.5 \%$ of energy end use (Swedish Energy Agency, 2014), which is in line with the global average, but in Sweden the process industry represents a very much larger share of industrial energy use than compared to its global average. In Figure 1, about $80 \%$ of all industrial energy use in Sweden is positioned in 22 major energy lines (indexed from a to v), and almost all of this use of energy is very much connected with typical process industry activity. It is almost only the categories for the bubbles indexed with q and s (representing $2.4 \%$ of all industrial energy use) that could be said to not be highly involved with process industry activities in this matter.

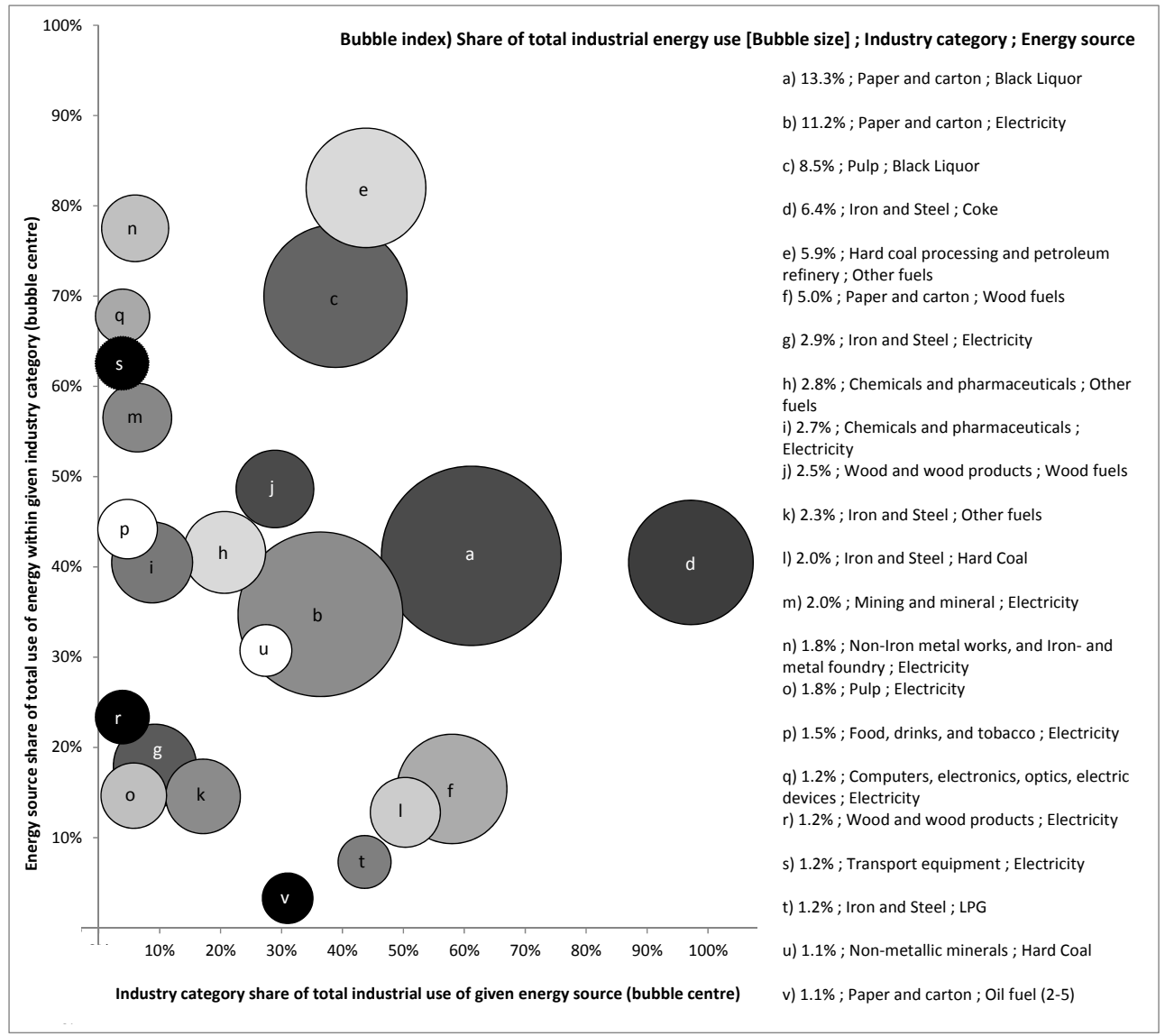

Figure 1 - With an individual bubble for each type of energy used in each industry category, a total of $80 \%$ of all industrial energy use in Sweden during 2011 is positioned and divided into the 22 major energy lines indexed from a to $v$ (Underlying data source: SCB, 2014a).

To exemplify the content of Figure 1 (looking at category c: pulp); about 39\% of all black liquor used within Swedish industry is used in the pulp industries, and black liquor stands for $70 \%$ of all energy use in pulp industries. The energy source black liquor used in the pulp 
industries furthermore represents $8.5 \%$ of all industrial energy use in Sweden. This together with the use of electricity in pulp industries (category o) represents in Figure 1 about $85 \%$ of all energy use in pulp industries. In comparison to the pulp industry, electricity stands for $63 \%$ of all energy used for producing transport equipment (category s), but reaches only $3.8 \%$ of all electricity used within Swedish industry. In Sweden, the transport equipment industry, mostly represented by e.g. the Volvo Group, Volkswagen AG (through Scania), Volvo Car Group, and National Electric Vehicle Sweden AB (Nevs) (former Saab Automobile), is considered large and important in many other ways for the Swedish economy, but in this case they only represent $1.9 \%$ of all Swedish industrial energy use. As a matter of fact, of all industrial energy use in Sweden, the pulp and paper industry stands for about $45 \%$, the iron and steel industry stands for about $16 \%$, and the chemical and pharmaceutical industry stand for about 7\% (SCB, 2014a). In this dissertation, companies belonging to each and one of these three energy-large categories just mentioned are investigated. As such, the industry segments responsible for about two thirds of all industrial energy use in Sweden, that is slightly above one quarter of all Swedish energy use, are somewhat represented in this dissertation.

The vast amount of energy used in process industries is also associated with large costs. The energy costs are often more than $15 \%$ and sometimes reaching half of the operative cost in many process industries (Thollander et al., 2009). The interactions between the corresponding production processes and energy systems involved have therefore large impact on the company as such. However, the energy system in the company is commonly viewed upon as a support function and not always included in the planning process of the production and the supply chain. It is therefore mostly considered from the cost-perspective, which might not always be beneficial, presumably not when an energy surplus can be extracted from the energy system and provide additional revenue possibilities. Nevertheless, by economic value of all Swedish export of goods during the year 2013, the pulp and paper industry stood for about $8.3 \%$, the iron and steel industry for about $4.3 \%$, and the chemical industry for about $4.1 \%$ (SCB, 2014b). The process industry altogether accounts for about $30 \%$ of the total exports from Sweden, and about $60 \%$ of the total net export, due to a large proportion of domestic raw materials (IVA, 2006). As such, research on process industries may not only have a large impact in terms of the Swedish use of energy and its costs, but also in terms of economic value for the nations export.

Since our dependency of process industries is large, since they involve a lot of resources, are capital intensive, and thus make planning imperative for their utilization, and since energy costs stands for about $15 \%$ to sometimes half of their operative cost, and since they all together stand for almost one fifth of the global use of energy, and since they are thus an enormous sector with huge environmental impact in our society, I have reasons enough to motivate at least myself for researching on energy intensive process industries. Therefore, the questions how process industries use energy for production and how this relates to the planning procedures of their activities and processes, pinpoints an interesting field to 
investigate. This field of research is however not new in the literature and some research has been done within this area. Nevertheless, the idea in this dissertation is that process industries can save both costs for production and costs for energy usage simultaneously by planning its activities and processes differently. Some industries might even increase their revenue possibilities by rescheduling their activities and processes, making energy issues very essential from a planning perspective. To as such deliberately pay extra attention on energy management aspects within planning of process industry production and its supply chains is however not that well represented in the literature, and thus an area worthy to further investigate.

\subsection{Purpose and Research Questions}

The core of this dissertation can be narrowed down to include energy management aspects in production and supply chain planning among energy intensive process industries. Considering the background and located area of interest, the purpose of this dissertation is therefore to

identify important energy management aspects related to production planning and supply chain planning in process industries, and investigate if a coordinated planning approach, considering these areas, is possible and could be profitable.

In order to fulfil this purpose, a large focus is put on analysing the opportunities provided when energy is included in production planning and supply chain planning on strategic and tactical levels. The purpose is more specifically formulated in three research questions to be presented.

The first question relates to identifying important energy management aspects and to investigate how process industries view their energy issues in general. As such, the following research question arises:

$R Q 1$. How do current energy management practices in process industries relate to the task of ensuring profitability both today as well as beyond tomorrow?

With the second question I strive to investigate the symbiotic effects of merging energy issues with planning issues of the production and the supply chain:

$R Q$ 2. How can process industries include energy related issues in their planning processes of production and supply chain? 
Whereas the first two research questions aim at mapping and analysing energy issues (RQ 1 ) and its possible integration in planning procedures (RQ 2), the third focuses more on the possible consequences of practicing a wider perspective on these issues. As such, in order to investigate the potential impact in terms of both energy use and corporate profitability of such practice, the third question reads as follows:

$R Q$ 3. How can the merging of energy issues into the planning processes for production and supply chain impact the profitability of the process industry?

To fulfil the purpose, the dissertation furthermore intends to contribute in terms of suggesting models and methods as decision support for handling the area of interest considered. Another intention is to also increase the awareness of how energy issues and planning issues can be integrated and coordinated in energy intensive production environments.

\subsection{Scope}

This dissertation addresses process industry related problems within the fields of Energy Management (EM) and Operations Management (OM), which intersection to some extent sets the dissertation's theoretical foundation. These fields are more specifically defined in Chapter 3.1. The scope of the dissertation is thus concentrated to, but not limited to, the intersection of these fields, as illustrated in Figure 2.

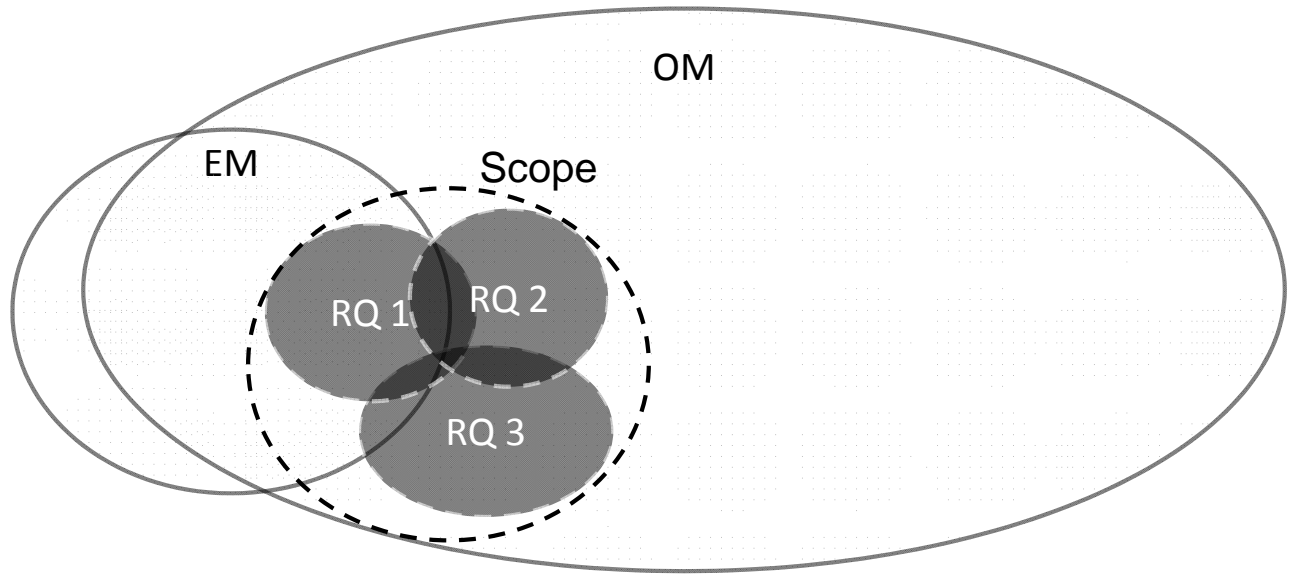

Figure 2 - Scope of the dissertation and the Research Questions (RQs) from a theoretical field point of view, and as a part of Operations Management (OM) and Energy Management (EM). Not necessarily according to scale.

The third large area of this dissertation is concentrated to planning in process industries. This research can involve several different levels of the company focusing on the entire enterprise, a production site, a certain production area, a production unit, or specific 
equipment and their instrumentation. Theoretical approaches can moreover be taken from the perspectives of production planning and supply chain planning, an optimization perspective, and/or an automatic control perspective. The scope of the dissertation with respect to these dimensions is illustrated in Figure 3.

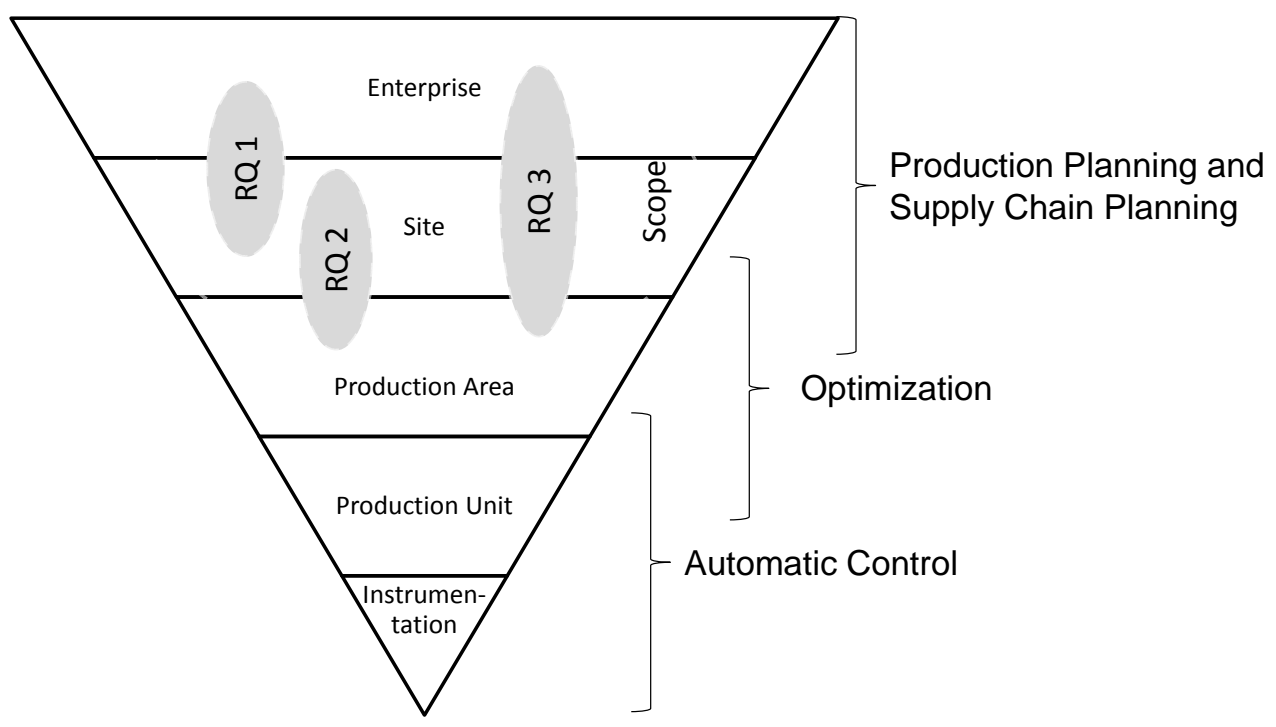

Figure 3 - Scope of the dissertation from a process industry perspective, with inspiration from Process Industry Centre (PIC, 2014).

The remaining part of this dissertation begins with a methodology chapter describing the research design and process. This is followed by Chapter 3 where a frame of reference is discussing the theoretical concepts and the literature related to this research. The empirical data for the research has its origin in three different case companies, and an overview of this empirical environment is presented in Chapter 4. Five individual papers have been written that to some extent is based on case studies on the case companies involved, but also based on mathematical modelling and analysis of developed models. The papers are presented and summarized in Chapter 5 and is followed by the results of the dissertation and some concluding remarks in Chapter 6. Finally a general approach and some further research ideas are discussed in Chapter 7. The five research papers are attached at the end. 


\section{Methodology}

In this chapter the research methodology is presented in terms of research design and research process from both a summarizing point of view as well as more in detail for each paper. The chapter also discusses the methods used from a validity and reliability perspective regarding the results achieved.

The research is in general based on the three research questions previously presented in the introduction. Three major studies have been performed one after the other, each providing input for all research questions to various degrees. The first study is presented in the first paper. The second study is presented in Paper 2 and Paper 3, whereas the third and final study is presented in Paper 4 and Paper 5 . This structure is illustrated in Figure 4.

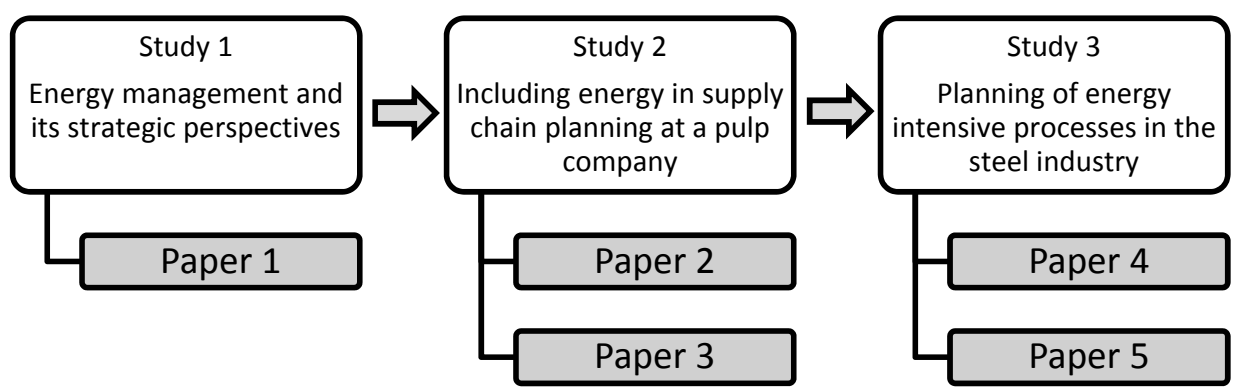

Figure 4-Research process overview.

The first paper is based on a case study at Perstorp which is a specialty chemicals company. The second study is partly a case study but has moreover a mathematical modelling approach to a supply chain problem at Södra Cell. A model is introduced in Paper 2 and more deeply analysed in Paper 3 . The third study is basically a case study and generally described in Paper 4, and more specifically analysed in Paper 5 with scenario-based calculations. 


\subsection{Research Design}

The first study and its corresponding paper reflect the topic of the first research question. The second question is mainly reflected in the second and third studies and more specifically in Paper 2, and also in Paper 4 and Paper 5. The third research question is mainly reflected in the second and third studies, and more heavily analysed in Paper 3 and Paper 5. A brief description of the relation between each research question and each study and paper is presented in Table 1, aiming to describe the coverage of each paper and study on each questions topic.

Table 1 - Research question and topic coverage by each study and paper.

\begin{tabular}{|c|c|c|c|c|c|c|}
\hline \multirow{2}{*}{\multicolumn{2}{|c|}{$\begin{array}{l}\text { Coverage: } \\
* * * \text { Major }\end{array}$}} & \multirow{4}{*}{$\begin{array}{l}\text { Study } 1 \\
\text { Paper } 1\end{array}$} & \multicolumn{2}{|c|}{ Study 2} & \multicolumn{2}{|c|}{ Study 3} \\
\hline & & & \multirow{3}{*}{ Paper 2} & \multirow{3}{*}{ Paper 3} & \multirow{3}{*}{ Paper 4} & \multirow{3}{*}{ Paper 5} \\
\hline$* * \mathbf{M}$ & derate & & & & & \\
\hline \multicolumn{2}{|c|}{ *Minor } & & & & & \\
\hline RQ1 & $\begin{array}{l}\text { How do current energy } \\
\text { management practices in process } \\
\text { industries relate to the task of } \\
\text { ensuring profitability both today } \\
\text { as well as beyond tomorrow? }\end{array}$ & $* * *$ & $(*)$ & $(*)$ & $* *$ & $*$ \\
\hline RQ2 & $\begin{array}{l}\text { How can process industries } \\
\text { include energy related issues in } \\
\text { their planning processes of } \\
\text { production and supply chain? }\end{array}$ & $(*)$ & $* * *$ & $*$ & $* *$ & $* *$ \\
\hline RQ3 & $\begin{array}{l}\text { How can the merging of energy } \\
\text { issues into the planning processes } \\
\text { for production and supply chain } \\
\text { impact the profitability of the } \\
\text { process industry? }\end{array}$ & $(*)$ & $* *$ & $* * *$ & $*$ & $* * *$ \\
\hline
\end{tabular}

The design chosen for conducting the case studies has been based on Yin (2009). Case studies are considered to be one of the most powerful research methods (Voss et al., 2002) and are very common in the field of operations management. Working with case studies one can follow a certain procedure suggested by Yin (2009): Plan, Design, Prepare, Collect, Analyse, and Share. These steps are in general followed throughout the first study as well as throughout the case study related processes in the other two studies. As such, all papers are to various degrees built up by case based research. Some iteration with going back and forth between the steps in Yin's (2009) case procedure, to refine the studies, have also occurred and considered somewhat healthy to the quality of the studies. Case studies are especially suitable when typical questions like how and why are asked (Yin, 2009). Since this is the case for the research questions of this dissertation it thus motivates the chosen design for the related studies. With this case study approach, a picture of the scope is quickly made, making it easier to set up limitations and system boundaries of the research project. According to Yin (2009), a case study can moreover be defined as an empirical investigation 
that analyses a present phenomenon in its real context, especially when the boundaries of the problem are diffuse. Complex technical situations, where often more variables than data are of interest, can also be handled effectively by case studies. However, case studies rely to various degrees on multiple sources of information, used to triangulate data, in order to validate results. It could also be easy to be overwhelmed by all the data unless focus is on the core of the research (Eisenhardt, 1989). Nevertheless, with a logical design, use of proper techniques for data collection, and with a specific approach for analysing data, as Yin (2009) suggests, case studies can be very effective. These aspects have been considered in the planning stage of the case based research in this dissertation.

When designing case studies one should aim for a logical connection between the initial case study questions, data gathering, analysis, and expected conclusions (Yin, 2009). Therefore, a study focus has been defined in order to set the direction for each case study, whereas literature studies have resulted in theoretical frameworks setting the scope of the research. The design is identified to in general be holistic for the case studies performed. By using multiple sources, chains of evidence, and verifications by key informants, research has aimed at constructing validity. Pattern matching and explanation building are used for internal validity, whereas external validity is achieved by using theory, and by repeating the logical structure. The use of a case study protocol and the development of a case study database, strengthen the reliability of the case studies, also in line with Yin (2009).

In order to ensure the quality of the research there have been sufficient Preparations before data collection, where the case study protocol and its plan has laid the fundamental agenda in the data gathering process. The step: analyse, consists partly of the composing part of each paper, but it is also done through calculations and structuring results in the parts where scenarios and models have been used for analytical purposes. The last part, share, is done for both the companies involved and the research community in general by presenting reports and papers for the company personnel as well as at scientific conferences, and through publications in scientific journals.

Whereas paper 1 and paper 4 are qualitative in their methodological design, paper 2, and paper 3, can in general be seen from a quantitative modelling approach (e.g. Bertrand and Fransoo, 2002) and paper 5 as a mixture of both. A quantitative approach has a set of variables that varies over a specific domain, and that are connected with casual relationships in-between. Mitroff et al. (1974) present a framework for quantitative research, in which there are four different dimensions that can be included and six different processes. The four dimensions: the problem situation in reality (I), the conceptual model (II), the scientific model (III) and the solution (IV), function as corner stones in the model by Mitroff et al. (1974). The processes in-between the four dimensions are 1) Conceptualization between I-II, 2) Modelling between II-III, 3) Model Solving between III-IV, 4) Implementation between I-IV, 5) Feedback between II-IV, and 6) Validation between I-III (Mitroff et al., 1974). Paper 2, and paper 3, involving conceptualization, modelling, and model solving, is empirical and 
normative (Bertrand and Fransoo, 2002) in its approach, although the implementation phase is yet left ahead. Paper 5 is in comparison more in a conceptualization and modelling stage.

\subsection{Research Process}

During the entire research process briefly described in Figure 4, literature studies have taken place more or less continuously. General information about the case companies involved has also been collected from public material, especially in the beginning of each study. Very much of the data collection has moreover been made through interviews. The interviews have most of the time been semi structured and somewhat flexible in order to fit each situation and to also allow spontaneous but applicable questions to take place. In general however, a premade questionnaire has been used and notes have been taken at all meetings and interviews that were known in advance and thus could be prepared for. If more than one researcher has been present at the interview, one has been the main responsible for asking and following up questions whereas the other has been responsible for taking notes. Due to the sources of the information, the researchers have also been aware of the various problematic issues that can occur with biased information. To avoid parts of such problems the interviewees are kept anonymous. Nevertheless, the process for each study and resulting papers is also presented more in detail in this chapter.

\subsubsection{Study 1}

The first paper is besides a literature review also based on a case study that, in line with Yin (2009), has an explorative nature. The case company Perstorp is a specialty chemical process industry and the study focus has been the use of energy management and its strategic importance at the company. Data has been gathered through semi structured interviews among personnel working with operational, tactical, and strategic management issues. An extra focus has also been made regarding those working closer to energy management issues in this context. As such, multiple sources of data have been used and valid results can therefore be achieved from triangulation. A case study protocol has been composed and used as a guiding tool in the data gathering process, as well as for the data verification process when contacting the company personnel. To further ensure the reliability of the case study as Yin (2009) suggests, the case study database, as well as the case study protocol, was of good help.

\subsubsection{Study 2}

The second study is partly based on a single case study, in line with Yin (2009), at the pulp company Södra Cell, and can be divided into two parts. In the first part, the study focus has been the structure of the supply chain, the production processes, and the energy system. As such, a real problem situation for the case company has been conceptualized and modelled into a scientific mathematical model, in line with Mitroff et al. (1974). This model is partly based on a previous model developed by Gunnarsson et al. (2007) and modified by Gunnarsson and Rönnqvist (2008). In this dissertation the previous model is referred to as the Mill Mission model, which in a modified form is currently in use at the case company for 
supply chain planning purposes. This study builds a new model, referred to as the Energy Mission model, partly based on the Mill Mission model, but simplified in several ways and more importantly; rebuilt to also include energy issues in the supply chain planning context. As such, a mixed integer linear programming (MILP) model has been built, and expanded to involve energy issues. The supply chain data origins from real company data used in the Mill Mission model at the company, and additional data for energy is gathered from process engineers and managers through a case study based approach at the company sites. The Energy Mission model is first presented in Paper 2, which thus represents the results of the first part of this study. The first part also provided insights in how to include energy parameters and variables in a supply chain model and how to intersect with corresponding parameters and variables for production and product characteristics. The second part refines the Energy Mission model, and simulates the use of it through analysing the results of several scenarios. The study focus in the second part is therefore considered to be the planning model for the supply chain, the production processes, and the energy system. As such, the expected results of an implementation of the Energy Mission model is presented, analysed, and discussed. The analysis and simulation results are presented in Paper 3, representing the results of the second part of this study.

\subsubsection{Study 3}

The third study is based on a case study at the steel company SSAB, and has a descriptive, but also somewhat exploratory, nature. This study is also made in two parts where the study focus in the first part is the production processes and energy system interactions at one of the case company sites. The case study follows the single case guidelines provided by Yin (2009). In the data gathering process, meetings and semi structured interviews among personnel, together with external reports, internal documents, and production process data and energy system data, have provided sufficient informative material for the case analysis. The semi structured approach increases the reliability and the data has also been verified with the company personnel and thus validated. The second part of the study is partly built upon the first part, but is more focused at one of the areas briefly investigated in the first part. As such, the study focus in the second part of the study is the planning of a production process with high energy impact. In terms of methodology, the case study approach follows the same structure and procedure as the first part of this study, with a descriptive data collection process and a more exploratory analysis phase. The problem described is conceptualized into a one period and non-linear model of the related production and energy flows, which is moreover used for calculations of different strategies in different scenarios. An economic cycle time approach has been used to determine the cost for inventory and setups. The model use real company data as input for the calculations, verified with the company personnel and thus validated. Reliability is moreover increased by the semi structured approach on interviews. The result from the second part of the study is presented in Paper 5. 


\subsection{Author's Statement}

The research in this dissertation is performed within the Process Industry Centre (PIC), supported by the Swedish Foundation for Strategic Research (SSF). PIC is divided into PIC-Li at Linköping University and PIC-Lu at Lund University, each collaborating with several process industries. The author of this dissertation has been a PhD student within PIC-Li and has done research studies at most of the member companies. The content in this dissertation is however mainly based on studies at three of them; Södra Cell, Perstorp, and SSAB. For additional information, see PIC (2014). Beside the author of this dissertation, three co-authors have been involved in conducting the studies presented in the appended papers. An overview of each researcher's involvement can be seen in Table 2.

Table 2 - Overview on researcher involvement.

\begin{tabular}{|c|c|c|c|c|}
\hline \multirow{3}{*}{\multicolumn{2}{|c|}{$\begin{array}{l}* * * \text { Major } \\
* * \text { Moderate } \\
* \text { Minor }\end{array}$}} & \multirow[t]{3}{*}{ Study 1} & \multirow[t]{3}{*}{ Study 2} & \multirow[t]{3}{*}{ Study 3} \\
\hline & & & & \\
\hline & & & & \\
\hline \multirow{4}{*}{ 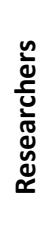 } & Waldemarsson & $* * *$ & $* * *$ & $* * *$ \\
\hline & Lidestam & $* *$ & $* *$ & $* *$ \\
\hline & Rudberg & $* * *$ & * & \\
\hline & Karlsson & & $*$ & $*$ \\
\hline
\end{tabular}

The first study was made together with Martin Rudberg and Helene Lidestam. All three researchers have been involved in all parts of the research process to various degrees. The author of this dissertation had a major responsibility in conducting the case study and presenting its earlier version of the paper on the EurOMA (European Operations Management Association) conference in Porto 2010 (Waldemarsson et al., 2010). Martin Rudberg and Helene Lidestam were for instance participating in the first company visits, several research meetings within the group, and in writing parts of the paper. Martin Rudberg took later on the overall responsibility of finalizing the conference paper for further publication (Rudberg et al., 2013), hereafter referred to as Paper 1, in which Rudberg and Waldemarsson are the first authors in alphabetic order and Lidestam is the second author.

The author of this dissertation has also had a major role in both parts of the second study, including not only the case study itself but also the conceptualization, the mathematical modelling, the scenario design, and the analytical parts, as well as in writing both the resulting Paper 2 and Paper 3. This study had a starting point in the Mill Mission model previously developed by Helene Lidestam (see e.g. Gunnarsson et al., 2007; Gunnarsson and Rönnqvist, 2008). Thus, Helene Lidestam has partly been involved in the modelling phase as well as in the writing process of Paper 2 and Paper 3. Martin Rudberg contributed partly to the overview discussions and to the writing process of Paper 2, whereas Magnus Karlsson contributed partly within discussions for analysis and in the writing process of Paper 3 . The 
earlier version of Paper 2, provided in Waldemarsson et al. (2012), was presented by the first author at the $4^{\text {th }}$ International Conference on Applied Energy (ICAE) held in Suzhou 2012. It was thereafter selected for publication in the conference special issue in Applied Energy as Waldemarsson et al. (2013a), hereafter referred to as Paper 2. The earlier version of Paper 3, provided in Waldemarsson et al. (2013b), was presented by the first author at the $22^{\text {nd }}$ International Conference on Production Research (ICPR22), held in Iguassu Falls 2013. It was thereafter submitted to a scientific journal, and is now in the first round review in its current and revised form Waldemarsson et al. (2014a), hereafter referred to as Paper 3.

In the third study, the author of this dissertation had a major role in all steps of the research and its resulting presentations. In the first part of this study, Helene Lidestam and Magnus Karlsson also contributed with for instance their presence during the first company visit, several discussion meetings, and commenting on the paper. These results are reported in Waldemarsson et al. (2014c) and presented by the first author at the $18^{\text {th }}$ International Working Seminar on Production Economics in Innsbruck 2014. The paper has thereafter been revised to its current form Waldemarsson et al. (2014b), hereafter referred to as Paper 4. The second part of this study is performed almost solely by the author of this dissertation and its result is presented in the working paper Waldemarsson (2014), hereafter referred to as Paper 5, for which Helene Lidestam and Magnus Karlsson have provided thoughtful and helpful commenting.

Beside the presented research in this dissertation the author of this dissertation has participated in a study made together with two other PhD student colleagues within PIC-Li: Johan Johansson and Martin Kylinger. In this multiple case study, the aim is to detect similarities and differences in tactical production planning among the case companies. Each author took equal responsibility in performing the study, although the paper (Johansson et al., 2011) was presented on the NOFOMA (The Nordic Logistics Research Network) conference in Harstad 2011 by the author of this dissertation. The paper has thereafter gone through some minor changes and is at current state a Working Paper (Johansson et al., 2012). This paper, together with the first two papers in this dissertation, was included in a licentiate thesis (Waldemarsson, 2012) previously defended by the author of this dissertation. Parts of this licentiate thesis have been useful when composing this dissertation, mostly related to the content in the frame of reference. The study summarized in Johansson et al. (2012) provided an overview on two of the companies studied in this dissertation and gave the authors several contact opportunities for further research. Its broad and descriptive scope fitted quite well in the licentiate thesis that held a more holistic approach. However, the content in this dissertation is aimed to be more condensed and focused, making the study summarized in Johansson et al. (2012) a bit too wide for this dissertation, although parts of it is referred to in Chapter 4 and at other suitable situations later on. 


\subsection{Methodological Summary}

In this dissertation, research from both qualitative and quantitative methodological approaches is presented. The qualitative part is represented by both exploratory and descriptive case studies, whereas the quantitative part has been done through mathematical conceptualization, modelling, solving, and analysis. Both approaches are validated in suitable ways and sufficient measures have been taken for increasing the reliability. A summary and overview of the methodological approaches used in each study and its resulting paper can be seen in Table 3.

The dissertation also analyses the papers contribution to the purpose and research questions asked. This is partly done from a rather theory building perspective based on the content of the attached papers and how they in relation to current literature can move the frontier of this field. In this process, pattern matching has been done in terms of summarizing the content of each paper and its contribution to each research question, as well as the similar from the literature found, into large tables (as e.g. Table 1). Analysis is then done by coding the content using colours for each category/topic and marking connections in-between relationships that do occur, paving the way for deeper conclusions and further contribution that can be found in utmost Chapter 6 .

Table 3 - Summary of the methodological approaches used in each study and resulting paper.

\begin{tabular}{|c|c|c|c|c|c|}
\hline \multirow{2}{*}{$\begin{array}{l}\text { Case company } \\
\text { Paper }\end{array}$} & \multirow{2}{*}{$\begin{array}{c}\text { Study } 1 \\
\text { Perstorp } \\
\text { Paper } 1\end{array}$} & \multicolumn{2}{|c|}{$\begin{array}{c}\text { Study } 2 \\
\text { Södra Cell }\end{array}$} & \multicolumn{2}{|c|}{$\begin{array}{c}\text { Study } 3 \\
\text { SSAB }\end{array}$} \\
\hline & & Paper 2 & Paper 3 & Paper 4 & Paper 5 \\
\hline $\begin{array}{l}\text { Methodological } \\
\text { design }\end{array}$ & Qualitative & $\begin{array}{l}\text { Quantitative } \\
\text { (and } \\
\text { qualitative) }\end{array}$ & $\begin{array}{l}\text { Quantitative } \\
\text { (and } \\
\text { qualitative) }\end{array}$ & Qualitative & $\begin{array}{l}\text { Quantitative } \\
\text { /Qualitative }\end{array}$ \\
\hline Methodology & $\begin{array}{l}\text { Single case } \\
\text { and } \\
\text { literature } \\
\text { review }\end{array}$ & $\begin{array}{l}\text { Mathematical } \\
\text { modelling, } \\
\text { single case }\end{array}$ & $\begin{array}{l}\text { Mathematical } \\
\text { modelling and } \\
\text { analysis, single } \\
\text { case }\end{array}$ & Single case & $\begin{array}{l}\text { Single case, } \\
\text { and numerical } \\
\text { analysis }\end{array}$ \\
\hline Case approach & Exploratory & Descriptive & Descriptive & $\begin{array}{l}\text { Descriptive } \\
\text { and } \\
\text { exploratory }\end{array}$ & $\begin{array}{l}\text { Descriptive } \\
\text { and } \\
\text { exploratory }\end{array}$ \\
\hline Study focus & $\begin{array}{l}\text { Strategic } \\
\text { Energy } \\
\text { Management }\end{array}$ & $\begin{array}{l}\text { Supply chain, } \\
\text { production } \\
\text { processes, and } \\
\text { energy system }\end{array}$ & $\begin{array}{l}\text { Planning } \\
\text { model for the } \\
\text { supply chain, } \\
\text { production } \\
\text { processes, and } \\
\text { energy system }\end{array}$ & $\begin{array}{l}\text { Production } \\
\text { process and } \\
\text { energy } \\
\text { system } \\
\text { interactions }\end{array}$ & $\begin{array}{l}\text { Planning of } \\
\text { production } \\
\text { process with } \\
\text { high energy } \\
\text { impact }\end{array}$ \\
\hline
\end{tabular}




\section{Frame of Reference}

In this chapter I will go through some concepts and relevant literature for the context of this dissertation. Some characteristics for process industries are explained followed by a section about managing industrial energy. We will also look into some managerial aspects of planning production and supply chains per se, as well as the concept of including energy issues when planning production and supply chains. However, let us begin with explaining and defining some of the most used concepts and keywords in the framing of this dissertation.

\subsection{Defining the scope}

Since this dissertation involves concepts from both a production process perspective and an energy system perspective, these concepts need to be positioned according to their use and meaning in this dissertation. I will start with defining the main fields: Operations Management (OM) and Energy Management (EM).

Chase et al. (2007, p. 9) define Operations Management as "the design, operation, and improvement of the systems that create and deliver the firm's primary products and services". They argue that we have labour, capital, natural resources, constructions, machines, material, and energy on the input side, whereas goods and services are found on the output side. In between there are transformations in the form of operations (Chase et al., 2007). From this point of view, both the production processes and the energy system processes should thus be covered by the field of Operations Management, as suggested while framing the scope of this dissertation (Figure 2). In addition, APICS (2008) also includes planning, scheduling and control of these transformations (or operations) as important elements for the field of Operations Management. An "operation" could moreover according to APICS $(2008$, p. $90 ; 103)$ be considered as "the intentional changing of an object in any of its physical or chemical characteristics" whereas a "process" is considered to be "a planned series of actions or operations". For instance, the process for hot rolling steel contains (simplified) operative actions for heating, roughing, rolling, cooling, and coiling. There is thus a difference between "operations" seen from an organisational point of view as "the group 
that produces the goods and/or services that a company sells" and an "operation" that in addition to previous considerations also can be seen from a process point of view as an activity in terms of "a job or task, consisting of one or more work elements, usually done essentially in one location" (APICS, 2008, p. 90-91). The delivery of products and services to the end customers is finally done through a (possibly global) network in terms of a supply chain (APICS, 2008).

As previously indicated in Figure 2, large proportions of Energy Management could be seen as subsets of Operations Management. Per se, the definition of Energy Management is very much similar to the definition of OM. According to O'Callaghan and Probert (1977), Energy Management involves monitoring, measuring, recording, analysing, critically examining, controlling and redirecting energy and material flows through systems. However, these management activities could preferably also be done with respect to the quality of energy, or exergy, as well as the economic side of energy efficiency and effectiveness. Consequently, there are also parts of the field of Energy Management, such as issues more related to thermodynamics and physics, which could be positioned a bit outside the scope of Operations Management.

The fields of $\mathrm{OM}$ and EM are in this dissertation further narrowed down to a production process perspective and an energy system perspective. These perspectives, and especially their intersection, are considered to build the foundation on which the involvement of energy issues into planning of production and supply chain can make a difference. A production process is considered to be the "activities involved in converting inputs into finished goods" (APICS, 2008, p. 107). Such activities could in this dissertation be exemplified as pumping, heating, cooling, cutting, mixing, forming, rolling, painting and packaging. An energy system is considered to be an interrelated network connecting energy related activities where entropy increases as energy is transformed (used) and work is extracted. An energy system can thus contain for instance fuel burning facilities, steam-boilers, exhaust gas recycling equipment, electricity generators, electricity transfer equipment, steam pipes, heat transfers and electricity engines, etc. In this context one can say that the production processes and the energy system partly set the rules of the game in which the involvement of energy issues into planning of production and supply chain is a part of the procedure of the game. To position some additional words and concepts related to the rules of the game, the author of this dissertation hence suggests a structure as presented in Table 4. Whereas workforce is one of the main inputs to a production process, energy can be considered to result in the workforce an energy system can provide. Work can then be done by utilizing electricity and heat in machines and production equipment. Whereas the amount of useful energy can be measured in terms of exergy, the value added corresponds to the amount of useful work applied. As such, the gap between the exergy consumed and the exergy needed (comparable to the energy efficiency gap), or the work applied and the value achieved, can be considered as the amount of waste generated in each perspective. 
Table 4 - Suggested concept overview of Energy System and Production Process.

Category\Concept

Unit of concept

Typical utilization unit

Qualitative measurement

Waste is the gap between:

\section{Energy System}

Energy

Electricity and heat

Exergy (qualitative energy)

Exergy used and Exergy needed
Production Process

Work (production)

Man, machine, equipment

Value adding (qualitative work)

Work and Value

Nevertheless, not everything made or produced in industries are of primary interest. Beside main products, also by-products and co-products appear, especially in the commonly divergent flows of process industries. The difference between a by-product and a co-product is in this dissertation that a co-product is supposed to exist; it brings value by purpose although it does not have the same priority as the main product(s). A by-product, on the other hand, is something that normally is not whished for, although it may not bother anyone whereas higher proportions of some compared to others could be preferred. Byproducts are yet something that needs to be dealt with, but seldom prioritised. If a market can be located for the by-products, they can be upgraded to co-products and hence build alternative revenue. This problem situation could moreover be debated regarding the question of what is core for business in a company. According to APICS (2008, p. 27), core competence "enable a firm to provide the greatest level of value to its customers in a way that is difficult for competitors to emulate and that provides for future growth" but is "not directly related to the product or market". In line with Prahalad and Hamel (1990), management have the task to administer the core competence and how it relates to customer benefits, but also to opportunity losses if specific competences is viewed upon as unnecessary and thus will fade away.

Planning is one of the managerial issues of production and supply chains. In this context, planning is about setting goals and to determine how to utilize resources in order to accomplish these goals. As such, production planning has the intermediate range objective to optimize the utilisation of resources as a response to forecasted demand (Taylor et al., 1981b). It is thus a "process to develop tactical plans" to meet "business objectives of profitability, productivity, competitive customer lead times, and so on, as expressed in the overall business plan" with the purpose to set production rates to satisfy the customer demand according to management's objectives (APICS, 2008, p. 107). Supply chain planning has moreover the managerial task to determine "a set of policies and procedures that govern the operation of a supply chain" and that among other things includes quantities and timing aspects as well as policies for inventories and production (APICS, 2008, p. 135).

\subsection{Process Industries}

As previously stated, most things around us in our daily life have been processed in one way or another through a process industry. Process industries are as such basic converters positioned early in the value chain (Finch and Cox, 1987; King, 2009). They add value by mixing, separating, forming, and/or through chemical reactions (APICS, 2008, p. 104) 
through processes in terms of pipeline, chemical, refining, food processing, or metal processes following a batch or continuous mode (APICS, 2008). Both continuous production and batch production can as such be distinguished among process industries (Kallrath, 2002b). There are several meanings of the batch concept in the industrial context. However, for the process industries investigated in this dissertation a batch distinguish the quantity in terms of for instance number of items, tons, or cubic meters of a product produced (or product group produced, where the products are similar enough to be treated as a homogenous group in the specific production process). Several batches can be sequenced in a series and as such grouped into a campaign. If the overlap between the batches or even the campaigns is done without interruptions in the production flow we have a continuous process running, not only during each batch but also in-between them. The products produced in process industries typically exist in the form of powder, gas, or in fluent forms that normally becomes discrete during packaging. In Figure 5, several of the above mentioned characteristics for a process industry are exemplified through a fictive cookie factory. Let us in this example assume that Linus is going to make cookies using a continuous flow from the pouring of ingredients to the forming of each cookie where the product in one sense becomes discrete. All the way through the boiling process (P1), the mixing process (P2) and the process where chemical reactions take place (P3); the flow of material is continuous. However, even though each cookie is a discrete unit during baking and cooling these processes are nevertheless made in a continuous mode and the final and countable product should in this case be considered as the jar of cookies. In the campaign scheduled today, Linus want to produce three different type of cookies by using three different recipes, each requiring specific amounts (and/or other specifications) of the three different ingredients a, $b$, and $c$. As such, three different batches of cookies are made in this campaign following the sequence: $\mathrm{B} 1, \mathrm{~B} 2$, and $\mathrm{B} 3$.

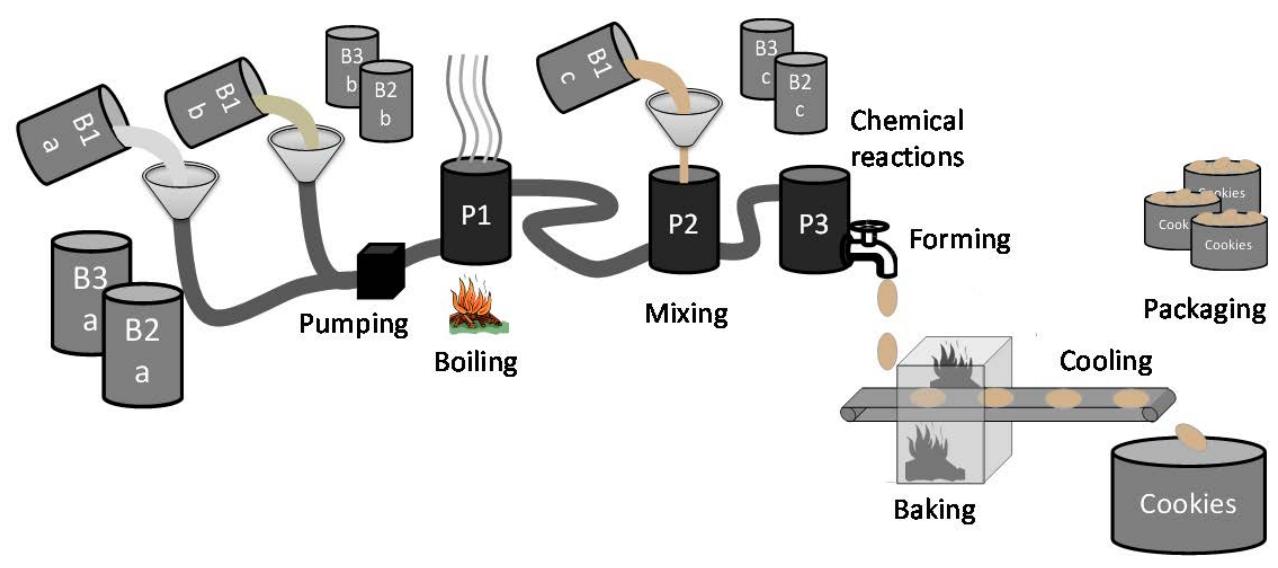

Figure 5 - Process industry cookie making (fictive example for illustrative purpose).

With the continuous process running even during the changeovers in-between the batches within this campaign, the first cookies of batch 2 and 3 (B2 and B3) will have some 
characteristics similar to the cookies in the first and second batch respectively, and will probably be sold as second grade cookies to the market for this reason. After this campaign, Linus plans for another campaign to take place with perhaps other type of cookies. Depending on the preferences and requirements on the products planned to be produced in the next campaign, a setup might be required for cleaning the process equipment or for perhaps maintenance to take place. However, setups could also take place in-between batches if beneficial to do so.

Linus produces cookies that have a high volume demand on the market, and he does this in a process industry environment as exemplified in Figure 5 in order to keep the average costs down. However, Linus has a cousin Linnea who lives across the village, and she produces more exclusive cookies than Linus. Since Linnea's cookies are made in lower volumes, and often according to more specific customer requirements, she uses another type of manufacturing process than Linus by making them mostly by hand herself. Linnea also spends a large amount of time on each cookie, and the more exclusive cookies Linnea makes therefore have a quite high value to weight ratio. Nevertheless, most process industry products, like the cookies Linus produces, are rather found in the other end of this scale, with a low value to weight ratio on the products (Fransoo and Rutten, 1994). Therefore, process industry companies often experience relatively high costs for transportation of their products (Taylor et al., 1981a). Production equipment is rather capital intense and used in mostly flow orientated production (Taylor et al., 1981a), and can be exemplified with that Linus has invested a lot more capital in for example pipes, pumps, boiling equipment, unique containers for different production steps, and in automatic packaging than his cousin Linnea who does most of the work by hand using simple baking equipment in her standard kitchen. Due to large investments for additional or more efficient process equipment, the capacity of Linus's cookie factory is often lagging the demand for his cookies, providing the main production objective to maintain a high utilization of his resources, which is typical for process industries (Olhager et al., 2001). Process industries also often consider large risks concerning their location (Taylor et al., 1981a), and it is often difficult to be both close to the raw materials as close to the market. In terms of layout, process industries are traditionally positioned in the lower right corner in the product-process matrix (Hayes and Wheelwright 1979a; Hayes and Wheelwright, 1979b). Flexibility can in general be reached in two ways: volume flexibility by increasing/decreasing throughput or mix flexibility by dividing capacity between different products (Fransoo, 1992), although volume flexibility in general is difficult to achieve for process industries (Fransoo and Rutten, 1994). In Linus's cookie factory it is to exemplify easier to produce more of batch 1 and less of batch 2 than to increase the speed of production, since it already run for almost full capacity. Yet, choice of flexibility, product diversity, and equipment dedication, as well as responsiveness to rush orders with respect to scheduling sequences, are considered as important decisions to make (Taylor et al., 1981a).

For capacity utilization reasons, process industries tend to first schedule capacity and then materials (Taylor et al., 1981a). As such, the planning process in process industries is often 
capacity oriented applying a Make-To-Stock (MTS) strategy (Fransoo and Rutten, 1994). For Linus and his cookie factory he could for example apply a cyclic planning approach (Doll, and Whybark, 1973; Ashayeri et al., 2006; Olhager and Persson, 2006), further described in chapter 3.4, and use buffers in inventory (stock) to cover quantity related uncertainties in demand. But process industries can also be material dominant and practise more Make-toOrder (MTO) or Assemble-to-Order (ATO) (Dennis and Meredith, 2000). Therefore, the product can be interchangeable up to a specific stage in production (Mallya et al., 2001). Many process industries also experience vast benefits with tailor-made cyclic planning, especially regarding recycling flows (Ashayeri et al., 2006). Taylor et al. (1981a) present two typical strategies for process industries to handle inventory: setting production rate equal to demand, or running for full capacity and periodically shut down. Regarding for instance energy costs, the latter one is often preferred. Planning problems commonly also relate to the raw materials and their natural variations in quality, and thus variations in the bill of materials (Taylor et al., 1981a), as well as seasonal varying prices (Mallya et al., 2001).

Process industries are also energy intensive with energy costs around $10-20 \%$ of the total costs (Thollander and Ottosson, 2010). They top the list of energy usage per added value (Stratton, 1979) and must consider long range energy plans in order to ensure that pollutants stay within the limits of environmental laws (Taylor et al., 1981a). The capacity domination, energy intensity, and raw material complexities also have a larger impact on planning in process industries than in other manufacturing industries (Taylor et al., 1981a). For instance, by-products or co-products that are produced in proportion to chemical and natural characteristics can with an uneven demand of one product result in large inventories or limited production of the other (Taylor et al., 1981a). Even though the production phase is dominant in the energy intensive process industry, supply chain decisions can have significant impact on the use of energy (Kalenoja et al., 2011). If for example Linus could use the steam from his boiling process (P1) to his neighbour's spa and their sauna, he would have additional revenue possibilities from steam as a co-product.

\subsection{Managing Industrial Energy}

Accessible energy supply can be measured by an available capacity to perform work. For instance, the more electric energy your battery has the longer distance your electric vehicle can transport you. There are several forms of energy such as kinetic energy, thermal energy (heat), potential energy, electromagnetic energy (energy radiation, e.g. light), electrical energy (electricity), and nuclear energy. Energy can neither be created nor destroyed; therefore the total energy of a system remains constant, since energy use may result in transformation into one or more of the other forms and, as such, from a high quality form (low entropy) to lower quality form (high entropy), according to the principles of thermodynamics. The quality dimension of energy can be referred to as exergy, which is the ability to be useful energy with respect to the surroundings. 
When managing industrial energy it is also relevant to make a distinction between the context of energy efficiency and the context of energy effectiveness. Efficiency in general can be considered as a measurement in percent of actual output in relation to the expected output, whereas productivity is a measurement of output in relation to input (APICS, 2008). As such, the energy efficiency of an electric vehicle relates to how well the electric energy content of the battery is transformed into kinetic energy to put the vehicle in motion, whereas the productivity of the electric vehicle can be measured in distance travelled per unit electricity consumed (e.g. $\mathrm{km} / \mathrm{kWh}$ ). Whereas efficiency is about doing things right, effectiveness is on the other hand about doing the right things, such as going to the right place and following the shortest path with your electric vehicle. If you in addition can choose between different energy carriers with different exergy levels as input for your vehicle, and that this is done in an energy system where other activities compete about the energy carriers, energy effectiveness is about selecting proper energy carriers for each participant in the energy system so that the total exergy waste is minimized. From this point of view, energy efficiency strives to minimize waste at a specific activity, whereas energy effectiveness strives to minimize waste between and/or among several activities. However, for a series of actions viewed as one process with an expected output of some kind, both energy efficiency from an internal point of view and energy effectiveness from an external point of view could be applicable dimensions for performance measurements of such process. The specific measurement in each case hence depends on the level of point of view relative to the energy system boundaries applied.

With respect to the thermodynamic potential, the energy efficiency gap reaches $80 \%$ of today's energy use, yet with respect to the technological potential available today it still reaches $50 \%$, at least according to Hammond (2007). The techno-economical potential is however much smaller due to tough competitiveness on the energy market. There are also organisational barriers to energy efficiency investments worthy to consider in this context (Cooremans, 2012). These barriers are summarized in four levels by Cooremans (2012, p. 514): the "Base Barrier" concerning information and lack of knowledge, the "Symptom Barriers" concerning mistaken interpretations of hidden costs and risks, the "Real Barrier" concerning lack of strategic drive, and the "Hidden Barrier" concerning cultural dimensions that affect decisions in a subconscious way. In many cases it is nevertheless worthy to retrofit a plant or rebuild it with more respect to the laws of thermodynamics among the production unit activities, as Wolters et al. (1995) suggest. In Linus's cookie factory seen in Figure 5, there are for example large heat-losses at the boiling process and in the exhaust gases from the baking process. To for instance use the exhaust gases from the baking process as heat input to the boiling process, and consequently decrease or even eliminate the need of fuel for that process, could be one techno-economical and thus cost-efficient way to increase the energy efficiency of each process and the overall energy effectiveness within his factory. In fact, decreasing cost is the main motive for most companies to reduce the use of energy (Christoffersen et al., 2006). However, to take the step even further, Linus could instead of using fuel for his baking process perhaps sell the fuel to the close-by 
Combined Heat and Power (CHP) facility (or not buy the fuel in the first place) and instead use a combination of hot water, steam, and electricity delivered by the CHP to his energy demanding processes, with respect to the exergy requirement of each process. However, even though this to a vast degree is technically possible, such solution might require large investments, and could be considered too costly and risky for Linus to choose, and thus not economically beneficial for him. For the energy intensive industry, rising prises of for instance electricity is crucial and according to Thollander et al. (2009) also considered to be one of the greatest threats to their long-term survival. The great importance involved regarding the strategic dimensions of energy issues, and which road to take, is therefore still valid (Lovins, 1976). Yet, energy management practices is not that frequently common in the industry, according to Christoffersen et al. (2006) and their study of the Danish industry. To decide if a company practices energy management, Christoffersen et al. (2006, p. 517) set a list of energy management practices they require the company to fulfil, and accordingly the company must: "put forward an energy policy" and; "establish quantitative goals for energy savings or should have objectives concerning implementation of specific energy-saving projects" as well as; "have implemented specific energy-saving projects originating from the energy management". Christoffersen et al. (2006, p. 518) also have a supplementary list out of at least one need to be fulfilled: "systematically make energy-efficient purchases following a specified procedure" and/or; "organise energy activities by clearly allocating responsibility and tasks" and/or; "seek to actively involve the employees in the work of energy saving by informing, motivating and finally educating them". To conclude, there are several energy management practices a company could apply in order to work with energy management. This is further analysed in Paper 1 of this dissertation, where the necessary prerequisites for putting energy management on the strategic agenda is moreover investigated.

Nevertheless, energy issues can also be a matter of competitiveness for many energy intensive process industries, especially for the pulp and paper industry (Carlsson et al., 2009), where optimization of the energy flows also is important (Marshman et al., 2010). An optimal energy mix from an economic point of view is thus an important decision problem for process industries (Arivalagan et al. 1995). For instance, the increasing importance of bioenergy is addressed by Gunnarsson et al. (2004) regarding such supply chain modelling situation. The issue is also about to utilize existing energy resources in an optimal way (e.g. Arivalagan et al., 1995) and correctly practicing the concepts of system boundaries (e.g. Kalenoja et al., 2011). For such matters great opportunities can be found in regional cooperation where electricity, steam, and heat can be beneficially traded among the participants (Klugman et al., 2007).

\subsection{Managing and Planning Production and Supply Chains}

Stadtler and Kilger (2008) enlighten the importance of advanced planning, process orientation and support for information and communication in order to achieve competitiveness with your supply chain. According to Fisher (1997), an efficient supply chain focuses on throughput, capacity utilization, and cost minimizations, which are strategies that 
usually match very well with process industries. However, the market is not deterministic and demand changes over time. Managing and planning the production and the supply chain is thus a difficult task for particularly process industries, especially due to their industry specific requirements and restrictions for scheduling (Loos and Allweyer, 1998). However, there are managerial means to make these planning processes comprehendible, and for the remainder part of this chapter, I will go through some of its related issues.

\subsubsection{The strategic, tactical, and operational point of views}

Decisions within a company can be divided into different levels: strategic, tactical, and operational. The border between strategic, tactical, and operational planning can however be diffuse, as argued by Kallrath (2005).

A strategy is a set of plans and policies, aiming to gain competitive advantages. A successful manufacturing strategy strives for productivity, but should not be too narrow in its focus, and should also consider other aspects beside low costs and high efficiencies (Skinner, 1969). From a strategic point of view it is important to match products produced with processes used, and such matching can be done with support from product profiling (Hill and Hill, 2009), and the product-process-matrix (Hayes and Wheelwright, 1979a; Hayes and Wheelwright, 1979b). Process industries with continuous flows thus typically match with standard products with a narrow product range and large customer order sizes. The overall key operations task of most process industries is low cost production (Hill, 2000). As such, price is a typical order winner, and there is in general a low rate of new product introductions since it is of general advantage to have a dedicated process technology, where lower process flexibility is thus allowed. It is also common to produce large lot sizes with few setups, at a relatively high cost per setup. Mohanty and Deshmukh (1998) argue that green manufacturing is a new paradigm in the manufacturing strategy context. However, highly developed energy efficiency could nevertheless be a competitive advantage for some industries (Carlsson et al., 2009). A strategic planning horizon is in this context covering long term events and risks where decisions focus on ensuring the company long term survival. Strategic planning is thus the "process of developing a strategic plan" for "how to marshal and determine actions to support the mission, goals, and objectives of an organization" (APICS, 2008, p. 132).

Carlsson et al. (2009) presents in a matrix how supply chain planning problems, divided into strategic, tactical, and operational levels, also can be separated into procurement, production, distribution and sales activities. As such, Carlsson et al. (2009) enlightens planning problems that very often occur along the supply chain for the pulp and paper industry, and address energy supply as a crucial and strategic factor. Nevertheless, tactical planning is normally done within production planning and/or sales and operations planning to link the mid-term (tactical) planning level to the strategic plan (APICS, 2008). The tactical plan should specify capacity levels and production levels, among other things, for "achieving the intermediate goals and objectives to support the organization's strategic plan" (APICS, 
2008, p. 136). On a shorter time horizon we finally have the operational planning with the task to develop "short-range plans and schedules detailing specific actions"..."constrained by and targeted for achieving the strategic and tactical plans" (APICS, 2008, p. 90).

\subsubsection{Capacity Utilization and Investments}

Since most process industries are capital intensive and heavily invested in production equipment, the issue of capacity utilisation is very often a high priority. Capacity is therefore an important and strategic issue for many process industries and a structural decision category that depending on long term changes in demand calls for adjustments (Buffa, 1984; Fine and Hax, 1985; Olhager et al., 2001). The results of previous strategic decisions regarding capacity, based on previous forecasts on long term demand, can in one way or another thus be seen in the capacity utilisation of today. As such, a company can choose the strategy to lag, track, or lead in capacity, and combine this with sales and operations planning strategies such as level, mix, or chase, as presented in the framework by Olhager et al. (2001). From an historical point of view, process industries tend to lag in capacity due to their capital intensiveness, and they very often practice a levelling planning strategy partly due to the common lack of volume flexibility. However, mix flexibility can be achieved through agile planning approaches, but not without the price of decreased volume during the setup times. There is also of great importance to focus on the bottle neck when capacity lag. For this we can assume that the bottle neck in Linus's cookie factory can be found in the baking process, since each cookie need a specific time in the oven. Investments in a more efficient oven or a larger oven with longer transportation band could thus increase the throughput of the whole factory.

Beside the dependency between capacity and flexibility, there is a strong connection to investment issues regarding how to obtain additional capacity and/or flexibility. This is highly relevant when it comes to the issue of decreasing supply risks of for instance energy. For all investments, decisions need to be made and when evaluating different alternatives, the importance of assumptions should not be neglected (e.g. Borgonovo and Peccati, 2006). Reliable data and accurate cost and benefit analysis (e.g. Tang and Tomlin, 2008), is however more trustworthy than assumptions and makes therefore the firm more obedient towards suggested investments. According to Cooremans $(2011 ; 2012)$ there are also other characteristics than profitability that matters in the choice of investments for energy efficiency, by putting the investment decision in relation to the competitive advantages related to value, cost and risk. Cooremans (2011) also argue that the strategic character of an investment has major influences the decision-making. However, no matter if the decisions involve operative and tactical planning or more strategically related investments there is nevertheless a certain need for suitable models and decision support for their evaluation. 


\subsubsection{Modelling and Optimization}

The scientific field for mathematical modelling and optimization is huge and could take plenty of pages or even books to describe. In this chapter I will thus go through some of the basics concepts and parts of the field in order to connect to the research done in this dissertation. As such, modelling refers to the process of mathematically describing the structure of a real industrial problem. Optimization refers to the process of selecting the optimal (best) elements from a set of available alternatives under the constraints of some criteria(s), preferably by using a mathematical programming model for the problem. There are several different kinds of linear or nonlinear mathematical problems that can be optimized, given the right circumstances. One mathematical method for solving linear problems is Linear Programming (LP) that was developed during the Second World War, where the simplex algorithm, first published by George Bernard Dantzig in 1947, is one of the most common algorithms used in solving LP problems (e.g. Wood and Dantzig, 1949; Dantzig, 1949; Dantzig, 1955). According to Dantzig (1963) there are four basic assumptions to consider when formulating a LP model: "Proportionality" (proportional transformation), "Nonnegativity" (negative quantities not possible), "Additivity" (balance of flows), and "Linear Objective Function" (positive or negative contribution depending on activity). A general LP problem can be formulated as:

$$
\begin{aligned}
& \min z=\sum_{i=1}^{n} c_{i} x_{i} \\
& \text { s.t. } \sum_{i=1}^{n} a_{i j} x_{i} \leq b_{j}, \quad j=1, \ldots, m \\
& x_{i} \geq 0, \quad i=1, \ldots, n
\end{aligned}
$$

This is a minimization problem but optimization problems can also be formulated as maximization problems, as the following simple and fictive example: Assume that Linnea is going to the market to sell apples and oranges today. At the moment she has 6 apples and 5 oranges available at home. At the market she can sell apples for 4 SEK each and oranges for 5 SEK each, and because the demand for both apples and oranges is large at the market she expects to sell everything she brings. She will use her knapsack to carry the fruit to the market, and because of the distance she can only go once today. Linnea can at most carry $1.8 \mathrm{~kg}$ fruit to the market or as much that there is room for in her knapsack, with the available volume of 2.8 litres. One apple weighs about 200 grams (g) and needs a volume of about 350 millilitres $(\mathrm{ml})$, whereas one orange weighs about $300 \mathrm{~g}$ and needs a volume of about $400 \mathrm{ml}$. The problem is now to decide how many apples $\left(x_{1}\right)$ and how many oranges $\left(x_{2}\right)$ she should carry to the market today in order to maximize her sales $(z)$. The problem can be formulated or modelled as: 


$$
\begin{aligned}
& \begin{array}{rr}
\max & z=\begin{array}{r}
4 x_{1} \\
\text { s.t. }
\end{array} \quad 5 x_{2} \\
200 x_{1} & +300 x_{2} \leq 1800 \quad \text { (weight) }
\end{array} \\
& 350 x_{1}+400 x_{2} \leq 2800 \quad \text { (volume) } \\
& x_{1} \leq 6 \quad \text { (number of apples) } \\
& x_{2} \leq 5 \quad \text { (number of oranges) } \\
& x_{1}, x_{2} \geq 0 \quad \text { (non-negativity) }
\end{aligned}
$$

This problem has only two variables, $x_{1}$ and $x_{2}$ and can easily be solved by graphic methods, as shown in Figure 6. The optimal solution under these conditions is thus given by the intersection of the weight constraint and the volume constraint where $x_{L P}^{*}=\left\{\begin{array}{l}4.8 \\ 2.8\end{array}\right\}$ with the sales $z=33.2$ SEK (left part of Figure 6). However, if Linnea only can bring whole apples and oranges, the $x$-variables need to be integer and we thus have an Integer Programming (IP) problem (e.g. Lenstra, 1983; Williams, 2009) with the optimal solution $x_{I P}^{*}=\left\{\begin{array}{l}3 \\ 4\end{array}\right\}$ and a sales of $z=32$ SEK. As can be seen in the right part of Figure $6, x_{I P}^{*}$ is the last point with whole apples and oranges that the objective function passes in the allowed area, and $x_{L P}^{*}$ is not feasible in the IP problem. The optimal solution $x_{I P}^{*}$ is also on the border of the weight constraint, as can be proven by testing it: $200 * 3+300 * 4=1800$. It is also notable that even though the feasible point $x=\left\{\begin{array}{l}4 \\ 3\end{array}\right\}$ is closer to $x_{L P}^{*}$ in terms of coordinates, the sales it provides $\left(z=31 \mathrm{SEK}\right.$ ) is still less than what achieved with $x_{I P}^{*}$. Linnea should to conclude bring 3 apples and 4 oranges to the market in order to maximize her sales (unless she thinks she can sell fractions of the fruit).
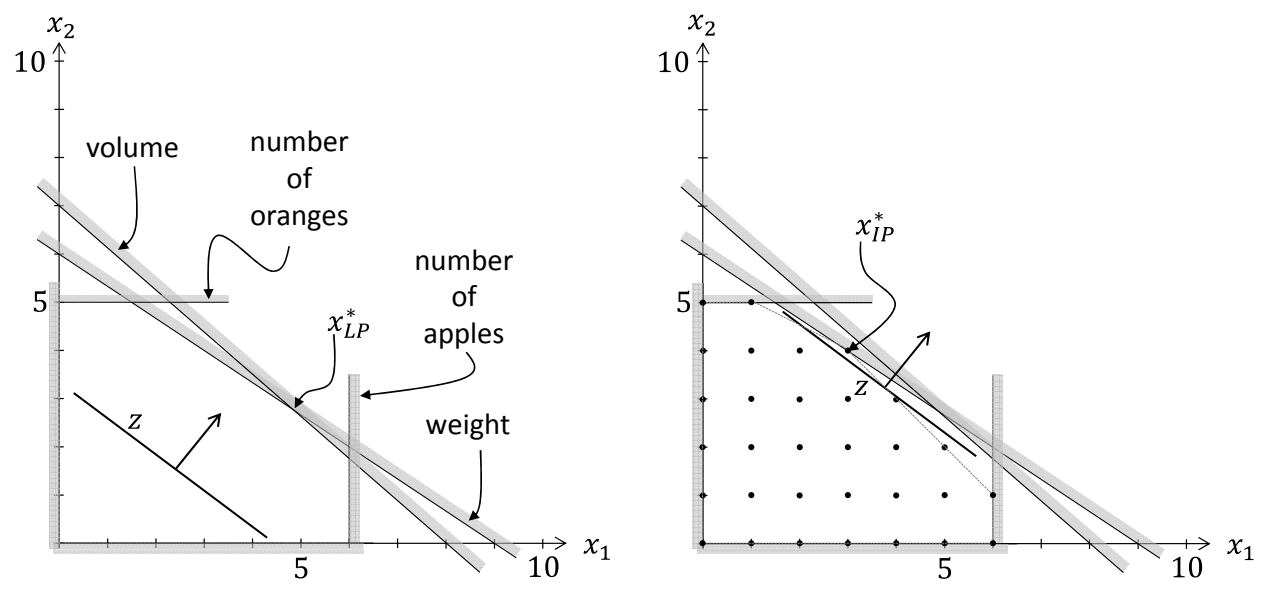

Figure 6 - Fictive example of a simple LP-problem with continuous variables (left) and an IPproblem with integer variables (right).

If a variable only can have the values of 1 or 0 we have a binary variable, which is a special case of the integer variable, and the second one of Karp's 21 NP-complete problems, where nondeterministic polynomial (NP) problems, compare to polynomial (P) problems, are 
viewed upon as difficult to solve (e.g. Karp, 1972; Cook, 1971; Zuckerman, 1996). A binary problem could be exemplified with a situation where Linnea has to choose between two knapsacks with different volume capacities and different costs for using. If we have a mixture of continuous, integer and/or binary variables we have a Mixed Integer Linear Programming (MILP) problem (e.g. Kondili et al., 1993; Arivalagan et al., 1995; Kallrath, 2002a; Karlsson, 2011). The Energy Mission model presented in Paper 2 and Paper 3 contains both continuous and binary variables and is thus formulated from a MILP problem perspective. The Energy Mission model is explained more in detail further on, but to shortly relate to the exemplified situation for Linnea, we choose to produce several different pulp products to sell instead of apples and oranges, and choose between different recipes for production instead of choosing between different knapsacks. There are also plenty of other variables and constraints to consider in the Energy Mission problem that increases its complexity. There are for instance multiple factories for volume allocation, which could be compared with a situation where Linnea would have brothers and sisters to help her carrying fruit to the market. The Energy Mission model could however be more useful for Linus and his cookie factory earlier described. If Linus beside steam from the boiling process also could utilize excess heat from the cooking process to produce hot water and sell it to the nearby cafeteria, and that some cookie recipes would result in more hot water than others, then Linus could maximize his revenues depending on both the demand of cookies and the cafeteria's demand of hot water, as well as the steam demand from the sauna previously mentioned. If it in addition will be a trade-off between steam and hot water, the complexity of the problem increases.

Other problems can result in non-linear mathematical models. If we for example refer back to Linus's planning problem of producing three different types of cookies in his factory, there are several approaches for him to take on. Let us assume that the demand for all of these cookies is relatively high and constant over time, a cyclic planning approach (e.g. Doll and Whybark, 1973; Olhager and Persson, 2006) would hence be to prefer in Linus's cookie factory. If we also assume that the production rates are higher than the demand rates, the task is then to determine for how long time each batch should be scheduled for production, in other words the size of each batch. When running batch 1 (B1) we increase the inventory level of this type of cookies since the demand rate is lower than the production rate. The accumulated inventory during the time of production for this batch should then be enough to cover the demand until the next batch of the same type of cookies is initiated in production. The time of each such cycle is referred to as the cycle time $\mathrm{T}$, as seen in Figure 7. It is also assumed that a setup (for cleaning the equipment) is needed before each batch.

Since there is a holding cost $\mathrm{H}$ for inventory in terms of capital-tied-up among other things, and since there is also a setup cost $\mathrm{K}$ in terms of for example an opportunity cost for production, there is altogether a problem to minimize the total costs with respect to the cycle time chosen. The economic cycle time will then minimize the total cost for inventory and setup, formulated as: 


$$
C_{t o t}=\sum_{i} K_{i} \frac{1}{T}+H_{i}\left(1-t_{i} D_{i}\right) \frac{D_{i} T}{2}
$$

where $T$ is the common cycle time, $t_{i}$ is the production time for batch or product $i, K_{i}$ is the setup cost for product $i$, and $D_{i}$ is the demand rate for product $i$. The economic cycle time is then derived from the cost function as:

$$
T^{*}=\sqrt{\frac{2 \sum K_{i}}{\sum H_{i} D_{i}\left(1-t_{i} D_{i}\right)}}
$$

A feasibility check is then necessary to ensure that for instance the capacity has enough room for both setup times and production time. Using $s_{i}$ as the setup time for product $i$ we have:

$$
T_{\text {min }}=\frac{\sum s_{i}}{1-\sum t_{i} D_{i}}
$$

The optimal common cycle time is then chosen as:

$$
T_{\text {opt }}=\max \left\{T^{*}, T_{\min }\right\}
$$

And the batch size or quantities of each product can be determined as:

$$
Q_{i}=T_{o p t} D_{i}
$$

The above described procedure to minimize setup costs and inventory holding costs with respect to a common cycle time for all products made is for a general form of this problem (e.g. Doll and Whybark, 1973; Olhager and Persson, 2006). 


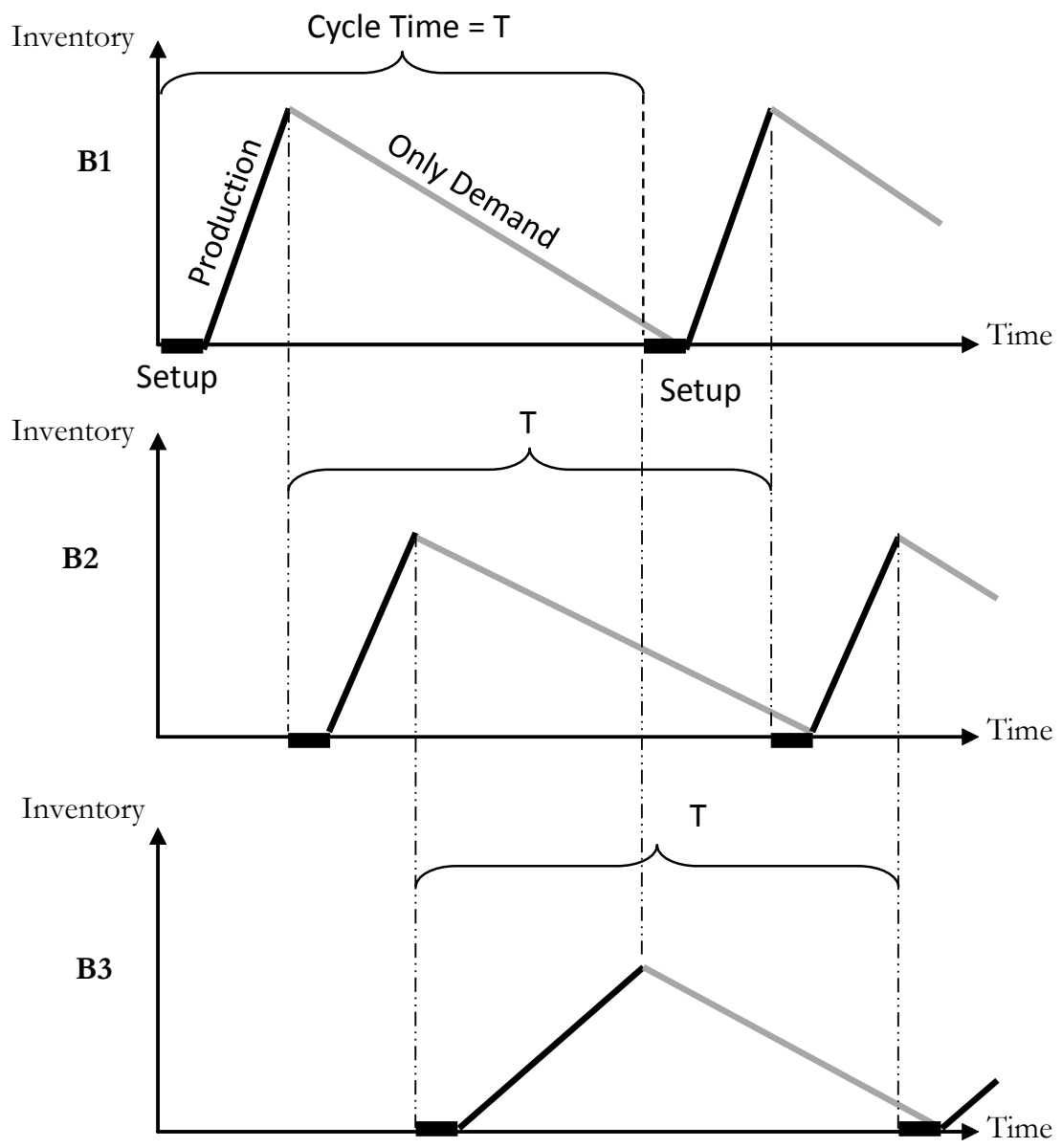

Figure 7 - Expected inventory levels of each of the three types of cookies if Linus apply a cyclic planning approach on planning the cookie production in his factory (fictive example).

\subsection{Including Energy when Planning Production and Supply Chain}

In utopia, all operative activities, all products made (including by- and co-products), and everything necessary for the value adding processes, should be involved when planning and managing both production and supply chain. However, considering everything within a company, and all external factors that affect the production and its supply chain, will require tremendously large and complex models. Such models will most likely be almost impossible to solve to optimality within a decent time frame. Instead, focus should rather be on selecting the most important and relevant factors for including in the planning stage. For instance, when strategic decisions about industrial energy systems should be made, the literature suggests to involve the entire plant in such decision making (e.g. Bengtsson et al., 2002; Tari and Söderström, 2002; Karlsson, 2011). The production planning processes also 
involves important energy efficiency decisions (Kalenoja et al., 2011). The energy efficiency of a supply chain is according to Kalenoja et al. (2011) moreover affected by decisions made regarding for instance scheduling, operations strategy, and demand response. The energy issue is not new for production planning or supply chain planning, however few examples found in the literature spend specific attention to energy issues in these fields, indicating that the energy focus has from an operations management point of view traditionally been in the shadow of many other priorities. Nevertheless, a decision support tool for the supply network planning of a chemical industry, using linear programming optimization, has been developed by Grunow and Günther (2008). In their model they involve the use of alternate production resources and production of by- or co-products such as electricity, and the model has also been proven to be of major value for both strategic and operational decisions. Logically, similar models in comparable or even more energy intensive industries should thus be needed.

The production network and the supply chain for the case company investigated in the second study of this dissertation have been studied several times before. Carlsson and Rönnqvist (2005) present a general overview and discuss the decision support tools used for the company's supply chain planning. Gunnarsson et al. (2006) further on analyse the distribution planning problem and include routing issues as well as terminal locations in a mixed integer programming model. The whole supply chain is later on considered by Gunnarsson et al. (2007) that also present a model (Mill Mission) with a one year planning period. The Mill Mission model is further developed by Gunnarsson and Rönnqvist (2008) by also considering multiple time periods and the use of heuristics. The same authors, Lidestam and Rönnqvist (2011), later on study the same supply chain and develop a mixed integer linear programming model, for which a Lagrangian heuristic method based on Lagrangian decomposition is used to solve the supply chain planning problem. Yet, despite the vast energy intensity of this pulp company, none of these studies mentioned have taken any special consideration to energy issues per se, leaving an open door for additional research.

\subsubsection{Complex Planning Issues around Energy}

Since energy carriers such as steam and electricity is difficult to store in vast amounts, compared to their origin in different fuels (Grubbström and Hultman, 1989), the need for flexibility on the energy demand side stresses the energy supply system on different levels. To exemplify, heat is volatile and difficult to store, and electricity needs to be consumed at the exact moment as it is produced (Grubbström and Hultman, 1989). This leads to that demand uncertainties in terms of quantity are problematic to handle by using safety stock or inventory of energy carriers. For example, the steam demand Linus and his cookie factory experience could be highly seasonally dependent and very concentrated to winter. Therefore, a more flexible input side of storable energy commodities is needed, especially when the demand or output side is difficult to forecast. Such strive for flexibility is thus likely to increase for example shortage costs, ordering costs, setup costs, and holding costs (Khouja, 1999). Tari and Söderström (2002) as well as Karlsson (2011) also look at the 
problem of energy storage in terms of system optimization in a case study of the pulp and paper industry, where material storage is included into the MILP model used in the Method for analysis of INDustrial energy systems (MIND). Limitations on the internal energy supply or demand will also increase the importance of flexibility and of being able to buffer, use, or immediately sell any energy surplus. In for example Grunow and Gunther's (2008) model, the capacity of the energy transformation equipment set limitations for the amount of energy related co- or by-products that can be produced, indicating some of the very many complex planning issues around energy.

\subsubsection{Mathematical Modelling in Process Industries}

The literature also provides some examples where mathematical modelling can be useful for process industries. For example, by combining both strategic and operative planning aspects in one mixed integer linear programming model, Kallrath (2002a) show how cost savings can be achieved through for instance reduce urgent transportations. Kallrath (2005) presents later on an overview of process industry planning and design problems, solved through the use of mixed integer optimization. According to Kallrath (2005), supply chain planning problems are commonly solved using mixed integer linear optimization. Paiva and Morabito (2009) also present a mixed integer optimization model, but for aggregated production planning in a sugar and ethanol milling company. Aiming to provide support for decision making, Paiva and Morabito (2009) as such involve the choice of production processes, quantities, inventory levels, suppliers, and transportation in the model. Mathematical modelling can also be useful for different kinds of Decision Support Systems in process industry environments (e.g. Mallya et al., 2001). To integrate decisions for production planning with inventory control decisions, can according to Mallya et al. (2001) make a Decision Support System useful for continuous manufacturing environments, even with widely varying and independent demand patterns. Such approach could for instance help Linus in his cookie factory to decide how large batches he should run and which ones to prioritize. For instance, Bredström et al. (2004) determine daily supply chain decisions, over a planning horizon of three months, in their mixed integer models for a pulp company. However, none of these pay any extra attention on energy issues, despite the energy intensiveness of process industries.

\subsubsection{Integrating Energy Issues in the Planning Processes}

To integrate more energy issues in the planning processes for the energy intensive industry seems promising. For example, an energy-mix problem can according to Arivalagan et al. (1995) be handled by a mixed integer linear programming model. The use of decision support practices for production related investments in the foundry industry, investigated by Thollander et al. (2009), also show that fluctuating electricity prices will affect the choice of investments. In a decision support tool for strategic analysis and tactical planning of forest fuel supply, Gunnarsson et al. (2004) consider the energy content of the forest fuels. However, not that many examples could be found in the literature where energy aspects are included in the supply chain planning or production planning context for process industries. 
Nevertheless, Wolters et al. (1995) presents a modelling method for general industrial production processes. It is divided into three parts; using energy to transform raw materials into desired commodities (transformation), making energy available in the right quantity and quality (utility), and recovering residual heat (heat recovery). If production also consist of batch processes, an additional part; where start and end times of different batches are controlled (control), will be needed. This decomposition is thus applicable on most production processes according to Wolters et al. (1995), who moreover identify boilers and combined heat and power (CHP)-units as most important in the utility part. They also highlight the importance of the transformation part, when minimizing the energy use in production. Other examples show that about $10 \%$ of the energy costs can be saved by optimizing the production plan in a cement industry (e.g. Schmalzried, 1998). More recently, Kalenoja et al. (2011) present a framework for measuring the energy efficiency in a supply chain from a logistic perspective using system boundaries.

When it comes to process industries, it seems to be common to tailor-make your own planning system by combining different tools (Ashayeri et al., 2006; Johansson et al., 2012). An example of this is provided by Mallya et al. (2001) that use Excel and Access in combination with AMPL, although no special concerns are taken to energy aspects. Bakhrankova (2010) present, on the other hand and with more respect to energy, a modelbased Decision Support System, entitled Energy Optimizer (ENEO) that is built on two modules: one for just energy cost minimizations, and another for combined energy cost minimization and output maximization. Decisions in ENEO include the production quantities and resource utilization, while simultaneously synchronizing production and distribution planning. The solution heuristics is built upon three main solution steps: using database access connecting Excel with AMPL (A Mathematical Programming Language), using VBA (Visual Basic for Applications) macros in Microsoft Excel, and a read and write configuration via the Open Database Connectivity standard under Windows. Some similar solutions steps have also been useful while working with the Energy Mission model presented in the second and the third paper of this dissertation. According to Bakhrankova (2010), their approach can help daily production planning with several operational functions, reach energy cost savings and improve both reactivity and capacity utilization. To sum up, there is still room in the literature for additional research that investigates the value of integrating energy issues in the planning processes for process industries. 


\section{Description of case companies}

In this chapter a brief overview of the case companies involved in this dissertation is provided. Some general information about the companies can be found in Table 5.

The case company of the first study, Perstorp, is a specialty chemical process industry. The site visited, which also is the company headquarter, is located in the town Perstorp situated in the southern part of Sweden. The company has in total nine production sites in eight different countries throughout Asia, Europe, and North America. Plenty different products, categorised in about 30 different product groups, are sold on a global market. Its yearly turnover amounts to about 1.6 billion USD and they have about 1500 employees.

The case company investigated in the second study, Södra Cell, is a leading pulp producer with three production sites in the southern part of Sweden. At the time of the study the company initially also had two production sites in Norway, out of which one was included in the study. They produce about 15 different types of pulp that are available on a global market but mostly sold in Europe. Its yearly turnover amounts to about 1.4 billion USD and they have about 1600 employees.

The case company in the third study, SSAB, is a steel producer focusing on high strength steels. SSAB acts on a global market and has production facilities in USA and Sweden. The focused part of this study, SSAB EMEA, has three production sites spread across Sweden and acts on the European and Asian market selling numerous different products categorised in seven different product groups. SSAB EMEA's yearly turnover amounts to about 2.7 billion USD and the company has about six thousand employees. 
Table 5 - General information about the case companies (Source: the company home pages and year end reports for the year 2013).

\begin{tabular}{lccc} 
& Study 1 & Study 2 & Study 3 \\
\hline Case company & Perstorp & Södra Cell & SSAB EMEA \\
Yearly Turnover (M\$SU) & 1590 & 1350 & 2700 \\
\# of employees & 1500 & 1400 & 6000 \\
Annual Energy Use (GWh) & 2100 & 9600 & 2700 \\
\# of factories/sites & 9 & 3 & 3 \\
\# of product groups & 30 & 1 & 7 \\
Main Market & Global & Europe & Europe/Asia
\end{tabular}

Some characteristics regarding the case companies' production can also be found in Table 6 . The data in Table 6 was gathered through several semi structured interviews among personnel holding key positions for production planning and supply chain planning at the companies (for case Perstorp and case Södra Cell; see also Johansson et al., 2012). Whereas SSAB and Södra Cell procure rather few types of raw materials for their production, Perstorp requires a larger variety for theirs. They all have continuous production, although Södra Cell and SSAB divide it into batches grouped in larger campaigns. As such, there is a sequence dependency at changeover between both batches and campaigns. For Perstorp, that for some product types has dedicated production equipment, sequencing is thus not applicable. The bottleneck could vary in production depending on several different conditions, as well as the recipe run at the moment. Perstorp and SSAB have the most diverging flow with many different product types on the output side. When it comes to planning support, Excel is frequently used in practice although other support is available. In such context, case Perstorp uses an Enterprise Resource Planning (ERP) system, whereas case SSAB is in the process of changing from an IBM Database 2 system to an ERP system. The case company Södra Cell use a combination of linear programming (LP) and Excel, and their planning model is more investigated in Paper 2 and Paper 3. The long term planning horizon is about one half to a year, whereas the tactical planning horizon is more different among the companies.

Table 6 - Some production characteristics of the case companies (* normalized comparison among the companies).

Study 1

Study 2

Study 3

\begin{tabular}{lccc}
\hline Case company (Site) & Perstorp (Perstorp) & Södra Cell (all) & SSAB EMEA (Borlänge) \\
\hline $\begin{array}{l}\text { Different types of raw materials } \\
\text { procured * }\end{array}$ & Many & Few & Few \\
\hline Production mode & Continuous & Batch/Continuous & Batch/Continuous \\
\hline $\begin{array}{l}\text { Sequence dependent } \\
\text { changeover }\end{array}$ & No (or N/A) & Yes & Yes \\
\hline Bottle neck in production & Varying & Varying & Varying \\
\hline Number of product types * & Many & Few & Many \\
\hline Planning support & Excel/ERP & LP/Excel & DB2 -> ERP \\
\hline Long term planning horizon & 6 months & 1 year & 1 year (3-6 months) \\
\hline Medium term planning horizon & 3 days & 3 months & 2 weeks
\end{tabular}


The planning processes for the case companies involved shown in Figure 8 for Case Perstorp, Figure 9 for Case Södra Cell, and Figure 10 for Case SSAB EMEA Borlänge, are in many ways quite similar to each other. For instance, they all let the organisational part responsible for the supply chain act as the central part of the planning process matching capacity with demand. One case company, Södra Cell, however also include procurement in their planning process. This is due to the structure of their ownership, since a very large proportion of their raw materials is procured from the owners.

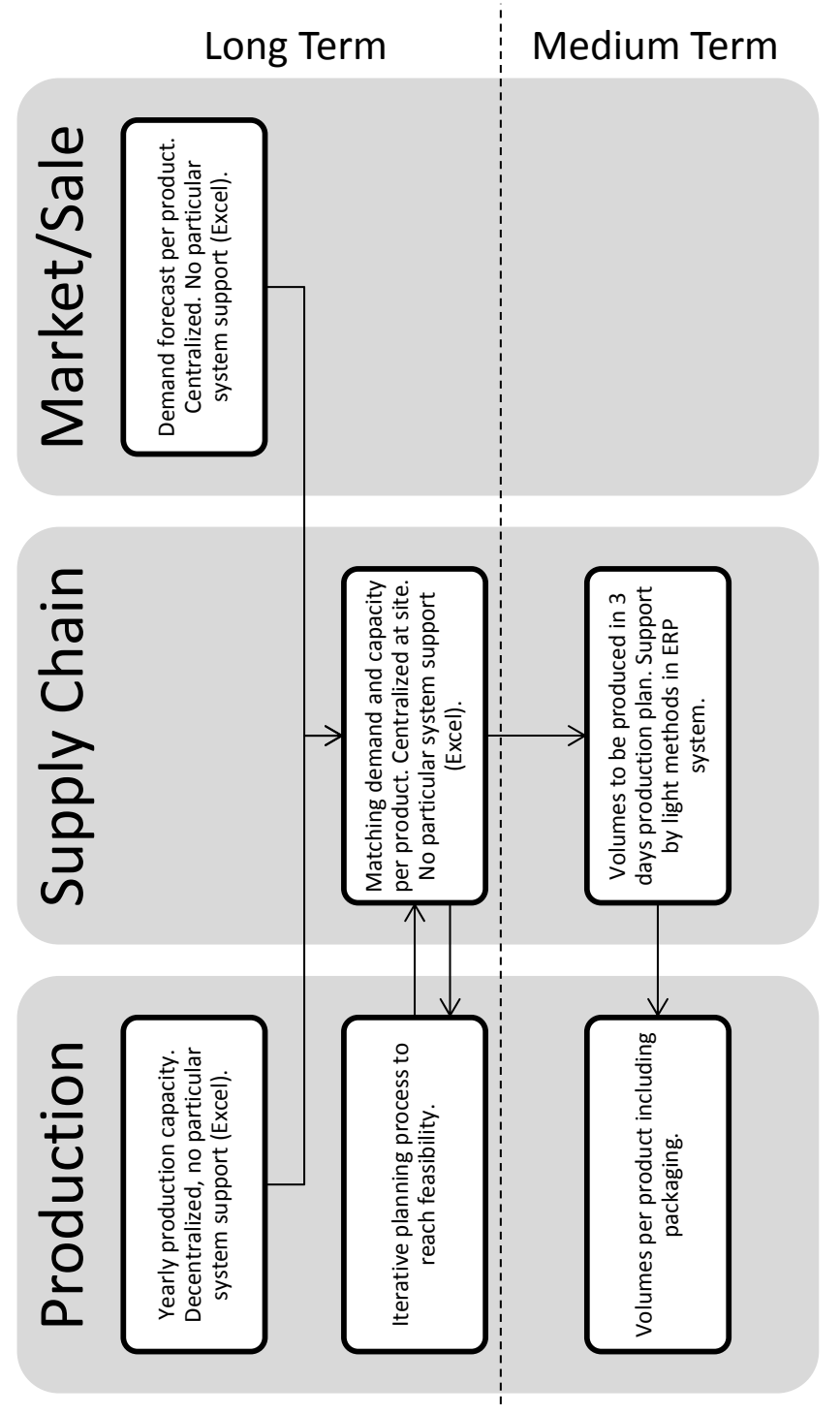

Figure 8 - The Planning Process for Perstorp (Johansson et al., 2012). 


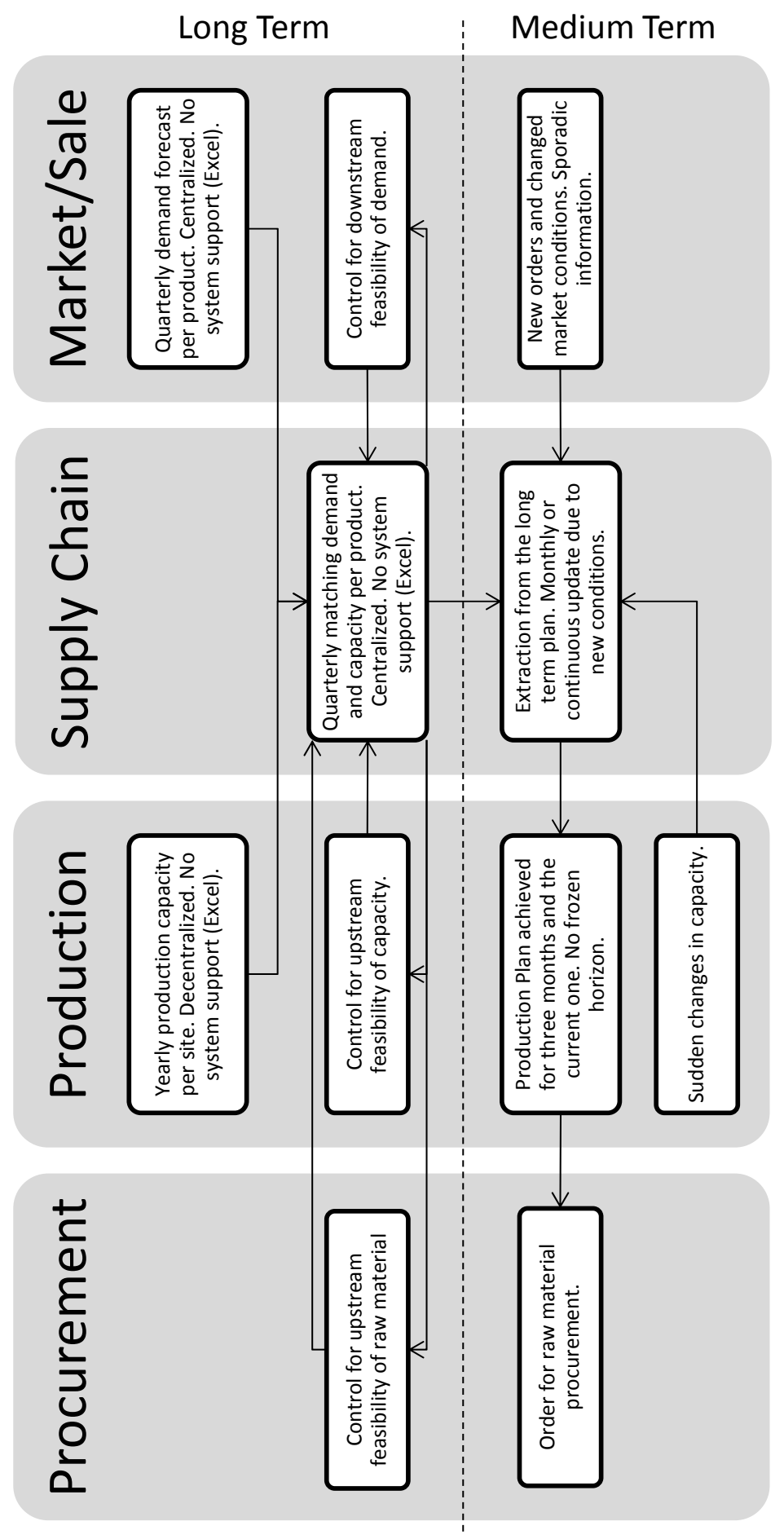

Figure 9 - The Planning Process for Södra Cell (Johansson et al., 2012). 


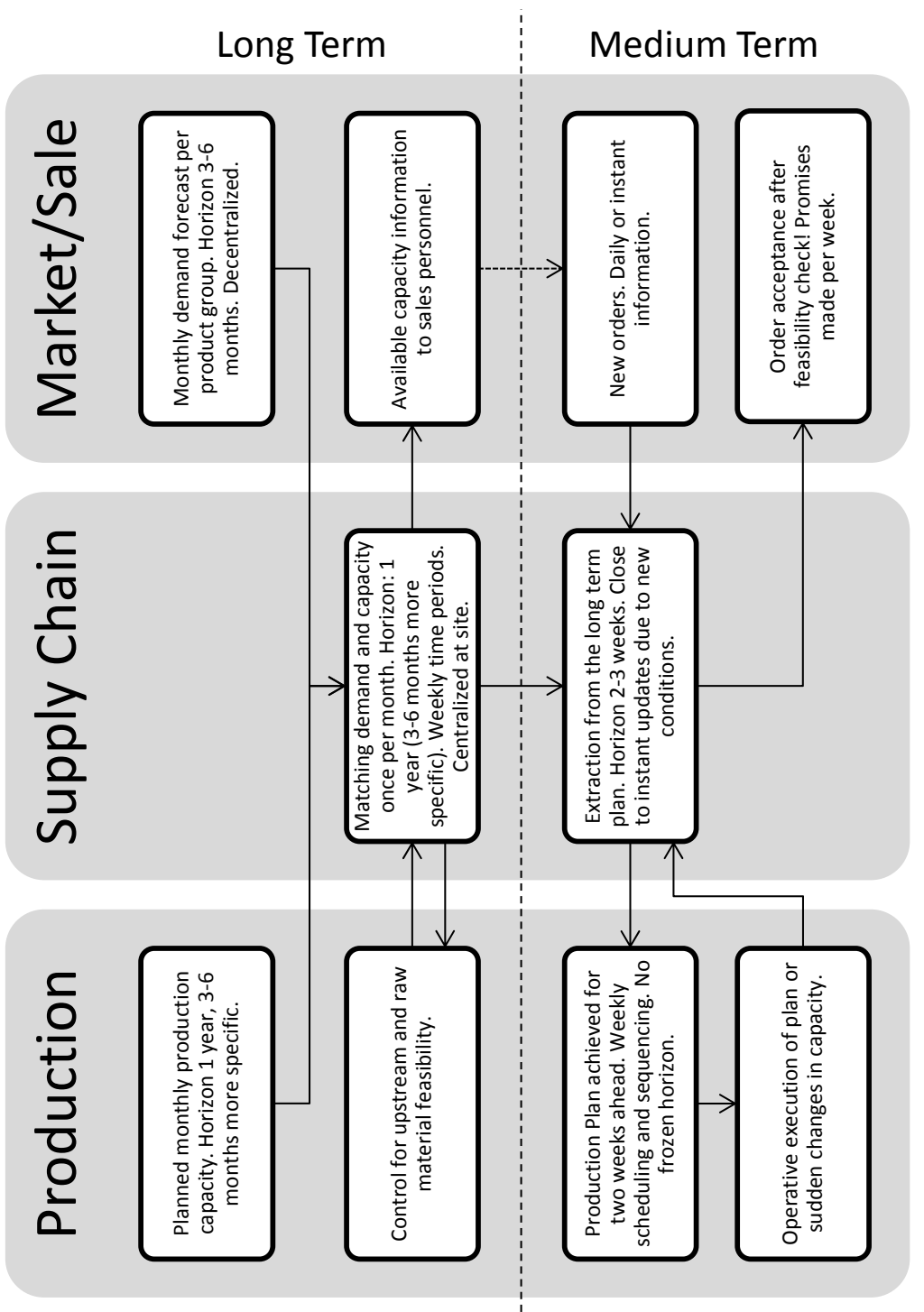

Figure 10 - The Planning Process for SSAB, EMEA, site Borlänge. 


\section{Summary of the Papers}

The papers attached to this dissertation are summarized in this chapter with their purposes, research questions, general content, contribution, and overall conclusions. However, to begin with, an overview of the most referred literature used in these papers, which is also referred to in this introductory part of the dissertation, can be seen in Table 7. In addition, an overview of the selected keywords for each paper can be seen in Table 8.

Table 7 - Some of the most common literature in this dissertation.

\begin{tabular}{|c|c|c|c|c|c|}
\hline Reference \Paper & Paper 1 & Paper 2 & Paper 3 & Paper 4 & Paper 5 \\
\hline APICS Dictionary $(2008 ; 2002)$ & $x$ & & & $x$ & $\bar{x}$ \\
\hline Finch and Cox (1987) & $x$ & & & $x$ & \\
\hline Fransoo and Rutten (1994) & & & & $x$ & $x$ \\
\hline Gunnarsson and Rönnqvist (2008) & & $x$ & $x$ & & \\
\hline Gunnarsson et al. (2007) & & $\mathrm{x}$ & $x$ & & \\
\hline Hayes and Wheelwright (1979a) & & & & $x$ & $x$ \\
\hline Kalenoja et al. (2011) & $x$ & & $x$ & $x$ & \\
\hline Klugman et al. (2007) & $x$ & $x$ & & & \\
\hline Marshman et al. (2010) & $x$ & $x$ & $x$ & & \\
\hline Thollander and Ottosson (2010) & $x$ & & & $x$ & $x$ \\
\hline Thollander et al. (2009) & & & & $x$ & $\mathrm{x}$ \\
\hline Wolters et al. (1995) & $x$ & & $x$ & & \\
\hline Yin (2009) & $x$ & & & $x$ & $x$ \\
\hline Özdamar and Birbil (1999) & $x$ & $x$ & $x$ & $x$ & $x$ \\
\hline
\end{tabular}


Table 8 - Selected Keywords for each Paper.

\begin{tabular}{|c|c|c|c|c|c|}
\hline Keyword \Paper & Paper 1 & Paper 2 & Paper 3 & Paper 4 & Paper 5 \\
\hline Case study & $\mathrm{x}$ & & & $x$ & $x$ \\
\hline Energy / Energy system & & & & $x$ & $x$ \\
\hline Energy efficiency & $\mathrm{x}$ & & & $x$ & \\
\hline Energy management / Energy revenues & $x$ & & $x$ & & \\
\hline Energy planning & $\mathrm{x}$ & $\mathrm{x}$ & & & \\
\hline Energy-intensive production systems & $x$ & $x$ & $x$ & & \\
\hline MILP model & & $\mathrm{x}$ & $\mathrm{x}$ & & \\
\hline Process industry & & $x$ & $x$ & & $x$ \\
\hline Production planning & & & & $\mathrm{x}$ & $x$ \\
\hline Specialty chemicals & $x$ & & & & \\
\hline Steel / Steel industry & & & & $\mathrm{x}$ & $x$ \\
\hline Supply chain optimization / SC planning & & $x$ & $x$ & $x$ & \\
\hline
\end{tabular}

\subsection{Summary Paper 1}

This paper entitled "Strategic Perspectives on Energy Management: A Case Study in the Process Industry", has the purpose to "investigate the necessary prerequisites for putting energy management" on the strategic agenda in energy-intensive process industries. Three case study questions are raised:

CQ 1. What issues are important to consider for establishing a strategic perspective on a company's energy system?

CQ 2. What issues are important to consider for getting strategic attention on the utilization of a company's energy system?

$C Q$ 3. What issues are important to consider for getting strategic attention on investigating the possibilities for finding alternative revenues from a company's energy system?

The case is analysed from three perspectives; a strategic perspective, an energy system utilization perspective, and an alternative revenue perspective. The central issue is though how energy management is treated from these three perspectives. Findings show that most energy-intensive companies do not regard energy as "core" to their business, and that they lack a strategic perspective on energy management. For instance, even though there are managerial means available for increasing the energy efficiency, they are seldom put into practice. The paper also discusses possibilities to increase revenues by selling energy related by-products, and gives some practical examples of good and poor energy management. The importance of organisational cooperation and assigning someone responsible for corporate energy issues is also put on the table, as well as the effect of political continuity on strategic energy related decision making. Moreover, for a typical company in the process industry sector, this paper indicates necessary prerequisites, for each perspective, for putting energy management issues on the strategic agenda. To conclude, this paper argues why energy issues should be considered as strategic issues in energy intensive process industries. 


\subsection{Summary Paper 2}

This paper entitled "Including energy in supply chain planning at a pulp company" has the purpose to "develop a model for integrated supply chain and energy planning for a multi-site pulp company, treating energy not only as an input to the pulp process, but also as a saleable output from the production process". The aim is therefore to investigate the effects on profitability while taking energy issues into consideration. Beside material flows, also energy flows are thus considered for revenue generating purposes. The paper is based on a case study and the MILP model; Energy Mission is developed for the entire supply chain. Decisions included in the planning are; purchase and transportation of raw materials from harvest areas to pulp mills, production allocation by dividing the production among the pulp mills, energy mix by choosing the energy input at the pulp mills, and distribution of products from mills to customer. The model is analysed through a number of different scenarios including real data from the case company. The evaluation shows that there is a clear potential economic impact of involving energy issues into a supply chain model for this pulp company. The paper thus contributes with showing that such planning perspective is theoretically possible to implement and that it can make a difference if applied.

\subsection{Summary Paper 3}

This paper entitled "How energy price changes can affect supply chain planning at a pulp company" has the purpose to "deeply analyse the impact of energy price changes on supply chain and production planning at a pulp company". By using a refined version of the Energy Mission model presented in Paper 2, the paper aims to reveal how changed energy prices of different kinds are handled by the model and what changes in supply chain and production planning it consequently suggests. It also aims to find out if some products and/or pulp mills are preferable, and more compatible in the overall energy effectiveness of the company, in times of changed energy prices. As such the paper analyses how energy issues can suggest the plan to change by for instance changing the production mix, the production volumes, and the electricity output. This is done through sensitivity analyses of energy price changes in the supply chain optimization model. Findings show that there is room for different planning approaches to maximize the total profit, since for instance differences in energy effectiveness can shift production allocation between different sites. Triggered by a price change of energy, the Energy Mission model also prioritizes in its selection of pulp products to produce, and where and when to increase or decrease pulp production. As such the paper argues that the product price should reflect the embedded energy and accumulated resource intensity more fairly. The paper thus confirms that alternative revenue from energy-intense raw materials is prosperous enough to be included in the planning processes of production and supply chain. It also contributes with strengthening the usefulness of the developed model and point out some of its advantages. 


\subsection{Summary Paper 4}

This paper entitled "Energy issues in supply chain and production planning in the steel industry - A case study at SSAB" has the purpose to "investigate how the production processes interact with the energy system and how improvements can be done by planning the operations differently". Three case study questions are raised:

CQ 1. What potential improvement areas can be found where production costs can be reduced and energy can be saved?

CQ 2. How can overall energy efficiency within each improvement area be increased without negative impact on production?

$C Q$ 3. What barriers and drivers can be located for each improvement area?

The case study is urging to merge energy management processes with operations management processes by investigating the energy system and production process intersections. As such it maps the production processes and its supporting energy system at a steel company's production site, in order to locate the largest and most important intersections. Striving to increase overall energy efficiency without disturbing production, these intersections are later analysed with respect to their potential in terms of both monetary savings and energy savings. The paper is thus an example of case analysis considering intersections between two different research domains: energy management and production planning. Findings reveal four important improvement areas where energy and production costs can be saved: 1) planning slab furnaces, 2) utilising embedded heat and shortening lead times, 3) broader frame when scheduling for decreasing waste at set-ups, and 4) demand-response opportunities related to electricity price variations. Barriers and drivers for the improvement areas found are analysed, and the paper concludes that the energy system and the production processes can be utilized combined in a more efficient and effective way.

\subsection{Summary Paper 5}

This paper entitled "Energy considerations in planning slab furnaces at a steel company - A case study at SSAB" has the purpose to "investigate how planning of the slab furnaces could be done in order to decrease production costs". Three case study questions are raised:

CQ 1. How do energy related costs impact the slab furnace planning problem?

CQ 2. To what extent could planning of the slab furnaces be done differently in order to lower the costs for production?

The case study is thus deeply analysing the first improvement area found in Paper 4. This part of the energy system, the production processes, and their intersections has large flows of both steel and energy that exchange value. The planning problem is analysed with two analytical models distinguishing the differences between the two parallel slab furnaces. These models are based on principles for economics of scale and lot sizing through economic order quantity. As such the models evaluate both fixed and interchangeable cost (volume dependent) and the paper analyses how the models suggest different slab furnace utilization 
strategies, depending on the current demand, and different fuel prices for each slab furnace. The paper contributes by showing how increased energy efficiency can be achieved by implementing an energy-related approach in planning and scheduling of the slab furnaces and the hot rolling processes. To conclude, by choosing a primary and secondary slab furnace based on their energy characteristics, a different planning approach is suggested based on energy efficiency and economic considerations. 


\section{Reflective Summary and Contribution}

What is worth something and what is worthless in our daily life is often based on subjective judgements of our minds. Warren Buffet once said that price is what you pay and value is what you get. That might explain why some prefer to pay extra for abstract values without a direct link to specific costs along the value chain. Whereas supply and demand set the boundaries of the market, our minds set the price on the value. It therefore seems like things that we cannot get enough of, we value more. Hence, if we cannot get enough of useful energy, we should value it more. However, industrial energy flows are mostly viewed upon from the cost side, despite profitable revenue possibilities. In an energy system, it exists different kinds of useful energy depending on its exergy content (or quality), whereas different kinds of production processes need energy input with different levels of exergy. The real value of the embedded energy provided to a product along its value chain is thus related to how perfect match it is between an energy demanding production process and its supplying energy system. But it does not end there. Since energy cannot be consumed or destroyed and only transformed into another form, there will always be another energy stream, with lower exergy content, on the other side of the production process after its primary use of energy. The more intersections between the production processes and the energy system there is, the more complex the situation becomes, but the number of opportunities to use the right type of energy at the right place does also increase. Therefore, the energy efficiency and effectiveness of a production process, a company, or even the entire region, depends on how well these intersections match. For the production processes it also depends on how production is planned to proceed. Therefore, production planning, that also relates to supply chain planning, has a direct impact on energy efficiency and effectiveness. Logically, when the value of the energy commodities involved is large enough such impact should be mutual, with an increased prioritization in the planning process of production and supply chain. This dissertation argues that such mutual relationships exist and should be considered important enough in making various decisions at energy intensive process industries. 


\subsection{Answering Research Question 1}

How do current energy management practices in process industries relate to the task of ensuring profitability both today as well as beyond tomorrow?

The answer to this question is rather wide and can be found in many parts of this dissertation. However, the content in utmost Paper 1, but also paper 4 and Paper 5, brings plenty of insights for answering this question. To begin with, there is a literature review on energy management in process industries that can be found in Paper 1. Overall, there is a lack of strategic attention on energy issues in many levels of the case companies investigated in this dissertation. In the first study presented in Paper 1, the case company has a rather poor organisational integration of energy issues, where decisions are made decentralized and follow no formal planning approach. The lack of involvement is also detected regarding supply chain and production planning at the case company investigated in the second study presented in Paper 2 and Paper 3. Similar results are also found at the case company in the third study presented in Paper 4 and Paper 5 where complex production processes, with for instance a problematic sequencing, often puts energy issues into a lower prioritization or does not consider them at all in the production planning process. The lack of organisational integration and general lack of involvement in energy management practices found are all in line with previous findings by Christoffersen et al. (2006). However, whereas studies as Christoffersen et al. (2006) focuses more on to what extent energy management is practiced, the research in this dissertation focuses more on the corporate requirements on energy management practices. For instance, the necessary prerequisites for putting energy management on the strategic agenda are investigated in Paper 1. Nevertheless, the research question also relates to how process industries, with their most likely flow oriented production, typically are managed, where the choice of flexibility, product diversity, and equipment dedication, as well as responsiveness to rush orders with respect to scheduling sequences, belong to the most important decisions (Taylor et al., 1981a). However, literature also enlightens the importance of long range energy plans (Taylor et al., 1981a), energy mix and optimal utilization of energy resources (Arivalagan et al., 1995), and argues that supply chain decisions can have significant impact on the use of energy (Kalenoja et al., 2011). The energy management issue is moreover analysed below, as in Paper 1, from three different perspectives: strategic, efficient utilization, and alternative revenue.

Related to the strategic perspective, Paper 1 concludes that energy issues are seldom treated as "core" to the business even though the company is expected to benefit on giving it more attention. The paper thus show how a company can go strategic with energy management practices, such as working with energy efficiency and effectiveness, no matter if it should do that or not from a corporate strategy point of view. Corporate strategy as such, should hence not be too narrow in its focus (Skinner, 1969), and probably not too narrow regarding the energy strategy either. This also applies to the decision-making on energy-efficiency investments, where the importance of the strategic dimension cannot be 
neglected (Cooremans, 2011; 2012). As for the dissertation in general regarding this context, the approach is more of how to make companies aware of their potential map of corebusiness, rather than looking at structural effects in order to analyse change of core business. Core-business as well as corporate strategy is hence for management, and not for research, to decide. Research can nevertheless highlight how the connection between energy-efficiency investments and the company's competitive advantages impact the core business of the company, as called for by Cooremans (2012). In such context one could question if it is easier for management to see energy revenues as core for business than energy cost cuttings, calling for further investigation. The literature also enlightens the importance of a wider corporate involvement regarding strategic energy decisions (e.g. Bengtsson et al., 2002; Tari and Söderström, 2002; Karlsson, 2011; Cooremans, 2011), and that the strategic dimensions of energy issues also are a matter of long term competitiveness (e.g. Lovins, 1976; Carlsson et al., 2009). Therefore it is very surprising to find such lack of strategic attention as for the case in Paper 1, although it partly, to the case company's defence, can be explained by their view on energy issues as a high risks domain due to a perceived lack of political continuity.

The utilisation perspective in Paper 1 discusses how the energy commodities are utilised, for example that oil is chosen for flexibility reasons despite being more expensive than bio fuels that are more complex in its utilisation. This issue is also discussed regarding demand response opportunities in Paper 4 that, due to uncertainties and limitations in the electricity supply chain, has not been put into practice. The utilisation perspective is also discussed in Paper 5 where the problem relates to how the two slab furnaces, heated by different fuels, should be utilised and managed in case special production requirements out of the ordinary occur. In that case, the company actually stands relatively prepared since there are considerable costs involved with heating the slab furnaces. However, the equipment has a slow momentum leading to stepwise actions when changes occur. The economic dimension attached to the energy utilisation perspective is also discussed in Paper 4 stating that the energy market is volatile, providing plenty of opportunities for improving the planning, yet not considered important enough by the company due to risk issues and logistic limitations. Despite the fact that process industries experience energy costs around $10-20 \%$ of the total costs (Thollander and Ottosson, 2010) and that they top the list of energy usage per product value (Stratton, 1979), there are still other issues that are considered as more important among several process industries. The most preferable energy savings are as such often considered to be represented by the products that fulfil the quality requirements, and therefore do not waste any added value or energy, as stated in Paper 5.

The alternative revenue perspective in Paper 1 states that the revenue possibilities from byproducts are high and that their pricing sometimes does not reach the value of their energy content. However, whereas increased revenues from excess heat are limited by the district heating market for the case in Paper 1, the case company in Paper 4 experiences no such limitations, yet. Further possibilities to increase the revenue are however often related to 
large investments, that as argued in Paper 1 most likely compete with other investment alternatives within the company. Accordingly, new investment alternatives must thus deliver a competitive internal rate of return high enough to satisfy the decision makers, which is also in line with the statements of Cooremans (2012) when it comes to energy efficiency investments. Even though improvements with an exergetic potential most certainly can be found since the industrial energy efficiency gap reaches $80 \%$ from a thermodynamic point of view, and $50 \%$ considering what is technically possible according to Hammond (2007), it is still the economic considerations of their implementation that counts. A relative increase of energy prices should thus make companies more inclined towards investments in energy efficiency and effectiveness. However, managerial energy improvements are sometimes more likely to be triggered by governmental initiatives, as discussed in Paper 1 , where a decreased energy usage is promoted by tax reductions. It is thus rather surprising that energy intensive process industries need other initiatives, than what their own business strategy provides, to beware of energy issues that according to Thollander et al. (2009) could be very crucial for their long term survival.

\subsection{Answering Research Question 2}

How can process industries include energy related issues in their planning processes of production and supply chain?

Since planning processes in process industries often are tailor made (Ashayeri et al., 2006) and individual for each company with their own specific production processes, and since no applicable and to the best of our knowledge also generalized and standard approach could be found in the literature, no general approach has been selected to serve as a standard model and basic approach. The examples presented in this dissertation on how energy issues can be included in the planning processes for process industries are thus based on individual and rather case-unique situations. However, this does not prevent other companies to develop their own similar approach, inspired by the suggestions provided in this dissertation. In Paper 2, the Energy Mission model is developed showing how steam, electricity and other energy intensive by-products can be included in the recipe structure of a supply chain and production planning model for the pulp company investigated. It is a mixed integer linear programming model using real company data. Energy Mission is later refined in Paper 3 in order to through a sensitivity analysis state its impact and usefulness. This also illustrates the importance of side-flows that instead of being viewed upon as by-products should be considered as somewhat necessary co-products. The production and the supply chain of the case company Södra Cell, has previously been studied numerous times (e.g. Carlsson and Rönnqvist, 2005; Gunnarsson et al., 2006; Gunnarsson et al., 2007; Gunnarsson and Rönnqvist, 2008; Lidestam and Rönnqvist, 2011), but none of these studies have taken the energy issues into special consideration as done with Energy Mission in Paper 2 and Paper 3. Plenty of modelling opportunities, where the energy system interacts with the production processes in many different ways, have also been found for the case company involved in the third study presented in Paper 4 and Paper 5. This led to the development of the model 
presented in Paper 5, exemplifying how the use of two parallel slab furnaces for the heating of slabs before the hot rolling can be problematized, formulated, simulated, and compared. The model use real company data and are based on two different approaches: on the one hand economics of scale, and on the other hand lot sizing advantages from an economic cycle time point of view. The model are not as advanced or as broad as the Energy Mission model but is still proven to be useful for computing the possibilities of what a different planning perspective can provide.

There are some models in the literature that consider supply chain planning in process industry environments (e.g. Kallrath, 2005; Paiva and Morabito, 2009; Gunnarsson et al., 2004; Bredström et al., 2004) but very few could be found where also energy issues are involved (e.g. Wolters et al., 1995; Schmalzried, 1998; Kalenoja et al., 2011). This dissertation thus contributes with a few additional examples on how this type of problem can be conceptualized, modelled, and to some extent also solved and validated. Since the models also are based on a real problem situation, the contributions also span over a considerable part of the framework for quantitative research presented by Mitroff et al. (1974). As such, the real problem situation in Paper 2 and Paper 3 locates possibilities to plan differently due to the characteristics of the raw materials and their impact through different recipes. The problem situation in Paper 5 moreover locates possibilities to plan differently more based on differences within process equipment and its response to various degrees of utilisation. The planning horizon is also different: one year with monthly time periods is used in Energy Mission in Paper 2 and Paper 3, whereas one period of a few weeks is used in the models in Paper 5. The common goal is however to find a better planning solution than what current practices provide, and in the given situations it is proved that the impact of different energy prices plays a significant role in all developed models. In order to reveal such impact, the most promising energy related issues, such as demand and supply of different forms of energy, as well as the energy prices, as also highlighted by Stratton (1979), have been involved in the planning contexts. As such, additional value and revenues from an energy surplus, as well as from co- and/or by-products that can be sold or utilised elsewhere, have been located and as far as possible included in the models. In the Energy Mission model this is done with including energy input and output in the recipe structure but also to include energy system equipment such as combined heat and power in the model. And with similar attempt, Paper 4 strives to focus on the most impacting energy issues for the real problems related to each and one of the improvement areas located. As such, the planning situation for the slab furnaces, utilising embedded heat and simultaneously decrease lead-times, decreasing waste at set-ups through a wider scheduling approach, and utilising electricity price variations through demand response, all represent areas where energy issues could be included in a production and/or supply chain planning context. Whether energy issues then should be included in such planning context or not, is for decision makers and managers to decide. Such decisions are preferably based on economic evaluations or similar such as the one presented in Paper 5. By analysing the first improvement area from Paper 4, Paper 5 thus investigates how a different production plan is affected by different price levels of the 
different fuels for the slab furnaces. Another economic evaluation is found in Paper 3 where the expected impact of the Energy Mission model is analysed.

Nevertheless, energy issues have also been proven to be relevant by managerial means in utmost the energy intensive process industry, as argued previously about the first research question. In Paper 1, a more centralised approach to integrate energy issues in the planning context is thus proposed in order to avoid sub-optimized solutions, but also to open up for corporate-wide energy savings through establishing a corporate energy manager with the main responsibility of such issues. Since important energy efficiency decisions are made in production planning and product design (Kalenoja et al., 2011), it is thus logical to include the most relevant energy issues in such context. As such, Energy Mission considers decisions on procurements, production allocation, energy mix and distribution. The results from the scenarios in Paper 3, analysing market changes for energy demand and price, give therefore an idea on how such model can be used for managerial implications and guidelines. This is in some sense similar to the model and decision support tool provided by Grunow and Günther (2008), but different in how the amount of by-products is produced in their model since it is constrained by the capacity of the energy transformation equipment. In Energy Mission we instead use two kinds of by-products, or co-products are perhaps a more rightful name considering their importance: energy products and energy carriers. The energy products in the form of bark, black liquor, methanol, liquid rosin and turpentine are constrained by the raw materials used and the capacity of the production process. The energy products can then be used in energy transformations to produce energy carriers such as electricity and steam constrained by both the availability of energy products and by the capacity of the energy transformation equipment. Capacity, that commonly lags in process industries (Olhager et al., 2001), is moreover a central managerial issue for planning and scheduling, and is also discussed as a barrier for energy improvements in Paper 4, and is one of the key problems in Paper 5 when deciding which slab furnace to utilize the most if reaching for higher energy efficiency. Hence, the opportunities to involve energy issues in production and supply chain planning processes at process industries are also somewhat limited by the already existing and typical problems in process industry supply chains. It is thus of extraordinary importance to locate such relations and deal with them in new and innovative ways, as strived for in this dissertation.

\subsection{Answering Research Question 3}

How can the merging of energy issues into the planning processes for production and supply chain impact the profitability of the process industry?

There are several beneficial consequences expected with implementing some of the ideas and models suggested in this dissertation. However, the real consequences of including energy issues into production and supply chain planning cannot be concluded in this dissertation since the implementation phase in Mitroff et al.'s (1974) framework is yet left ahead, and there are thus no confirming studies on real-life situations of using the models 
and managerial implications suggested. Hence, in line with an emergent need for accurate cost-benefit analyses based on reliable data (also enlightened by Tang and Tomlin, 2008), this dissertation takes another step in that direction, in particular with Paper 3 and Paper 5. Whereas optimization is getting more and more important for both planning and design of process industry supply chains (Shah, 2005), we show through scenario simulations in Paper 2 that energy also has a substantial impact in such context. As such, the Energy Mission model provides a different plan than what current practice suggests, making a clear impact on the expected total profit. The analysis of the refined Energy Mission model in Paper 3 clarifies the possible profit increase and reveals which products to prefer due to energy effectiveness issues. Such prioritization gives guidance on where and when to increase or decrease pulp production, which product to produce, and how production can shift between different facilities, due to the involved energy characteristics. In Paper 5 another type of prioritization is argued, where calculations show that savings can be achieved if the slab furnaces are planned differently also compared to current practice. Depending on different price levels on the fuels for the slab furnaces, the efficiency of each slab furnace, and different demand levels on steel, the most cost-efficient slab furnace can be prioritised to be utilized the most, in line with what the model suggests. In both studies there are however substantial energy cost savings that could be reached if the energy issues are dealt with already in the planning stage.

How the energy system affects the supply chain planning could also be included in other decision making processes, and serve as a decision support tool, in for instance investment evaluations. In Paper 1 and Paper 4 we also argue that investment decision very much relates to the awareness of energy issues and the underlying potentials that exist regarding the various alternatives available. To prove impact and importance for strategic, tactical, and operational decisions as aimed by Grunow and Günther (2008), and to show considerable cost savings as intended by Schmalzried (1998) and Bakhrankova (2010), is thus imperative in order to get attention within decision making. The research done in this dissertation is therefore somewhat set in such direction and aimed to be useful for industrial applications. For instance, electricity is argued to already at current price levels be important enough to be included as in the Energy Mission model. To further pinpoint the effects of seasonal variations, and the possible revenues that could be achieved, provides additional arguments for a different planning approach. Additional advantages with the Energy Mission model are pointed out in Paper 3 to strengthen its usefulness. A similar approach is also used in Paper 5 where slim or none investment in additional equipment is needed in order to achieve improvements. The idea is thus to show that large economic benefits can be achieved by small investments in planning processes and its management. That should hopefully attract decision makers' attention.

Other effects of merging energy issues into the planning context can be related to waste minimization opportunities and the avoidance of sub-optimization, as discussed in Paper 1. In Paper 3 we can also see that green certificates on electricity inspire electricity production, 
although it also may increase the proportion of internal electricity utilisation. Despite the extra electricity used for production, increasing the electricity use per ton pulp produced, the supply of green electricity to the market increase. There is also a trade-off between revenues on energy products and energy carriers, depending on the pricing of each energy commodity. These and a lot of other issues exemplify the complexity of balancing environmental and economic concerns. Another complex issue to deal with is when the results from two different models suggest different solutions, as in Paper 5 . However, despite these different suggestions, Paper 5 still contributes with a model used for calculations concluding that it is prosperous enough to prioritize and select one primary slab furnace for most utilization instead of practicing an equal utilization level as done today.

\subsection{Purpose Reflection}

Previously it has been stated that the purpose of this dissertation is to

identify important energy management aspects related to production planning and supply chain planning in process industries, and investigate if a coordinated planning approach, considering these areas, is possible and could be profitable.

Considering important energy management issues, the discussion has been very wide from time to time. However, since the research focuses on process industries, and since process industries in general are rather energy intensive (Thollander and Ottosson, 2010), the selection of the most important managerial energy issues has been rather easy. At least, compared to how it could have been in other types of companies, where the total energy utilisation might be large due to the company size, as for example Apple with about 125 times the yearly turnover of the case company of the second study but only about twice the size of its energy use. In companies like Apple, the energy use has a vast spread and appears almost everywhere in small proportions, thus assumed to be harder to judge in terms of importance. In comparison, the largest energy streams are easier to find in the energy intensive process industries, but might necessarily not be easier to manage, due to the characteristics of the process equipment. In addition, the energy systems in process industries are also more complex since energy use in one process will result in energy flows with a lower quality, or exergy, but perhaps with a high quality enough to provide the opportunity of being useful elsewhere. Such opportunities are more difficult to find if the energy flows are smaller and distributed everywhere. Nevertheless, the selection of the most important energy issues has been chosen from mostly a managerial point of view in Paper 1 and Paper 4, and more from an energy system point of view in Paper 2, Paper 3, and Paper 5.

When it comes to production and supply chain planning, focus has been on the current practice. Since literature states that most process industries are unique and develop their own planning approach (Ashayeri et al., 2006), each case study has mapped how planning is done in each situation. What could be found among the case companies involved is that their planning processes have some similarities (Johansson et al. 2012) but are still different 
enough to be considered case-unique in this context, as mentioned in Chapter 4. Although the sample size, in terms of number of cases in this dissertation, might be too small for generalizing conclusions regarding such matter, these findings yet confirm the existing literature. The observations made and the investigations done on the relationship between the current planning practice and the energy management involvement in the analysed planning perspectives, are nevertheless conclusive among the studies made.

This dissertation also investigates if a coordinated and somewhat symbiotic planning approach, merging energy system and production processes, is possible and could be profitable. With the models developed in Paper 2, Paper 3, and Paper 5, it has been shown that it is possible, although the implementation phase is still left ahead, and also most expected to be prosperous for the company. That is, that both profitability and energy savings can be achieved with only managerial implications, with no expected requirements on large investments. This somewhat summarizes what practical implications that may come from this research, and also what benefits companies can achieve if applying this research. 


\section{Concluding Discussion and future research ideas}

Our dependency of process industries is indeed large. Process industries involve a lot of resources, and are capital intensive, making planning imperative for their utilization. They all together stand for almost one fifth of the global use of energy, and their energy costs can sometime reach half of their operative costs. Process industries are hence a large sector with possibly vast environmental impact. This is some of the fundamental reasons why researching on energy intensive process industries is imperative for the evolution of our society. Questions how process industries use energy for production and how this relates to the planning procedures of their activities and processes is a part of such research. Therefore this dissertation investigates how process industries can save both costs for both production and energy usage simultaneously, by planning and managing its activities and processes differently. It is pointed out that an extra attention on energy management aspects, within planning of process industry production and its supply chains, can open the door for increased revenue possibilities, energy savings, and profitability for the company.

\subsection{Applicability in general}

The achievements strived for in this dissertation can be summarised into a combination of increasing profit or decreasing costs whilst saving as much energy as possible, and to test if such problems can be formulated and solved in a comprehensible way. To increase profit as much as possible, a company should manage all its activities and processes, in a way that gives all the benefits to the sum of practice, in other words the result on the final line. The reason why sub-optimisations occur is often due to the vast complexity of modelling all activities and processes simultaneously. To make the situation comprehendible, the task is therefore divided into several smaller models, each with their own objectives and goals and based on their own related systems and processes involved. However, sometimes the intersection between different systems and processes, such as production processes and the 
energy system, becomes important enough to consider as a puzzle piece of its own in the larger picture. That, and to show that there are win-win situations where both energy can be saved and profits increased, is somewhat what this dissertation aims to enlighten.

The purpose of this dissertation points out one direction for research in the energy intensive process industry segment. A general approach and set of guidelines on how to identify important energy management aspects related to production planning and supply chain planning, and how to investigate if a coordinated planning approach, considering these areas, is possible and could be profitable for the energy intensive industry in general is suggested below:

A. Map current energy management practices and analyse how they relates to

1. a strategic perspective on energy including drivers and barriers,

2. an energy system utilization perspective with respect to energy efficiency and effectiveness,

3. and an alternative revenue perspective on possibilities with by-products and co-products.

B. Map the major flows of energy and products in the supply chain and the production processes.

1. Locate where the largest intersections of value exchanging activities occur.

2. Analyse how the flows intersect and set up rules for the value exchange (e.g. recipes).

3. Check for data availability.

C. Map the company planning processes

1. Analyse relevant planning parameters such as e.g. volumes, products, product groups, setups, capacity constraints, planning period, and planning horizon.

2. Analyse software and system support (in use today or preferred tomorrow) and choose relevant software to adopt with regards to usefulness and applicability.

D. Conceptualize and build a model in relation to previously found conditions.

1. Build a functional preliminary model, run the model and analyse the preliminary results.

2. Validate the preliminary results with corporate staff, refine the model until valid.

3. Optimize, generate result, and/or suggest a feasible solution.

E. Analyse the impact of increased attention on energy aspects

1. Analyse and compare the results to current practices, by for example using a "before and after" approach, in order to reveal potential benefits.

2. Analyse what motivators and drivers that balance contradictions and barriers.

F. Implement and adopt suggested approach in the company.

G. Follow up, and continuously refine the applied approach by redoing parts of previous steps. 
A proper selection of these guidelines and parts of the suggested approach, with regards to the characteristics of the task to solve in each case, is nevertheless advised. When taking on a new problem for research in a similar direction as pointed out by the purpose of this dissertation, not all parts of the suggested approach may be applicable or relevant or necessarily applied in the suggested order. However, all parts of this suggested approach, except the last two indexed $F$ and $G$, has been considered in one way or another in this dissertation.

\subsection{Suggestions for future work}

In many planning situations there are fixed costs and variable costs to consider and to simplify; only the largest and crucial ones are most likely involved. For some companies it is the labour cost that is the most important, whereas for others it is the processing time or machinery cost in terms of utilised time in an expensive resource with presumably a high capital cost. In case energy costs are considered important, they should thus most likely already be included in the planning process or assigned some strategic momentum, yet that turns out to not always be the case in practice. The planning problem in process industries is because of their energy intensity very interesting in this context. Energy supply is in this dissertation considered as the main source for workforce in process industries. Hence, whereas a labour intense manufacturing industry chooses factory location due to labour costs, one might wonder what it would take for process industries to make similar choices due to energy costs. Of course, most process industries cannot move their facilities as easy as other manufacturing companies due to their process equipment, which makes them more dependent on regional conditions such as: distance to raw materials and distance to markets, but also in terms of energy constraints and opportunities. In this area there are thus plenty of research opportunities that could be focused on, however it is easy to wish for too much and list up too many questions. In order to narrow down and remain focused, the tooth fairy thus gives me only three wishes, and one of them is formulated in the first proposed Future Research Question (FRQ):

FRQ 1. How can process industries, or other energy intensive industries, by managerial means, utilize the regional conditions of their location?

There is also a presumed lack of planning support for process industries in general. Enterprise Resource Planning (ERP) systems that normally are standardised enough to fit ordinary manufacturing companies often fit less well or not at all in the more special process industry. In this context it is also interesting to further investigate how lead time reductions can be achieved, and/or if a changed strategy on how inventory is used as buffers can increase flexibility and availability. As such one might wonder if there are planning processes that could be standardised for process industries in general, leading to the next Future Research Question: 
FRQ 2. How can planning software be developed in order to fit the conditions of process industries more in general?

Given that the contributions in this dissertation are also very unique for each specific case there is also issues of generalizability to consider regarding how energy issues could be included in planning processes from a more general context. Another problem that also arises is the issue about robustness and how planning models can become more reliable in such context. This is all formulated in the third Future Research Question:

FRQ 3. How can planning processes in general become more robust and simultaneously more comprehensive, considering a broader scope where not only energy issues but also other environmental issues can be involved?

For the industry, most success is about knowing what you do, knowing what you want to do, and to do the best out of it. I would therefore like to put out three memories, statements, or perhaps more of recommendations for all, but utmost the energy intensive, process industries out there:

- Great improvements can be achieved with only managerial means without requiring large investments. Find them, analyse them, and consider the options!

- Locate your largest energy flows and find out how to save both energy and increase profitability by doing things differently. Business as usual is not always the best solution!

- Make your strategic decisions already today on how to stay long term competitive beyond tomorrow! 


\section{References}

APICS (2008) "APICS Dictionary: The standard for excellence in the operations management profession", Twelfth Edition, APICS The Association for Operations Management, Chicago, Illinois. ISBN: 1-55822-199-9

Arivalagan, A., Raghavendra, B.G. and Rao, A.R.K. (1995) "Integrated energy optimization model for a cogeneration based energy supply-system in the process industry", International Journal of Electrical Power \& Energy Systems, Vol. 17, No. 4, pp. 227-233. http://dx.doi.org/10.1016/0142-0615(95)00037-Q

Ashayeri, J., Heuts, R.J.M., Lansdaal, H.G.L. and Strijbosch, L.W.G. (2006) "Cyclic productioninventory planning and control in the pre-Deco industry: A case study", International Journal of Production Economics, Vol. 103, No. 2, pp 715-725.

http://dx.doi.org/10.1016/j.ijpe.2006.02.001

Bakhrankova, K. (2010) "Decision support system for continuous production", Industrial Management \& Data Systems, Vol. 110, No. 3-4, pp. 591-610. http://dx.doi.org/10.1108/02635571011039043

Bengtsson, C., Karlsson, M., Berntsson, T. and Söderström, M. (2002) "Co-ordination of pinch technology and the MIND method - applied to a Swedish board mill", Applied Thermal Engineering, Vol. 22, No. 2, pp. 133-144. http://dx.doi.org/10.1016/S1359-4311(01)00080-1

Bertrand, W.M. and Fransoo, J.C. (2002) “Operations management research methodologies using quantitative modeling", International Journal of Operations \& Production Management, Vol. 22, No. 2, pp. 241-264. http://dx.doi.org/10.1108/01443570210414338

Bolt, J. and J.L. van Zanden (2013) "The First Update of the Maddison Project; Re-Estimating Growth Before 1820", Maddison Project, Working Paper 4, Groningen, The Netherlands, URL: http://www.ggdc.net/maddison/maddison-project/data.htm accessed $29^{\text {th }}$ October 2014. 
Borgonovo, E. and Peccati, L. (2006) "The importance of assumptions in investment evaluation", International Journal of Production Economics, Vol. 101, No. 2, pp. 298-311. http://dx.doi.org/10.1016/j.ijpe.2005.01.009

Bredström, D., Lundgren, J.T., Rönnqvist, M., Carlsson, D. and Mason, A. (2004) "Supply chain optimization in the pulp mill industry - IP models, column generation and novel constraint branches", European Journal of Operational Research, Vol. 156, No. 1, pp. 2-22. http://dx.doi.org/10.1016/j.ejor.2003.08.001

Buffa, E.S. (1984) “Meeting the competitive challenge: Manufacturing Strategy for U.S. Companies", Dow (Jones \& Irwin), New York City, New York. ISBN: 9780256031249

Carlsson, D. and Rönnqvist, M. (2005) "Supply chain management in forestry-case studies at Sodra Cell AB", European Journal of Operational Research, Vol. 163, No. 3, pp. 589-616. http://dx.doi.org/10.1016/j.ejor.2004.02.001

Carlsson, D., D'Amours, S., Martel, A. and Rönnqvist, M. (2009) "Supply Chain Planning Models in the Pulp and Paper Industry", INFOR, Vol. 47, No. 3, 167-183. http://dx.doi.org/10.3138/infor.47.3.167

Chase, R.B., Jacobs F.R. and Aquilano, N.J. (2007) "Operations management for competitive advantage", Int. ed., McGraw-Hill, New-York City, New-York.

Christoffersen, L.B., Larsen, A. and Togeby, M. (2006) "Empirical analysis of energy management in Danish industry", Journal of Cleaner Production, Vol. 14, No. 5, pp. 516526. http://dx.doi.org/10.1016/j.jclepro.2005.03.017

Cook, S. (1971) "The Complexity of Theorem Proving Procedures", Proceedings of the third annual ACM symposium on Theory of computing. pp. 151-158. http://dx.doi.org/10.1145/800157.805047

Cooremans, C. (2011) "Make it strategic! Financial investment logic is not enough", Energy Efficiency, Vol. 4, No. 4, pp. 473-492. http://dx.doi.org/10.1007/s12053-011-9125-7

Cooremans, C. (2012) "Investment in energy efficiency: do the characteristics of investments matter?", Energy Efficiency, Vol. 5, No. 4, pp. 497-518. http://dx.doi.org/10.1007/s12053-012-9154-x

Dantzig, G.B. (1949) "Programming of Interdependent Activities: II Mathematical Model", Econometrica, Vol. 17, No. 3, pp. 200-211. http://dx.doi.org/10.2307/1905523

Dantzig, G.B. (1955) "Optimal Solution of a Dynamic Leontief Model with Substitution", Econometrica, Vol. 23, No. 3, pp. 295-302. http://dx.doi.org/10.2307/1910385

Dantzig, G.B. (1963) "Linear programming and extensions", Princeton University Press and the RAND Corporation, Princeton, New Jersey. ISBN: 9780691080000

Dennis, D.R. and Meredith, J.R. (2000) "An analysis of process industry production and inventory management systems", Journal of Operations Management, Vol. 18, pp 683699. http://dx.doi.org/10.1016/S0272-6963(00)00039-5 
Doll, C.L. and Whybark, D.C. (1973) "An Iterative Procedure for the Single-Machine MultiProduct Lot Scheduling Problem", Management Science, Vol. 20, No. 1, pp. 50-55. http://dx.doi.org/10.1287/mnsc.20.1.50

EIA (2013) "International Energy Outlook 2013", U.S. Energy Information Administration, Washington, District of Columbia, URL: http://www.eia.gov/forecasts/ieo/pdf/0484(2013).pdf accessed 13 ${ }^{\text {th }}$ August 2014.

Eisenhardt, K. (1989) "Building Theories from Case Study Research", Academy of Management, Vol. 14, No. 4, pp. 532-550. http://dx.doi.org/10.2307/258557

Finch, B.J. and Cox, J.F. (1987) "Planning and Control Systems Design: Principles and Cases for Process Manufacturers", American Production and Inventory Control Society (APICS), Falls Church, Virginia. ISBN: 9780935406948

Fine, C.H. and Hax, A.C. (1985) "Manufacturing strategy: a methodology and an illustration", Interfaces, Vol. 15, No. 6, pp. 28-46. http://dx.doi.org/10.1287/inte.15.6.28

Fisher, M. (1997) "What is the right supply chain for your product?", Harvard Business Review, Vol. 75, No. 2, pp. 105-116.

Fortune (2014) "GLOBAL 500 2014", Time Inc., New York City, New York, URL: http://fortune.com/global500 accessed $15^{\text {th }}$ August 2014.

Fransoo, J.C. (1992) "Demand management and production control in process industries", International Journal of Operations \& Production Management, Vol. 12, No. 7-8, pp. 187196. http://dx.doi.org/10.1108/EUM0000000001311

Fransoo, J.C. and Rutten, W.G.M.M. (1994) "A typology of production control situations in process industries", International Journal of Operations \& Production Management, Vol. 14, No. 12, pp. 47-57. http://dx.doi.org/10.1108/01443579410072382

Grubbström R.W. and Hultman, P. (1989) "Exergetic and inventory-theoretic aspects of energy-storage", Engineering Costs and Production Economics, Vol. 15, pp. 343-350. http://dx.doi.org/10.1016/0167-188X(89)90147-X

Grunow, M. and Günther, H.O. (2008) "Development of a decision support tool for supply network planning: A case study from the chemical industry", Operations Research and its Applications, Proceedings, Book Series: Lecture Notes in Operations Research, Vol. 8, pp. 18-24. ISBN: 978-7-5062-9288-7

Gunnarsson, H. and Rönnqvist, M. (2008) "Solving a multi-period supply chain problem for a pulp company using heuristics-An application to Sodra Cell AB", International Journal of Production Economics, Vol. 116, No. 1, pp. 75-94. http://dx.doi.org/10.1016/j.ijpe.2008.07.010

Gunnarsson, H., Rönnqvist, M. and Carlsson, D. (2006) "A combined terminal location and ship routing problem", Journal of the Operational Research Society, Vol. 57, No. 8, pp. 928938. http://dx.doi.org/10.1057/palgrave.jors.2602057 
Gunnarsson, H., Rönnqvist, M. and Carlsson, D. (2007) “Integrated production and distribution planning for Södra Cell AB", Journal of Mathematical Modelling and Algorithms, Vol. 6, No. 1, pp. 25-45. http://dx.doi.org/10.1007/s10852-006-9048-z

Gunnarsson, H., Rönnqvist, M. and Lundgren, J.T. (2004) "Supply chain modelling of forest fuel", European Journal of Operational Research, Vol. 158, No. 1, pp. 103-123. http://dx.doi.org/10.1016/S0377-2217(03)00354-0

Hammond, G.P. (2007) "Industrial energy analysis, thermodynamics and sustainability", Applied Energy, Vol. 84, No. 7-8, pp. 675-700. http://dx.doi.org/10.1016/j.apenergy.2007.01.002

Hayes, R.H. and Wheelwright, S.C. (1979a) "Link manufacturing process and product life cycles", Harvard Business Review, January-February 1979, pp. 133-140.

Hayes, R.H. and Wheelwright, S.C. (1979b) "The dynamics of process-product life cycles", Harvard Business Review, March-April 1979: pp. 127-136.

Hill, A. and Hill, T. (2009) "Manufacturing Operations Strategy: Text and Cases", $3^{\text {rd }}$ edition, Palgrave Macmillan, Hampshire, United Kingdom. ISBN: 978-0-230-52091-2

Hill, T. (2000) “Manufacturing Strategy: Text and Cases", $2^{\text {nd }}$ edition, Palgrave, Hampshire, United Kingdom. ISBN: 978-0-333-76222-6

IPCC (2014) "Fifth Assessment Report (AR5)", Intergovernmental Panel on Climate Change, Geneva, Switzerland, URL: http://www.ipcc.ch/ accessed $2^{\text {nd }}$ November 2014.

IVA (2006) "Ökad konkurrenskraft för svensk processindustri” (Improved competitiveness for Swedish process industry; in Swedish), Kungl. IngenjörsVetenskapsAkademien (The Royal Swedish Academy of Engineering Sciences (IVA); in Swedish), Stockholm, Sweden. ISBN: 91-7082-733-8

Johansson, J., Kylinger, M. and Waldemarsson, M. (2011) "Production planning in process industries", Presented at the NOFOMA 2011 Conference, held $9^{\text {th }}-10^{\text {th }}$ June 2011 in Harstad, Norway.

Johansson, J., Kylinger, M. and Waldemarsson, M. (2012) "Production planning in process industries", Working Paper: LIU-IEI-WP-12/0002, Department of Management and Engineering, Linköping University, Linköping, Sweden.

Kalenoja, H., Kallionpaa, E. and Rantala, J. (2011) "Indicators of energy efficiency of supply chains", International Journal of Logistics-Research and Applications, Vol. 14 No. 2, pp. 7795. http://dx.doi.org/10.1080/13675567.2010.551111

Kallrath, J. (2002a) "Combined Strategic and Operational Planning-An MILP Success Story in Chemical Industry", OR Spectrum, Vol. 24, No. 3, pp. 315-341. http://dx.doi.org/10.1007/s00291-002-0102-6

Kallrath, J. (2002b) "Planning and scheduling in the process industry", OR Spectrum, Vol. 24, pp. 219-50. http://dx.doi.org/10.1007/s00291-002-0101-7 
Kallrath, J. (2005) "Solving planning and design problems in the process industry using mixed integer and global optimization", Annals of Operations Research, Vol. 140, pp. 339-73. http://dx.doi.org/10.1007/s10479-005-3976-2

Karlsson, M. (2011) "The MIND method: A decision support for optimization of industrial energy systems - Principles and case studies", Applied Energy, Vol. 88, No. 3, pp. 577-589. http://dx.doi.org/10.1016/j.apenergy.2010.08.021

Karp, R.M. (1972) "Reducibility Among Combinatorial Problems", in Miller, R.E. and Thatcher, J.W. (editors), Complexity of Computer Computations: Proceedings of a Symposium on the Complexity of Computer Computations; The IBM Research Symposia Series, Plenum Press, New York City, New York, pp. 85-103.

Khouja, M. (1999) "The single-period (news-vendor) problem: literature review and suggestions for future research", Omega - International Journal of Management Science, Vol. 27, pp. 537-553. http://dx.doi.org/10.1016/S0305-0483(99)00017-1

King, P.L. (2009) "Lean for the Process Industries", Productivity Press, New York City, New York. ISBN: 978-1-4200-7851-0

Klugman, S., Karlsson, M. and Moshfegh, B. (2007) "A Scandinavian chemical wood-pulp mill. Part 1. Energy audit aiming at efficiency measures", Applied Energy, Vol. 84, No. 3, pp. 326-339. http://dx.doi.org/10.1016/j.apenergy.2006.07.003

Kondili, E., Pantelides, C.C., Sargent, R.W.H. (1993), “A general algorithm for short-term scheduling of batch operations-I. MILP formulation", Computers \& Chemical Engineering, Vol. 17, No. 2, pp. 211-227. http://dx.doi.org/10.1016/0098-1354(93)80015-F

Lenstra, H.W. (1983) "Integer programming with a fixed number of variables", Mathematics of operations research, Vol. 8, No. 8, pp. 538-548. http://dx.doi.org/10.1287/moor.8.4.538

Lidestam, H. and Rönnqvist, M. (2011) "Use of Lagrangian decomposition in supply chain planning", Mathematical and Computer Modelling, Vol. 54, No. 9-10, pp. 2428-2442. http://dx.doi.org/10.1016/j.mcm.2011.05.054

Loos, P. and Allweyer, T. (1998) "Application of production planning and scheduling in the process industries", Computers in Industry, Vol. 36, No. 3, pp. 199-208. http://dx.doi.org/10.1016/S0166-3615(98)00072-4

Lovins, A.B. (1976) "Energy Strategy - Road not taken", Foreign Affairs, Vol. 55, No. 1, pp. 6596.

Mallya, S., Banerjee, S. and Bistline, W.G. (2001) “A decision support system for production/distribution planning in continuous manufacturing", Decision Sciences, Vol. 32 No. 3, pp. 545-56. http://dx.doi.org/10.1111/j.1540-5915.2001.tb00971.x

Marshman, D.J., Chmelyk, T., Sidhu, M.S., Gopaluni, R.B. and Dumont, G.A. (2010) "Energy optimization in a pulp and paper mill cogeneration facility", Applied Energy, Vol. 87, No. 11, pp. 3514-3525. http://dx.doi.org/10.1016/j.apenergy.2010.04.023 
Mitroff, I.I., Betz, F., Pondy, L.R. and Sagasti F. (1974) “On Managing Science in the Systems Age: Two Schemas for the Study of Science as a Whole Systems Phenomenon", Interfaces, Vol. 4, No. 3, pp. 46-58.

Mohanty, R.P. and Deshmukh, S.G. (1998) “Managing green productivity: some strategic directions", Production Planning and Control, Vol. 9 No. 7, pp. 624-633. http://dx.doi.org/10.1080/095372898233614

O'Callaghan, P.W. and Probert, S.D. (1977) "Energy management", Applied Energy, Vol. 3, No. 2, pp. 127-138. http://dx.doi.org/10.1016/0306-2619(77)90024-1

Olhager, J. and Persson, F. (2006) "Simulating production and inventory control systems: a learning approach to operational excellence", Production Planning \& Control: The Management of Operations, Vol. 17, No. 2, pp. 113-127. http://dx.doi.org/10.1080/09537280500223921

Olhager, J., Rudberg, M. and Wikner, J. (2001) “Long-term capacity management: Linking the perspectives from manufacturing strategy and sales and operations planning", International Journal of Production Economics, Vol. 69, No. 2, pp. 215-225. http://dx.doi.org/10.1016/S0925-5273(99)00098-5

Paiva, R.P.O. and Morabito, R. (2009) "An optimization model for the aggregate production planning of a Brazilian sugar and ethanol milling company", Annals of Operations Research, Vol. 169, No. 1, pp. 117-130. http://dx.doi.org/10.1007/s10479-008-0428-9

PIC, 2014, "Process Industry Centre - providing knowledge for the process industry", Process Industry Centre, Lund, and Linköping, Sweden, URL:

http://www.processindustrycentre.se/, accessed $23^{\text {rd }}$ October 2014.

Plass, G.N. (1956), "The Carbon Dioxide Theory of Climate Change", Tellus, Vol. 8, No. 2, pp. 140-154. http://dx.doi.org/10.1111/j.2153-3490.1956.tb01206.x

Prahalad, C.K. and Hamel, G. (1990) "The Core Competence of the Corporation", Harvard Business Review, Vol. 68, No. 3, pp. 79-91.

Rudberg, M., Waldemarsson, M. and Lidestam, H. (2013) "Strategic Perspectives on Energy Management: A Case Study in the Process Industry", Applied Energy, Vol. 104, pp. 487496. http://dx.doi.org/10.1016/j.apenergy.2012.11.027

SCB (2014a) "Bränsleanvändning, terajoule (TJ), inom utvinning av mineral, tillverkningsindustri, terajoule (TJ) efter näringsgren SNI 2007, bränsletyp och år" (Use of fuel, Tera joule (TJ), within mineral extraction and manufacturing industry, Tera joule (TJ), divided into branch of activity according to SNI (Swedish Standard Industrial Classification) 2007, fuel type and year: in Swedish), Statistics Sweden, Stockholm, URL: http://www.statistikdatabasen.scb.se/pxweb/sv/ssd/START EN EN0113/BrAvnInd07 accessed $3^{\text {rd }}$ September 2014. 
SCB (2014b) “Pressmeddelanden från SCB (2014-02-27 09:30 Nr 2014:49) - Export och import av varor, januari-december 2013, i löpande priser" (Press releases from Statistics Sweden (2014-02-27 09:30 No. 2014: 49) - Export and import of goods, January to December 2013, current prices: in Swedish), Statistics Sweden, Stockholm, URL: http://www.scb.se/sv/Hitta-statistik/Statistik-efter-amne/Handel-med-varor-ochtjanster/Utrikeshandel/Utrikeshandel-med-varor/7223/7230/Behallare-for-Press/370478/ accessed $3^{\text {rd }}$ September 2014.

Schmalzried, D. (1998) "Cost-saving in the cement industry by optimization of production planning", ZKG International, Vol. 51, No. 10, pp. 578-583.

Shah, N. (2005) "Process industry supply chains: Advances and challenges", Computers \& Chemical Engineering, Vol. 29, No. 6, pp. 1225-1235. http://dx.doi.org/10.1016/j.compchemeng.2005.02.023

Skinner, W. (1969) "Manufacturing - missing link in corporate strategy", Harvard Business Review, Vol. 47, No. 3, May-June, pp. 136-145.

Stadtler H. and Kilger C. (2008) "Supply chain management and advanced planning concepts, models, software and case studies", $4^{\text {th }}$ edition, Springer-Verlag, Berlin Heidelberg, Germany. ISBN: 978-3-540-74511-2 http://dx.doi.org/10.1007/978-3-540-74512-9

Stratton, A. (1979) "Energy Forecasting", Omega - International Journal of Management Science, Vol. 7, No. 6, pp. 493-502. http://dx.doi.org/10.1016/0305-0483(79)90067-7

Swedish Energy Agency (2014) “Energitillförsel och energianvändning i Sverige 2012, TWh" (Energy supply and energy use in Sweden 2012; in Swedish), Swedish Energy Agency, Eskilstuna, Sweden, URL:

http://www.energimyndigheten.se/Global/Ny\%20statistik/Energibalans/databars7.pdf accessed $3^{\text {rd }}$ September 2014

Tang, C. and Tomlin, B. (2008) "The power of flexibility for mitigating supply chain risks", International Journal of Production Economics, Vol. 116, pp. 12-27. http://dx.doi.org/10.1016/j.ijpe.2008.07.008

Tari, M.H. and Söderström, M. (2002) "Optimisation modelling of industrial energy systems using MIND introducing the effect of material storage", European Journal of Operational Research, Vol. 142, No. 2, pp. 419-433. http://dx.doi.org/10.1016/S0377-2217(01)00299-5

Taylor, S.G., Seward, S.M. and Bolander, S.F. (1981a) "Why the Process Industries are different", Production and Inventory Management, Vol. 22, No. 4, pp. 9-24.

Taylor, S.G., Seward, S.M., Bolander, S.F. and Heard, R.C. (1981b) "Process Industry Production and Inventory Planning Framework: A Summary", Production and Inventory Management, Vol. 22, No. 1, pp. 15-33. 
Thollander, P. and Ottosson, M. (2010) "Energy management practices in Swedish energyintensive industries", Journal of Cleaner Production, Vol. 18, pp. 1125-1133. http://dx.doi.org/10.1016/j.jclepro.2010.04.011

Thollander, P., Mardan, N. and Karlsson, M. (2009) “Optimization as investment decision support in a Swedish medium-sized iron foundry - A move beyond traditional energy auditing", Applied Energy, Vol. 86, No. 4, pp. 433-440.

http://dx.doi.org/10.1016/j.apenergy.2008.08.012

Waldemarsson, M. (2012) “Energy and Production Planning for Process Industry Supply Chains", Linköping studies in science and technology, Thesis No. 1555, Linköping University Electronic Press, Linköping, Sweden.

ISBN: 978-91-7519-762-3

Waldemarsson, M. (2014) "Energy considerations in planning slab furnaces at a steel company - A case study at SSAB", Working Paper.

Waldemarsson, M., Lidestam, H. and Karlsson, M. (2013b) "How energy affects supply chain planning at a pulp company", Proceedings of the $22^{\text {nd }}$ International Conference on Production Research (ICPR22), held $28^{\text {th }}$ July $-1^{\text {st }}$ August 2013 in Iguassu Falls, Brazil.

Waldemarsson, M., Lidestam, H. and Karlsson, M. (2014a) “How energy price changes can affect supply chain planning at a pulp company", in review.

Waldemarsson, M., Lidestam, H. and Karlsson, M. (2014b) "Energy issues in supply chain and production planning in the steel industry - A case study at SSAB", Working Pape.

Waldemarsson, M., Lidestam, H. and Karlsson, M. (2014c) "Energy issues in supply chain and production planning in the steel industry - A case study at SSAB", in Grubbström, R.W, Hinterhuber, H.H., (Editors), PrePrints, Vol. 1, $18^{\text {th }}$ International Working Seminar on Production Economics, Innsbruck, Austria, $24^{\text {th }}-28^{\text {th }}$ February 24-28, 2014, pp. 489-501.

Waldemarsson, M., Lidestam, H. and Rudberg, M. (2012) "Including energy in supply chain planning at a pulp company", Proceedings of the Fourth International Conference on Applied Energy (ICAE2012), held $5^{\text {th }}-8^{\text {th }}$ July 2012 in Suzhou, China.

Waldemarsson, M., Lidestam, H. and Rudberg, M. (2013a) "Including energy in supply chain planning at a pulp company", Applied Energy, Vol. 112, pp. 1056-1065. http://dx.doi.org/10.1016/j.apenergy.2012.12.032

Waldemarsson, M., Rudberg, M. and Lidestam, H. (2010) "Energy management in process industries: current practices and future challenges", Proceedings of the EurOMA 2010 Conference, held $6^{\text {th }}-9^{\text {th }}$ June 2010 in Porto, Portugal.

Williams, H.P. (2009) "Logic and integer programming", International Series in Operations Research \& Management Science, Vol. 130, ISBN 978-0-387-92280-5 http://dx.doi.org/10.1007/978-0-387-92280-5 
Wolters, W.T.M., Lambert, A.J.D. and Claus, J. (1995) "Sequencing problems in designing energy efficient production systems", International Journal of Production Economics, Vol. 41, No. 1-3, pp. 405-410. http://dx.doi.org/10.1016/0925-5273(95)00057-7

Wood, M.K. and Dantzig, G.B. (1949) "Programming of Interdependent Activities: I General Discussion", Econometrica, Vol. 17, No. 3/4, pp. 193-199. http://dx.doi.org/10.2307/1905522

Voss, C., Tsikriktsis, N., Frohlich, M. (2002) "Case research in operations management", International Journal of Operations \& Production Management, Vol. 22, No. 2, 195-219. http://dx.doi.org/10.1108/01443570210414329

Yin, R. (2009) "Case Study Research: Design and Methods", $4^{\text {th }}$ edition, Sage, Thousand Oaks, California. ISBN: 978-1-4129-6099-1

Zuckerman, D. (1996) "On Unapproximable Versions of NP-Complete Problems", SIAM Journal on Computing, Vol. 25, No. 6, pp. 1293-1304. http://dx.doi.org/10.1137/S0097539794266407

Özdamar, L. and Birbil, S.I. (1999) "A hierarchical planning system for energy intensive production environments", International Journal of Production Economics, Vol. 58, No. 2, pp.115-129. http://dx.doi.org/10.1016/S0925-5273(98)00076-0 


\section{Suggestions for additional readings}

Aleklett, K., Höök, M., Jakobsson, K., Lardelli, M., Snowden, S. and Söderbergh, B. (2010) "The Peak of the Oil Age - Analyzing the world oil production Reference Scenario in World Energy Outlook 2008", Energy Policy, Vol. 38, No. 3, pp. 1398-1414. http://dx.doi.org/10.1016/j.enpol.2009.11.021

Atasu, A., Guide, V.D.R. and Van Wassenhove, L.N. (2008) "Product reuse economics in closed-loop supply chain research", Production and Operations Management, Vol. 17, No. 5, pp. 483-496. http://dx.doi.org/10.3401/poms.1080.0051

Berry, W.L., Hill, T. and Klompmaker, J.E. (1995) "Customer driven manufacturing", International Journal of Operations \& Production Management, Vol. 15 No. 3, pp. 4-15. http://dx.doi.org/10.1108/01443579510080517

Bloemhof-Ruwaard, J.M., Wassenhove, L.N., Gabel, H.L. and Weaver, P.M. (1996)

"Environmental life cycle optimization model for the European pulp and paper industry", Omega - International Journal of Management Science, Vol. 24, No. 6, pp. 615-629. http://dx.doi.org/10.1016/S0305-0483(96)00026-6

Bollapragada, S., Owens, B. and Taub, S. (2011) "Practice Summaries: An Optimization Model to Support Renewable Energy Investment Decisions", Interfaces, Vol. 41, No. 4, pp. 394395. http://dx.doi.org/10.1287/inte.1110.0560

Borges, A. R. and Antunes, C. H. (2003) “A fuzzy multiple objective decision support model for energy-economy planning", European Journal of Operational Research, Vol. 145, No. 2, pp. 304-316. http://dx.doi.org/10.1016/S0377-2217(02)00536-2

Bunse, K., Vodicka, M., Schonsleben, P., Brulhart, M. and Ernst, F.O. (2011) “Integrating energy efficiency performance in production management - gap analysis between industrial needs and scientific literature", Journal of Cleaner Production, Vol. 19, No. 6-7, pp. 667-679. http://dx.doi.org/10.1016/j.jclepro.2010.11.011 
Cai, Y.P., Huang, G. H., Yang, Z. F. and Tan, Q. (2009) "Identification of optimal strategies for energy management systems planning under multiple uncertainties", Applied Energy, Vol. 86, No. 4, pp. 480-495. http://dx.doi.org/10.1016/j.apenergy.2008.09.025

Capehart, B.L., Turner, C.T. and William, J.K. (2003) “Guide to Energy Management". 4th ed., The Fairmont Press, Inc., New York City, New York. ISBN: 0-88173-425-X

Dangayach, G.S., Deshmukh, S.G. (2001) “Manufacturing strategy: A literature review and some issues", International Journal of Operations \& Production Management, Vol. 21, No. 7, pp. 884-932. http://dx.doi.org/10.1108/01443570110393414

Erenguc, S.S., Simpson, N.C. and Vakharia, A.J. (1999) "Integrated production/distribution planning in supply chains: An invited review", European Journal of Operational Research, Vol. 115, No. 2, pp. 219-236. http://dx.doi.org/10.1016/S0377-2217(98)90299-5

Fleischmann, M., Bloemhof-Ruwaard, J.M., Dekker, R. van der Laan, E., van Nunen, J.A.E.E. and van Wassenhov, L.N. (1997) "Quantitative Models for Reverse Logistics: A review", European Journal of Operational Research, Vol. 103, pp. 1-17. http://dx.doi.org/10.1016/S0377-2217(97)00230-0

Friedlingstein, P., Houghton, R.A., Marland, G. et al. (2010) "Update on $\mathrm{CO}_{2}$ emissions", Nature Geoscience, Vol. 3, No. 12, pp. 811-812. http://dx.doi.org/10.1038/ngeo1022

Georgopoulou, E., Lalas, D. and Papagiannakis, L. (1997) “A multicriteria decision aid approach for energy planning problems: The case of renewable energy option", European Journal of Operational Research, Vol. 103, No. 1, pp. 38-54.

http://dx.doi.org/10.1016/S0377-2217(96)00263-9

Grau, R., Graells, M., Corominas, S., Espuna, A. and Puigjaner, L. (1996) “Global strategy for energy and waste analysis in scheduling and planning of multiproduct batch chemical processes", Computers \& Chemical Engineering, Vol. 20, No. 6-7, pp. 853-868. http://dx.doi.org/10.1016/0098-1354(95)00183-2

Grubbström, R.W. (2007) "An attempt to introduce dynamics into generalized exergy considerations", Applied Energy, Vol. 84, pp. 701-718.

http://dx.doi.org/10.1016/j.apenergy.2007.01.003

Grubbström, R.W. and Tang, O. (2000) "An Overview of Input-Output Analysis Applied to Production-Inventory Systems", Economic Systems Research, Vol. 12, No 1, pp. 3-25. http://dx.doi.org/10.1080/095353100111254

Güven, C. (1994) "Energy planning under import restrictions”, European Journal of Operational Research, Vol. 72, No. 3, pp. 518-528. http://dx.doi.org/10.1016/0377-2217(94)90420-0

Harris, I., Naim, M., Palmer, A., Potter, A. and Mumford, C. (2011) "Assessing the impact of cost optimization based on infrastructure modelling on $\mathrm{CO}_{2}$ emissions", International 
Journal of Production Economics, Vol. 131, No. 1, pp. 313-321.

http://dx.doi.org/10.1016/j.ijpe.2010.03.005

Hax, A.C. and Candea, D. (1984) "Hierarchical production planning", excerpt from

"Production planning and inventory management", Prentice-Hall, Englewood Cliffs, New Jersey, pp 393-404

Hopkins, M.S. (2009) "8 Reasons Sustainability Will Change Management (That You Never Thought of)", MIT Sloan Management Review, Vol. 51, No. 1, pp. 27-30.

Jacobs, F.R., Berry, W.L., Whybark, D.C. and Vollmann, T.E. (2011) “Manufacturing Planning and Control for Supply Chain Management", APICS/CPIM Certification Edition, McGrawHill, New York City, New York.

Jonsson, P., Kjellsdotter, L. and Rudberg, M. (2007) "Applying advanced planning systems for supply chain planning: three case studies", International Journal of Physical Distribution \& Logistics Management, Vol. 37, No. 10, pp. $816-834$. http://dx.doi.org/10.1108/09600030710848932

Kopelman, J.B. and Weaver, N.L. (1978) "Energy modeling as a tool for planning", Long Range Planning, Vol. 11, No. 1, pp. 25-33.

http://dx.doi.org/10.1016/0024-6301(78)90091-2

Lampret, M., Bukovec, V., Paternost, A., Krizman, S., Lojk, V. and Golobic, I. (2007) "Industrial energy-flow management", Applied Energy, Vol. 84, No. 7-8, pp. 781-794. http://dx.doi.org/10.1016/j.apenergy.2007.01.009

Mann, M.E., Bradley, R.S. and Hughes, M.K. (1998) “Global-scale temperature patterns and climate forcing over the past six centuries", Nature, Vol. 392, No. 6678 pp. 779-787. http://dx.doi.org/10.1038/33859

Markevich, A. (2009) "The Evolution of Sustainability", MIT Sloan Management Review, Vol. 51 , No. 1 , pp. $13-14$

McMahan, W.L. and Roach P.A. (1982) "Site Energy Optimization, A Math Programming Approach", Interfaces, Vol. 12, No. 6, pp. 66-82. http://dx.doi.org/10.1287/inte.12.6.66

Mitropoulos, C.S. and Samouilidis, J.E. (1983) “A model for forecasting energy economic systems", Omega - International Journal of Management Science, Vol. 31, No. 5, pp. 447455. http://dx.doi.org/10.1016/0305-0483(83)90037-3

Neto, J.Q.F., Walther, G., Bloemhof, van Nunen, J.A.E.E. and Spengler, T. (2009) “A methodology for assessing eco-efficiency in logistics networks", European Journal of Operational Research, Vol. 193, No. 3, pp. 670-682. http://dx.doi.org/10.1016/j.ejor.2007.06.056

O'Brien, C. (2002) "Global manufacturing and the sustainable economy", International Journal of Production Research, Vol. 40, No. 14, pp. 3867-3877. http://dx.doi.org/10.1080/00207540210157169 
Olhager, J. and Rudberg, M. (2002) "Linking manufacturing strategy decisions on process choice with manufacturing planning and control systems", International Journal of Production Research, Vol. 40, No. 10, pp. 2335-2351.

http://dx.doi.org/10.1080/00207540210131842

Ordorica-Garcia, G., Elkamel, A., Douglas, P.L., Croiset, E. and Gupta, M. (2008) “Energy optimization model with $\mathrm{CO}_{2}$-emission constraints for the Canadian oil sands industry", Energy \& Fuels, Vol. 22, No. 4, pp. 2660-2670. http://dx.doi.org/10.1021/ef700770n

Rath-Nagel, St. and Voss, A. (1981) "Energy models for planning and policy assessment", European Journal of Operational Research, Vol. 8, No. 2, pp. 99-114. http://dx.doi.org/10.1016/0377-2217(81)90249-6

Rosen, M.A. and Dincer, I. (2003) "Exergy-cost-energy-mass analysis of thermal systems and processes", Energy Conversion and Management, Vol. 44, No. 10, pp. 1633-1651. http://dx.doi.org/10.1016/S0196-8904(02)00179-6

Rudberg, M. and Cederborg, O. (2011) "APS for tactical planning in a steel processing company", Industrial Management and Data Systems, Vol. 111, No. 3-4, pp. 608-628. http://dx.doi.org/10.1108/02635571111133579

Rudberg, M. and Olhager, J. (2003) "Manufacturing networks and supply chains: an operations strategy perspective", Omega - International Journal of Management Science, Vol. 31, No. 1, pp. 29-39. http://dx.doi.org/10.1016/S0305-0483(02)00063-4

Rudberg, M. and Thulin, J. (2009) "Centralised supply chain master planning employing advanced planning systems", Production Planning and Control, Vol. 20, No. 2, pp. 158-167. http://dx.doi.org/10.1080/09537280802705047

Schonberger, R.J. (1986) "World Class Manufacturing: The Lessons of Simplicity Applied", Free Press, New York City, New York.

Schwarz, J., Beloff, B. and Beaver, E. (2002) "Use sustainability metrics to guide decisionmaking", Chemical Engineering Progress, Vol. 98, No. 7, pp. 58-63.

Shah, R. and Ward, P.T. (2003) "Lean manufacturing: context, practice bundles, and performance", Journal of Operations Management, Vol. 21, No. 2, pp. 129-149. http://dx.doi.org/10.1016/S0272-6963(02)00108-0

Stern, N. (2008) "The economics of climate change", American Economic Review, Vol. 98, No. 2, pp. 1-37. http://dx.doi.org/10.1257/aer.98.2.1

Stock, J.R. and Boyer, S.L. (2009) "Developing a consensus definition of supply chain management: a qualitative study", International Journal of Physical Distribution \& Logistics Management, Vol. 39, No. 8, pp. 690-711. http://dx.doi.org/10.1108/09600030910996323

Tang, O. and Grubbström, R.W. (2006) “On Using Higher-Order Moments for Stochastic Inventory Systems", International Journal of Production Economics, Vol. 104, pp. 454-461. http://dx.doi.org/10.1016/j.ijpe.2005.03.004 
Thierry, M., Salomon, M., Van Nuene, J. and Van Wassenhove, L. (1995) "Strategic Issues in Product Recovery Management", California Management Review, Vol. 37, No 2, pp. 114135.

Thollander, P., Danestig M., Rohdin P. (2007) “Energy policies for increased industrial energy efficiency: Evaluation of a local energy programme for manufacturing SMEs", Energy Policy, Vol. 35, No. 11, pp. 5774-5783. http://dx.doi.org/10.1016/j.enpol.2007.06.013

Trenberth, K.E., Fasullo, J.T., Kiehl, J. (2009) “Earth's Global Energy Budget”, American Meteorological Society, Vol. 90, No. 3, pp. 311-323. http://dx.doi.org/10.1175/2008BAMS2634.1

Van Gool, W. (1987) "The value of energy carriers", Energy, Vol. 12, No. 6, pp. 509-518. http://dx.doi.org/10.1016/0360-5442(87)90010-7

Van Wezel, W., Van Donk, D.P. and Gaalman, G. (2006) "The planning flexibility bottleneck in food processing industries", Journal of Operations Management, Vol. 24, No. 3, pp. 287300. http://dx.doi.org/10.1016/j.jom.2004.11.001 



\section{Papers}

The articles associated with this thesis have been removed for copyright reasons. For more details about these see:

http://urn.kb.se/resolve?urn=urn:nbn:se:liu:diva-112289 



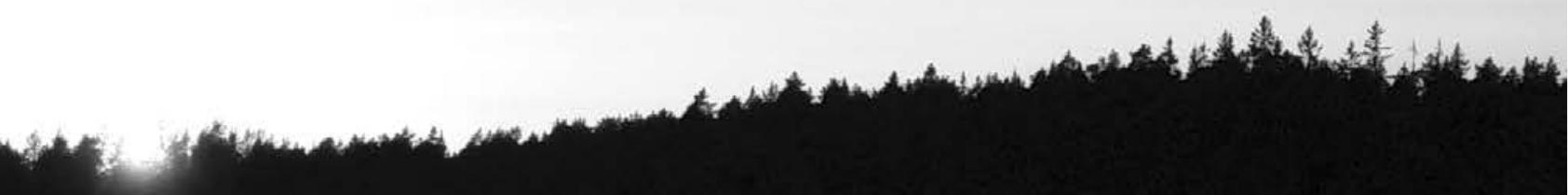

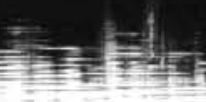




\section{Postface}

What is true knowledge? For our ancestors some million years ago it was more of a monkeysee monkey-do procedure where experiences easily fell into oblivion after a while. At some point in history our ability to communicate and exchange experience nevertheless improved. From the moment in history where the experience and lessons learnt by one generation passed on to the next, we humans started to accumulate knowledge. As such, one of our greatest heritages is the knowledge achieved by previous generations, a heritage we should carefully value, improve, and pass on to future generations. It is hence one of the cornerstones in the rise of our civilizations.

Research is one of many parts of the improvement process of inherited knowledge. It is also a process in which one can critically review and reflect upon what others have learnt and experienced. A reflection of the content of this dissertation could be rather subjective but also critical and question whether the scope is too broad or too narrow, if there are parts missing or if some parts diverge in focus, etcetera, and etcetera. The discussion could thus be long and equally important as focusing on what has been done and achieved. However, although some changes on the way in the research process have occurred and that some minor parts have taken a slightly different direction than what was originally proposed and expected, as supposed being common in long term projects, I would still say that the main direction and aim of my work has been rather steady and focused. The goal of what I want to achieve is something that has been in my mind since the beginning of this research, and should thus strengthen the validity and reliability of the sum of the research accomplished.

From an economic point of view, the importance of process industries and their position early in the value chain of consumer goods is a reality not to be neglected. Our entire economy seems highly dependent on the growth of consumption. A relevant question is therefore if consumption can be increased whereas finite resources decrease. To manage industry towards productivity and at the same time do more with less, is hence a huge challenge. Due to the resource intensity this challenge has a great impact on how process industries should be managed. There are a lot of managerial methods for improving process industry management, and some of them: planning of production and supply chain, stand in the focus of this dissertation. How this management should adopt to the economy we practice is a part of the roadmap for the success of its applicability. How our economy function, the reason why interest rates increases or decreases, why money changes its value over time, and why the customer pay a price in relation to the value achieved, hence build the ground rules for the practice of management. The cost of energy is very often motivation enough to enlighten the managerial complexity with energy issues in production or manufacturing environments. However, we should also put a high importance on the energy issue in general, considering that the current global energy use, through climate change, in worst case endangers the future of our species and other life at our planet. Yet, we should also be aware that improvements do not come through wishful thinking alone, since 
suggested improvements must also be prosperous and profitable for decision makers to consider. A lot can perhaps be achieved through non-profit organisations and their good will to create a better world, but most energy use has an economic side often linked to corporate profit maximization, where the choice is often as simple as it is cheap.

Nevertheless, if anything is possible, the only thing necessary is the willingness to imagine the difference, trying to change, and aiming for the better. It is questionable whether or not our view on our energy supply and the true value of the workforce it provides have been entirely fair and square since the discovery of fossil fuels. By definition, output of work (that is not intellectual work) from a system can actually be measured in the amount of energy. In the old days most work was performed by manpower or domesticated animals. It took then a person eight hours to perform the physical work similar to what can be achieved by one $\mathrm{kWh}$ of electricity. As such, it takes more than a week for a person to perform the physical work one otherwise can buy for a US dollar at the electricity market today. Yet, energy is considered expensive for many of us. But then why is it that a lot of the energy we use never create any real value and just ends up as waste? One might therefore wonder if there isn't something fundamentally wrong with our view, pricing, and expectations on our energy system; the system that not only provides workforce for our industries, but also washes our clothes, heats our homes, and transports us between cities. Not saying that there is anything wrong with all the good things our energy system provides us with, and the prosperity it brings to make our daily lives easier. The questionable thing is rather how we use our energy system, and what we feed it with.

As a final remark, I would like to make a note dedicated to the research community out there. This dissertation describes the process I have been going through in trying to become one of you, and can be seen as my driving licence to explore deeper into the world of science. Some of the results provided might be more worth or applicable than others, and derived using methods preferred more by some than others. I have learned to keep an open mind when tackling a problem, and doing so I have not been afraid to try new approaches that for some might be viewed upon as off-stream and unorthodox. I have also learned to not blindly rely upon the research of others and I suppose others do the same. The results in this dissertation are maybe not perfect and the methods used could probably be improved in some dimensions. It has perhaps not even reached the limitations of my own knowledge and skills or the expertise of my co-workers. I therefore ask myself if the current status of my work is able to reach for my own satisfaction, and I must say that much more can be done in the wake of this dissertation. Yet, by relying on numbers, logical explanations, the methods I feel comfortable with, and to some extent also pure common sense, I argue to comprehend the feasibility of the solutions and suggestions provided. It is not rocket science I present and I do not aim for achieving major scientific breakthroughs comparable to the achievements of the scientific giants of our history. Nevertheless, a line needs to be drawn to distinguish what is good enough at the moment, and to determine that the research is mature enough to defend in its current form. Despite various degrees of dissatisfaction that might occur, 
mostly referring to my own, I however believe that this dissertation can contribute to the evolution of the research community and to some extent move some of its frontiers. Hence, I hope I have contributed with a small puzzle-piece of knowledge in the large picture, but perhaps more importantly, also with some inspiration for innovative imagination. Doing so, I would be more than happy to just provide new ideas that hopefully could spin-off additional improvements in the directions I am pointing out. Just give it a thought, if no one would ever be satisfied, no new ideas would ever be published and our planet Earth would still be viewed upon as the centre of our solar system as well as flat in our minds. 
"To know that we know what we know,

and to know that we do not know what we do not know, that is true knowledge."

(Nicolaus Copernicus, $1473-1543$ ) 